\title{
Articles
}

\section{The Uneasy Case for the Priority of Secured Claims in Bankruptcy}

\author{
Lucian Arye Bebchuk ${ }^{\dagger}$ and Jesse M. Fried ${ }^{\dagger \dagger}$
}

\section{CONTENTS}

I. INTRODUCTION $\ldots \ldots \ldots \ldots \ldots \ldots \ldots \ldots \ldots \ldots \ldots$. . . . . . . . . 859

II. TOWARD RECONSIDERATION OF THE PRIORITY OF

SECUREd Claims IN BANKRUPTCY . . . . . . . . . . . . . . . 867

A. The General Prohibition Against Nonconsensual

Subordination ..................... 868

B. Value Transfer and Efficiency ................ 870

C. Would Adopting a Partial-Priority Rule Be a

Radical Change? ................... 871

III. THE PRIORITY-INDEPENDENT VALUE OF SECURITY INTERESTS $\ldots . .872$

A. The Problem of Borrower Misbehavior . . . . . . . . . 873

B. The Priority-Independent Benefits of Security Interests . . . . 875

C. The Priority-Independent Costs of Security Interests . . . . . 877

D. The Relative Value of Covenants ............. 878

$\dagger$ Professor of Law, Economics, and Finance, Harvard Law School.

t† John M. Olin Research Fellow in Law and Economics, Harvard Law School. For valuable suggestions, we would like to thank Barry Adler, Doug Baird, Andrew Guzmàn, Louis Kaplow, Ken Klee, Amir Licht, Lynn LoPucki, Mark Roe, George Triantis, Elizabeth Warren, and workshop participants at Harvard Law School, the University of Pennsylvania Law School, and the 1994 American Law and Economics Conference. We would also like to thank Rishi Ganti, Kevin Lapidus, and Liza Vertinsky for helpful research assistance. For financial support, both authors are grateful to the John M. Olin Center for Law, Economics and Business at Harvard Law School. Lucian Bebchuk also benefited from the financial support of the National Science Foundation and from the hospitality of the Tel Aviv Faculty of Law during his visits to Tel Aviv University. 
IV. THE INCENTIVE TO USE SECURITY INTERESTS

UNDER FULL PRIORITY . . . . . . . . . . . . . . . . . . 880

A. The Loan Contract Between Firm and Creditor ......... 880

B. The Easy Case for Full Priority in a World with Perfectly Adjusting Creditors ................... 881

C. The Presence of Nonadjusting Creditors . . . . . . . . 882

1. Private Involuntary Creditors . . . . . . . . . . . . 882

2. Government Tax and Regulatory Claims . . . . . . . . 884

3. Voluntary Creditors with Small Claims . . . . . . . 885

4. Prior Voluntary Creditors ................ 887

D. Full Priority and the Decision to Create a Security Interest .. 891

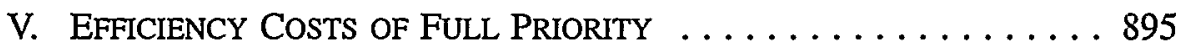

A. The Use of Inefficient Security Interests . . . . . . . . . 896

B. Distorted Choice Between Security Interests and Covenants .. 897

C. Distorted Investment and Precaution Decisions . . . . . . . 898

D. Suboptimal Use of Covenants ............... 900

E. Suboptimal Enforcement Efforts ............... 902

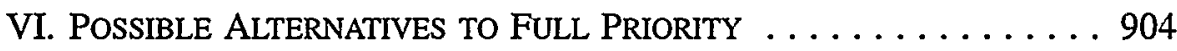

A. The Adjustable-Priority Rule ... . . . . . . . . . . 905

B. The Fixed-Fraction Priority Rule ................ 909

C. The Existing Erosion of Priority . . . . . . . . . . 911

VII. The Cost ANd EFfectiveness of a Partial-PRIORITy RUle . . 913

A. The Efficiency Costs of Partial Priority . . . . . . . . 913

1. Increased Information-Acquisition Costs ...........9914

2. Increased Cost of Coordinating Monitoring Efforts Among Creditors ............... 915

3. Reduced Financing for Desirable Activities . . . . . . 917

B. Some Relevant Empirical Evidence .............. 921

C. Enforcement of Partial Priority . . . . . . . . . . . 923

1. "Opting Out" of Bankruptcy . . . . . . . . . . . . 924

2. Using Lease Arrangements to Evade Partial Priority . . . 926

VIII. FuRTHER CONSIDERATIONS CONCERNING THE DESIRABILITY OF PARTIAL PRIORITY . . . . . . . . . . . . . . . . . . . . 929

A. Learning from the Past Behavior of U.S. Firms . . . . . . . 929

B. Leaving the Priority Rule to Private Ordering ......... 930

C. Fairness and Bargain Considerations ............ 931

D. Freedom of Contract Concerns ............... 932

IX. Conclusion $\ldots \ldots \ldots \ldots \ldots \ldots \ldots \ldots \ldots \ldots \ldots \ldots \ldots \ldots \ldots$ 


\section{INTRODUCTION}

This Article challenges the desirability of a fundamental and longstanding feature of bankruptcy law: the principle that a secured creditor is entitled to receive the entire amount of its secured claim-the portion of its bankruptcy claim that is fully backed by collateral-before any unsecured claims are paid. ${ }^{1}$ There is a widespread consensus among legal scholars and economists that the rule of according full priority to secured claims is desirable because it promotes economic efficiency. The analysis we offer demonstrates that, contrary to this conventional view, the efficiency case for full priority is at best problematic. We find that according full priority to secured claims leads to distortions in the arrangements negotiated between commercial borrowers and their creditors, which in turn generate a number of inefficiencies. Our analysis indicates that these inefficiencies could be reduced or eliminated by according only partial priority to secured claims, and that a rule of partial priority therefore may well be superior to the rule of full priority from the perspective of efficiency. Accordingly, the Article offers two rules of partial priority that should be considered as possible alternatives to the rule of full priority.

In a secured transaction, the borrower gives the creditor a security interest in specified property of the borrower that, if the borrower defaults, permits the creditor to take possession of the property in partial or full satisfaction of the debt. $^{2}$ The practice of taking a security interest in a borrower's property, which has ancient origins, ${ }^{3}$ continues to be widespread: Although there is no comprehensive source of information on secured commercial lending, the available data suggest that a substantial percentage of total U.S. business debt is secured. ${ }^{4}$ In the United States, large, publicly traded firms tend not to

1. We follow the U.S. Bankruptcy Code in using the term "secured claim" to refer to the portion of a creditor's bankruptcy claim that is fully backed by collateral and the term "unsecured claim" to refer to the part of a creditor's claim that is not backed by any collateral. See 11 U.S.C. $\$$ 506(a) (1994). The principle that secured claims are to be paid in full before any unsecured claims are paid is embodied in the "adequate protection" provisions of the U.S. Bankruptcy Code, see infra note 14 and accompanying text, and reflected in the rules of many other banknuptcy systems, see, e.g., Jochen Drukarczyk, Secured Debt, Bankruptcy, and the Creditors' Bargain Model, 11 INT'L REV. L. \& ECON. 203 (1991) (Germany); R.M. Goode, Is the Law Too Favourable to Secured Creditors?, 8 CANADIAN BUS. L.J. 53 (1984) (United Kingdom and Canada). See generally INTERNATIONAL CORPORATE INSOLVENCY LAW (Dennis Campbell ed., 1992) (surveying insolvency laws of various countries).

2. Although the term "security interest" is often used to describe a lien against personal property and the term "mortgage" generally refers to a lien against real property, we follow the U.S. Bankruptcy Code in using the term "security interest" to refer to any type of consensual lien. See 11 U.S.C. § 101(51) (1994).

3. See Goode, supra note 1, at 53. For a discussion of the evolution of security interests in the United States, see Douglas G. Baird \& Thomas H. Jackson, Cases, Problems, AND Materials on Security INTERESTS IN PERSONAL PROPERTY 1-81 (1987).

4. See, e.g., Allen N. Berger \& Gregory F. Udell, Collateral, Loan Quality, and Bank Risk, $25 \mathrm{~J}$. MONETARY ECON. 21, 31 (1990) (finding that, in sample of bank loans from 1977 to 1988, 27\% of dollar volume of loans were secured); John D. Leeth \& Jonathan A. Scott. The Incidence of Secured Debt: Evidence from the Small Business Community, 24 J. Fin. \& Quantitative ANALYsis 379.379 (1989) (reporting that 1982 Interagency Task Force on Small Business Finance study found that almost $80 \%$ of dollar volume of large- and small-business loans were secured and that 1983 National Federation of 
borrow on a secured basis. ${ }^{5}$ Thus, most commercial secured debt in the United States is issued by small and medium-sized companies. ${ }^{6}$

Under state laws governing transactions in personal and real property, a security interest in favor of a lender becomes effective when credit is extended and certain procedural requirements are met. ${ }^{7}$ Unless the parties agree otherwise, the secured lender generally retains all of the baseline rights of an unsecured creditor with respect to the borrower. That is, if the borrower defaults on the terms of the loan agreement, the secured lender may seek to reduce its claim to judgment, and then instruct an agent of the court to enforce the judgment against any of the debtor's property. As a secured creditor, the lender also enjoys two additional rights: a "repossessory right" and a state-law "priority right." In the event of default, the "repossessory right" gives the lender a qualified right to take possession of the assets covered by the security interest without resorting to judicial process. ${ }^{9}$ The state-law "priority right" gives the lender a right to these assets that is generally superior to the rights of other claimants, including purchasers, transferees, and other creditors. ${ }^{10}$ The state-law "priority right" is typically established when the lender "perfects" its security interest, either by taking possession of the assets or by

Independent Business study found that $78 \%$ of total volume of small-business loans were secured). It has been estimated that federally insured banks and savings associations, insurance companies, and finance companies hold approximately $\$ 1.9$ trillion of loans secured by real estate alone. See RONALD J. MANN, EXPLAINING THE PATTERN OF SECURED CREDIT FROM THE GROUND UP 1-2 nn.2-4 (Business, Law, and Economics Ctr., John M. Olin Sch. of Business, Wash. Univ. Working Paper BLE-95-10, 1995); see also Randal C. Picker, Security Interests, Misbehavior, and Common Pools, 59 U. CHI. L. REV. 645, 649-50 (1992) (estimating real property mortgage debt at $\$ 3.85$ trillion; automobile-backed debt at $\$ 285$ billion; and $\$ 96$ billion of other debt secured by personal property).

5. James R. Booth, Contract Costs, Bank Loans, and the Cross-Monitoring Hypothesis, $31 \mathrm{~J}$. FiN. ECON. 25, 40 n.10 (1992).

6. Robert E. Scott, A Relational Theory of Secured Financing, 86 COLUM. L. REV. 901,940 (1986).

7. In the United States, the creation of security interests in personal property is governed by Article 9 of the Uniform Commercial Code (UCC), a version of which has been adopted by every state. The creation of mortgages in real property is also governed by state law. See 3 RICHARD R. POWELL, POWELL ON REAL PROPERTY 37-45 to 37-127 (Patrick J. Rohon ed., 1994).

8. Deans Baird and Jackson have used the terms "property right" and "priority right" to describe the special rights accorded secured creditors. See BAIRD \& JACKSON, supra note 3, at 67. We prefer to use "repossessory right" rather than "property right," in part to stay clear of the debate over whether a secured creditor has property rights with respect to its security interest and what those rights, if any, might mean. Compare Steven L. Harris \& Charles H. Mooney, Ir., A Property-Based Theory of Security Interests: Taking Debtors' Choices Seriously, 80 VA. L. REV. 2021, 2047-66 (1994) (taking position that secured creditor has property interest in its security interest) with Lynn M. LoPucki, The Unsecured Creditor's Bargain, 80 VA. L. REV. 1887, 1952-54 (1994) (responding that property theory is not applicable to security interests) and James S. Rogers, The Impairment of Secured Creditors' Rights in Reorganization: A Study of the Relationship Between the Fifth Amendment and the Bankruptcy Clause, 96 HARV. L. REV. 973 (1983) (arguing that, by preselecting particular property to be used in satisfying its claim, secured creditor does not acquire property rights deserving greater constitutional protection than is accorded to contractual rights of unsecured creditor).

9. The rules concerning the repossession of personal-property collateral, including the prohibition against any repossession that would lead to a breach of the peace. are found in U.C.C. \$\$ 9-501 to 9-507 (1994).

10. See, e.g., id. $\$ \$ 9-201,9-301,9-312$. A person who in good faith buys personal-property collateral from another person in the business of selling goods of that kind will have rights in the collateral superior to those of the lender. See id. \$9-307. 
filing a financing statement in the appropriate public registries. ${ }^{11}$ The secured creditor can fully exercise both its "repossessory right" and its state-law "priority right" only outside of bankruptcy.

Our focus, however, is on the rights of the secured creditor when an insolvent debtor enters bankruptcy. ${ }^{12}$ Once the debtor enters bankruptcy, bankruptcy law "stays" the secured creditor from exercising its "repossessory right" to take possession of the collateral covered by the security interest. ${ }^{13}$ The secured creditor's state-law "priority right" in the collateral is also suspended. To compensate the secured creditor for the loss of its "priority right," bankruptcy law requires generally that, by the end of the proceeding, the creditor receive an amount equal to its secured claim. ${ }^{14}$ In practice, however, the compensation actually received by secured creditors is sometimes less than the value of their secured claims at the beginning of the bankruptcy process. ${ }^{15}$

Even though secured creditors do not always receive the full value of their secured claims in bankruptcy, they still retain a substantial advantage over general unsecured creditors, which have a claim to only those assets that remain after secured claims and the claims of certain priority unsecured creditors are paid or provided for. ${ }^{16}$ The effect of this priority scheme on the

11. The requirements for the perfection of a security interest in personal property are found in $i d$. \$\$ 9-302 to 9-306.

12. Most collective insolvency proceedings take place in federal bankruptcy courts. See ELIZABETH WARREN \& JAY LAWRENCE WeStBROOK, THE LAW OF DEBTORS aND CREDITORS 177 (2d ed. 1991). However, a substantial number of firms are liquidated outside of bankruptcy, either under state insolvency laws or without any insolvency proceedings. See Lynn M. LoPucki, A General Theory of the Dynamics of the State Remedies/Bankruptcy System, 1982 WIS. L. REV. 311, 311 (reporting that large percentage of businesses that close and fail to pay their debts fully do not enter federal bankruptcy). Although our analysis of the efficiency consequences of full priority applies regardless of the setting in which the bankrupt firm is liquidated or reorganized, the analysis assumes for ease of exposition that an insolvent debtor will (either voluntarily or involuntarily) enter bankruptcy. In Part VII, we consider the effect of the ability of firms to liquidate outside of bankruptcy on the desirability of implementing a partial-priority rule in bankruptcy.

13. See 11 U.S.C. \$ 362(a) (1994). However, the secured creditor can demand that the court lift the "stay" if its interest in the debtor's property is not "adequately protected." See infra note 14.

14. The secured creditor's "priority right" in the collateral is, in principle, protected by the "adequate protection" provisions of the U.S. Bankruptcy Code. These provisions require that a secured creditor whose "repossessory right" is stayed be given "adequate protection" during the bankruptcy proceeding in the form of either cash payments or substitute liens so that, at the end of the process, the creditor receives the full amount of its secured claim. See id. $\$ \$ 361-364$ (1994). The legislative history of these provisions makes it clear that their purpose was to respect the secured creditor's "priority right":

Secured creditors should not be deprived of the benefit of their bargain. . . . Though the creditor might not be able to retain his lien upon the specific collateral held at the time of filing, the purpose of [the provision] is to insure that the secured creditor receives the value for which he bargained.

S. REP. No. 989, 95th Cong., 2d Sess. 53 (1978). As explained infra Section VI.C, however, the actual treatment of secured claims in bankruptcy provides secured creditors with less than "adequate protection."

15. The erosion of the value of secured claims in the current bankruptcy system is described infra Section VI.C.

16. The U.S. Bankruptcy Code gives full priority (over general unsecured claims) to certain unsecured claims within the following categories: (1) postbankruptcy administrative claims, (2) claims arising after the commencement of an involuntary bankruptcy, (3) wage and other compensation-related claims, up to $\$ 4000$ per individual, (4) employee benefit claims, (5) claims of farmers and fishermen, (6) customer 
allocation of bankruptcy value among creditors is significant. If, as is usually the case, the business debtor is immediately or eventually liquidated, ${ }^{17}$ general unsecured creditors can expect to receive only a few cents on the dollar. ${ }^{18}$ Even in the relatively few cases where a business debtor successfully reorganizes under Chapter $11,{ }^{19}$ the mean recovery by general unsecured creditors is typically only $20 \notin$ to $30 \notin$ on the dollar. ${ }^{20}$

The principle of according full priority to secured claims in bankruptcy is firmly established in the law. ${ }^{21}$ And although some commentators have questioned the fairness of permitting a debtor to encumber its assets in favor of secured creditors at the expense of unsecured creditors, ${ }^{22}$ the predominant view of those who have examined full priority from an economic approach is that it is desirable to respect the state-law "priority right" of secured creditors to the greatest extent possible in bankruptcy. ${ }^{23}$ It is this view-sometimes

claims, up to $\$ 18,000$, (7) claims for alimony or child support, (8) government tax claims, and (9) claims of the FDIC and other financial regulatory agencies. 11 U.S.C. \$ 507(a) (1994). These priority claims are, in principle, subordinated to secured claims; all other unsecured claims then share pro rata in any remaining assets. See id. \$ 726(b).

17. The overwhelming majority of bankruptcies end in liquidation. See Douglas G. Baird, The Reorganization of Closely Held Firms and the "Opt Out" Problem, 72 WASH. U. L.Q. 913, 916 (1994); James J. White, Efficiency Justifications for Personal Property Security, 37 VAND. L. REv. 473, 482 (1984).

18. See, e.g., LoPucki, supra note 12 , at 311 (finding that $80 \%$ of liquidation cases studied involved no distribution to general creditors and that in remaining cases, general creditors received, on average, $4.5 \%$ per dollar); Michelle J. White, Bankruptcy Liquidation and Reorganization, in HANDBOOK OF MODERN FINANCE E7-1, E7-34 (Dennis E. Logue ed., 1995) (reporting that, in sample of 90 small firms that liquidated in bankruptcy, average payout rate to unsecured creditors was $4 \%$ ).

19. Following a Chapter 11 reorganization, the debtor firm continues operating as an ongoing enterprise. In exchange for their prebankruptcy claims, creditors typically receive some combination of cash, stock, and debt in the continuing business. See generally Douglas G. BAIRD \& THOMAS H. JACKSON, CASES, PROBLEMS, AND MATERIALS ON BANKRUPTCY 947-1129 (2d ed. 1990) (discussing reorganization under Chapter 11).

20. See, e.g., LoPucki, supra note 12, at 311 (finding that average payout promised-but not necessarily paid-to general unsecured creditors in reorganization cases was about $32 \propto$ per dollar). Even in successful Chapter 11 reorganizations of large, publicly traded corporations with relatively little secured debt, the average return to general unsecured creditors is less than $50 \notin$ on the dollar. See Lynn M. LoPucki \& William C. Whitford, Bargaining over Equity's Share in the Bankruptcy Reorganization of Large, Publicly Held Companies, 139 U. PA. L. REv. 125, 142 (1990). Results similar to these were found in a recent study of Canadian bankruptcy reorganizations. See Philippe Aghion et al., Improving Bankruptcy Procedure, 72 WASH. U. L.Q. 849, 867 n.30 (1994).

21. See BAIRD \& JACKSON, supra note 3, at 473. For a discussion of the treatment of secured claims in other bankruptcy systems, see INTERNATIONAL CORPORATE INSOLVENCY LAW, supra note 1.

22. Scholars critical of the ease with which a debtor can issue security interests that reduce the payment received by unsecured creditors in bankruptcy include Vern Countryman, Code Security Interests in Bankruptcy, 75 CoM. L.J. 269 (1970); Grant Gilmore, The Good Faith Purchase Idea and the Uniform Commercial Code: Confessions of a Repentant Draftsman, 15 GA. L. Rev. 605 (1981); LoPucki, supra note 8. However, these commentators' concerns about the fairness of according full priority to secured claims did not cause them to systematically study, as we do, the inefficiencies that arise from according priority to secured claims, or to consider either of the two alternatives to full priority that are presented in this Article.

23. The premise of most commentators writing on the subject of secured debt, including those taking an economic approach, has been that according full priority to secured claims is socially desirable. Much of the scholarly work of those writing from an economic perspective has thus focused on identifying the efficiency benefits of security interests and full priority. While there has been disagreement about the importance of the different benefits that have been identified and the validity of the different approaches 
described as the "creditors" bargain" theory ${ }^{24}$-that we challenge in this Article. ${ }^{25}$

We will show that a rule according full priority to secured claims in bankruptcy tends to reduce the efficiency of the loan arrangement negotiated between a commercial borrower and a potentially secured creditor. That is, full priority tends to reduce the total value captured by the borrower, the

that have been employed in this effort, the general consensus in the literature is that full priority should be accorded to secured claims in bankruptcy. Contributions in this area include Barry E. Adler, An EquityAgency Solution to the Bankruptcy-Priority Puzzle, 22 J. LEGAL STUD. 73 (I993); Richard L. Barnes, The Efficiency Justification for Secured Transactions: Foxes with Soxes and Other Fanciful Stuff, 42 KAN. L. REV. 13 (1993); James W. Bowers, Groping and Coping in the Shadow of Murphy's Law: Bankruptcy Theory and the Elementary Economics of Failure, 88 MICH. L. REV. 2097 (1990); F.H. Buckley, The Bankruptcy Priority Puzzle, 72 VA. L. REv. 1393 (1986); David Gray Carlson, On the Efficiency of Secured Lending, 80 VA. L. REV. 2179 (1994); Harris \& Mooney, supra note 8; Thomas H. Jackson \& Anthony T. Kronman, Secured Financing and Priorities Among Creditors, 88 YALE L.J. 1143 (1979); Alex M. Johnson, Jr., Adding Another Piece to the Financing Puzzle: The Role of Real Property Secured Debt, 24 LOY. L.A. L. REV. 335 (1991); Hideki Kanda \& Saul Levmore, Explaining Creditor Priorities, 80 VA. L. REv. 2103 (1994); Homer Kripke, Law and Economics: Measuring the Economic Efficiency of Commercial Law in a Vacuum of Fact, 133 U. PA. L. REv. 929 (1985); Leeth \& Scott, supra note 4; Saul Levmore, Monitors and Freeriders in Commercial and Corporate Settings, 92 YALE L.J. 49 (1982); Picker, supra note 4; Alan Scliwartz, The Continuing Puzzle of Secured Debt, 37 VAND. L. Rev. 1051 (1984) [hereinafter Schwartz, Continuing Puzzle]; Alan Schwartz, Security Interests and Bankruptcy Priorities: A Review of Current Theories, 10 J. LEgal STud. 1 (1981) [hereinafter Schwartz, Security Interests]; Alan Schwartz, Taking the Analysis of Security Seriously, 80 VA. L. REV. 2073 (1994) [hereinafter Schwartz, Taking]; Alan Schwartz, A Theory of Loan Priorities, 18 J. LEGAL STUD. 209 (1989) [hereinafter Schwartz, Theory]; Scott, supra note 6; Paul M. Shupack, Solving the Puzzle of Secured Transactions, 41 RuTGERS L. REv. 1067 (1989); Clifford W. Smith, Jr. \& Jerold B. Warner, Bankruptcy, Secured Debt, and Optimal Capital Structure: Comment, 34 J. FiN. 247 (1979); René M. Stulz \& Herb Johnson, An Analysis of Secured Debt, 14 J. FiN. ECON. 501 (1985); George G. Triantis, Secured Debt Under Conditions of Imperfect Information, 21 J. LEgal STud. 225 (1992) [hereinafter Triantis, Secured Debt]; Lawrence A. Weiss, Bankruptcy Resolution: Direct Costs and Violation of Priority of Claims, 27 J. FIN. ECON. 285 (1990); White, supra note 17; James J. White, The Recent Erosion of the Secured Creditor's Rights Through Cases, Rules and Statutory Changes in Bankruptcy Law, 53 Miss. L.J. 389 (1983) [hereinafter White, Recent Erosion]; James J. White, Work and Play in Revising Article 9, 80 VA. L. REV. 2089, 2089-90 (1994); George G. Triantis, Theoretical Observations on the Nature of Secured Debt (1989) (unpublished J.S.D. dissertation, Stanford Law School) [hereinafter Triantis, Theoretical Observations].

24. The term "creditors' bargain" was introduced by Dean Jackson to describe the set of bankruptcy rules that creditors would have bargained for had they been able to negotiate among themselves ex ante. See Thomas H. Jackson, Bankruptcy, Non-Bankruptcy Entitlements, and the Creditors' Bargain, 91 YALE L.J. 857,860 (1982). Jackson argued that, in such a hypothetical bargain, creditors would agree to the set of bankruptcy rules that were most efficient, which Jackson believed to be the set of rules giving creditors as much of each of their nonbankruptcy entitlements as possible. The "creditors' bargain" thus became shorthand for, among other things, the view that efficiency requires that secured claims be accorded the same priority in bankruptcy as they are accorded under state law.

25. Both the "creditors' bargain" theory and our analysis of the treatment of secured claims in bankruptcy focus on the division of value among creditors in bankruptcy. A similar but distinct issue is the optimal division of bankruptcy value between creditors (as a group) and shareholders. Under the currently prevailing rule of absolute priority, equityholders are to be paid nothing unless all creditors are paid or provided for in full. However, the rule of absolute priority is frequently violated in practice. See, e.g., Lucian Arye Bebchuk \& Howard F. Chang, Bargaining and the Division of Value in Corporate Reorganization, 8 J.L. ECON. \& ORGANIZATION 253, 254 (1992); Allan C. Eberhart et al., Security Pricing and Deviations from the Absolute Priority Rule in Bankruptcy Proceedings, 45 J. Fin. 1457, 1457 (1990); Julian R. Franks \& Walter N. Torous, An Empirical hnvestigation of U.S. Firms in Reorganization, $44 \mathrm{~J}$. FIN. 747, 748 (1989); LoPucki \& Whitford, supra note 20, at 149. Our analysis applies whether or not absolute priority is respected in bankruptcy. For simplicity, however, we assume throughout that equityholders receive nothing in bankruptcy unless all creditors' claims are fully paid or provided for. 
potentially secured creditor, and all other parties affected by the arrangement, which we assume to be the borrower's other creditors. ${ }^{26}$

Our analysis does suggest that the loan arrangement between a commercial borrower and a potentially secured creditor under the rule of full priority would be efficient in a hypothetical world in which the use of a security interest does not have distributional consequences for the borrower's other creditors. Assume that when a security interest is created, the amount owed to all other creditors changes in such a way as to offset the impact of the transaction on them, including the effect on them of permitting the recipient of the security interest to have a secured claim with full priority in bankruptcy. Under these circumstances, the creation of a security interest under full priority would never impose a negative externality on the other creditors, and a security interest could not, therefore, be used to divert value from these creditors. Consequently, a security interest would be chosen only if it were efficient. In this hypothetical world, efficiency would thus require giving full priority to the secured claim in the event of bankruptcy:

In the real world, however, the creation of a security interest under the rule of full priority has distributional consequences. In particular, under the rule of full priority, the creation of a security interest diverts value from creditors that do not "adjust" the size of their claims to take into account the effect of the loan transaction that creates the security interest, including the fact that any security interest given to the secured creditor subordinates their unsecured claims.

A firm will have many such "nonadjusting" creditors. The size of the claims of any tort creditors will not take into account the existence of a security interest encumbering the borrower's assets. Similarly, the size of government tax and regulatory claims will be fixed by statute without regard to the possibility that the claims may be subordinated by a secured claim in bankruptcy. There will also be nonadjusting creditors whose claims arise out of voluntary dealings with the borrower. Many creditors will have claims that are simply too small to justify the cost of taking the security interest into account when contracting with the borrower, and will thus be "rationally uninformed" about the borrower's financial structure. Finally, any contractual creditor that extends credit on fixed terms before a decision is made whether to create a particular security interest, and is therefore unable to adjust its claim to take into account the fact that the security interest is created, will be nonadjusting with respect to that security interest.

26. We adopt the assumption standard in the bankruptcy and secured-debt literature that externalities from arrangements between a borrower and a creditor impinge only on parties that would have claims against the borrower in bankruptcy. The analysis we offer would also apply if these arrangements do not systematically differ in their effects on parties that would not have such claims, or if according full priority to secured claims on balance imposes a negative externality on these parties. 
The fact that security interests may be used to transfer value from nonadjusting creditors under a full-priority rule means that security interests may be used even when they give rise to inefficiencies. As our analysis will demonstrate, the ability to use security interests to divert value from nonadjusting creditors tends to distort the borrower's choice of contractual arrangements with its creditors, giving rise to certain efficiency costs. In particular, we will show that the rule of providing full priority to secured claims may cause the use of inefficient security interests, distort the choice between the use of security interests and covenants in loan contracts, skew firms' investment and precaution decisions, and reduce the incentive of secured creditors to appropriately control their borrowers' behavior. ${ }^{27}$

It should be emphasized that the analysis we offer does not assume that the two categories of voluntary nonadjusting creditors described above-rationally uninformed creditors with small claims and creditors that lend before the decision regarding the security interest is made-are "victimized" by the creation of a security interest giving another creditor a secured claim. It would not affect our conclusion if all voluntary creditors extended credit on terms that reflected perfectly the expected risk of loss arising from the presence of secured claims so that, on average, no transfer of value from these creditors occurs. Nor does our analysis depend on the existence of tort or government claims; the problems we identify would still occur in a world without involuntary creditors, albeit to a lesser degree. Our analysis relies only on the fact that, with respect to every borrower, there invariably exist nonadjusting creditors, that is, creditors that do not adjust the size of their claims against the borrower when the borrower creates a security

27. To our knowledge, this Article provides the first systematic analysis of how full priority distorts a debtor's choice of contractual arrangements with its creditors, leading to the efficiency costs we identify. However, this Article is not the first to advance the argument that the rule of full priority has adverse efficiency consequences. It has Iong been recognized that according full priority to secured claims may permit inefficient projects to be financed or, under certain conditions, allow a firm to continue operating when it should be liquidated. See John Hudson, The Case Against Secured Lending, 15 INT'L REV. L. \& ECON. 47 (1995) (asserting that full priority may allow firm to continue operating inefficiently); Thomas H. Jackson \& Robert E. Scott, On the Nature of Bankruptcy: An Essay on Bankruptcy Sharing and the Creditors' Bargain, 75 VA. L. REV. 155, 169-73 (1989) (arguing that full priority may encourage eve-ofbankruptcy misbehavior by firm's secured creditor); Michelle J. White, Public Policy Toward Bankruptcy: Me-First and Other Priority Rules, 11 BELL J. ECON. 550, 552-61 (1980) (asserting that full priority may cause firms to overinvest or continue operating inefficiently). We will discuss these particular efficiency problems in Section VII.A when comparing the effects of full and partial priority on the ability of firms to finance desirable and undesirable activities. However, our analysis, unlike the analyses presented in these articles, seeks to identify the distortions and efficiency costs that occur under full priority whether or not the firm is in financial distress, and whether or not full priority permits inefficient projects to take place. Jackson \& Scott, supra, at 164-69, have also suggested that full priority may be inefficient if creditors prefer that the risk of default be spread among all creditors. But see David G. Carlson, Bankruptcy Theory and the Creditors' Bargain. 61 U. CIN. L. REV. 453, 479-91 (1992) (assessing critically Jackson and Scott's risk-sharing theory): Mark J. Roe. Commentary on "On the Nature of Bankruptcy: Bankruptcy. Priority, and Economics," 75 VA. L. REv. 219, 220-22 (1989) (same). In contrast to our more general analysis, which applies even under the standard assumption that commercial parties are risk-neutral, the Jackson and Scott analysis depends on particular assumptions about the distribution of risk preferences among creditors. 
interest in favor of another creditor. This alone is sufficient to give rise to the inefficiencies we identify.

Accordingly, we believe that full priority is unlikely to be the most efficient rule for allocating value between secured and unsecured creditors. We therefore will consider as alternatives to the rule of full priority two bankruptcy priority rules that would reduce or eliminate the inefficiencies we identify by according only partial priority to secured claims. The first partialpriority rule presented-the "adjustable priority rule"-would operate like the rule of full priority, except that the bankruptcy share of each nonadjusting creditor would be determined by treating the secured claims to which it could not adjust as unsecured claims. The effect of this rule, which would prevent a secured claim from subordinating the claims of any creditors that could not adjust to it, would be to transfer some bankruptcy value from secured creditors to nonadjusting creditors. ${ }^{28}$ The second partial-priority rule would treat a fixed fraction of every secured claim as an unsecured claim, rendering all secured creditors at least partially unsecured. This rule, the "fixed-fraction priority rule," is similar to a priority rule that was proposed in 1985 by the German Commission on Bankruptcy Law. ${ }^{29}$

Neither of the partial-priority rules presented would be superior to the rule of full priority in all respects. Any partial-priority rule would involve certain efficiency costs and create certain enforcement challenges. However, our preliminary analysis does suggest that the efficiency costs of a partial-priority rule might be relatively modest and that such a rule could be effective if implemented. Thus, there may well be a partial-priority rule that is superior to full priority from the standpoint of efficiency.

Our analysis also considers other issues related to the adoption of a mandatory partial-priority rule. We show that, if partial priority is preferable to full priority, the adoption of such a rule should not be left to private ordering. That is, borrowers should not be given the choice to opt into or out of such a rule. We also demonstrate that a mandatory partial-priority regime would be consistent with fundamental principles of contract law. We show that partial priority would give the secured creditor the benefit of its bargain and not be unfair. We also show that since the creation of a security interest in favor of a particular creditor under full priority transfers value from nonconsenting third parties, limiting the priority accorded to secured claims would not violate conventional notions of freedom of contract.

The Article is organized as follows: Part II offers a simple and intuitive explanation why the rule of full priority is problematic, and then explains why adoption of an explicit partial-priority rule would not be as radical a step as

28. The bankruptcy share of adjusting unsecured creditors would be the same as under full priority. See infra Part VI.

29. See infra notes $168-69$ and accompanying text. 
it might appear. Part III highlights an important preliminary point: The use of a security interest gives rise to many efficiency costs and benefits that do not depend on secured claims being accorded priority over unsecured claims in bankruptcy. In Part IV, we demonstrate that many creditors are "nonadjusting," and we show that the presence of nonadjusting creditors may lead to the use of inefficient security interests when secured claims are accorded full priority in bankruptcy. Part V describes five types of inefficiencies-one of which is the use of inefficient security interests-that arise under the rule of full priority. Part VI presents the two partial-priority rules that would reduce or eliminate these distortions. Part VII considers certain efficiency and effectiveness objections to a rule of partial priority in bankruptcy. Part VIII examines other considerations related to the adoption of a mandatory partialpriority rule.

\section{TOWARD RECONSIDERATION OF THE PRIORITY OF SECURED CLAIMS IN BANKRUPTCY}

The notion that a secured creditor is entitled to recover the full value of its collateral (up to the amount of its claim) whenever a borrower defaults on a secured loan permeates conventional thinking about the treatment of secured creditors in bankruptcy. The first two sections of this part therefore offer a brief and intuitive explanation why giving a secured creditor the full value of its collateral in bankruptcy is problematic. The third and last section then explains why the adoption of an explicit partial-priority rule would not be as radical a move as it might seem at first glance.

We first explain that full priority gives a borrower the power to subordinate the bankruptcy claims of nonconsenting unsecured creditors to that of another creditor. This stands in stark contrast to the general rule that a borrower may not lower the bankruptcy priority ranking of a creditor without its consent. We show that according secured claims full priority over unsecured claims is therefore in tension-rather than in harmony-with a fundamental principle of bankruptcy law.

Using basic economic intuition, we then explain why enabling a borrower to give one creditor priority over other creditors without their consent might create efficiency problems. In short, when it is possible for two parties to divert value from a third, nonconsenting party, the two parties will have an incentive to adopt arrangements that transfer value from the third party even if value is lost as a result of those arrangements. Since the rule of full priority allows a borrower and a potentially secured creditor to transfer value from nonconsenting creditors, it gives the two parties an incentive to adopt inefficient arrangements to accomplish that result. This is the source of the inefficiencies that we will show arise under full priority. And it is also the 
reason why it may well be desirable to limit a borrower's ability to transfer value in this manner by according only partial priority to secured claims.

Finally, we point out that, while adopting a rule of partial priority would lead to a substantial change in U.S. bankruptcy law, the current bankruptcy regime actually implements a de facto rule of partial priority: Although in principle secured claims are entitled to full priority over unsecured claims, a number of features of Chapter 11 reorganizations tend to erode the full priority of secured claims. The partial-priority rules we offer as alternatives to full priority would, of course, achieve partial priority differently than the current regime. However, the fact that we have actually been living in a world of partial priority for some time should help allay concerns that a rule of partial priority would disrupt commercial lending markets.

\section{A. The General Prohibition Against Nonconsensual Subordination}

One of the most important purposes of a bankruptcy system is to allocate the value of a bankrupt debtor's assets among its creditors. ${ }^{30}$ To accomplish this, rules must specify the bankruptcy entitlement of each creditor. The allocation scheme used in the United States and in many other countries gives ordinary creditors their pro rata share of any assets that remain after secured (and priority unsecured) creditors are paid. ${ }^{31}$ Therefore, in the absence of secured (or priority unsecured) creditors, ordinary creditors would share pro rata in the debtor's assets.

A fundamental feature of bankruptcy allocation rules is that they are mandatory. ${ }^{32}$ That is, a borrower may not circumvent the distribution rules by subordinating or reducing one creditor's bankruptcy claim in favor of another's. For example, under U.S. law, an ordinary unsecured creditor $C_{l}$ may not contract with the borrower for its claim to have priority in bankruptcy over that of another ordinary unsecured creditor $C_{2}$ without $C_{2}$ 's consent. ${ }^{33}$ If the borrower did contract with $C_{l}$ for such an arrangement, the contract would be disregarded when the borrower entered bankruptcy. ${ }^{34}$ Similarly, under U.S. law, the borrower may not give $C_{1}$ 's claim de facto priority over that of $C_{2}$ by making preferential payments to $C_{l}$ on the eve of bankruptcy. ${ }^{35}$

30. See THOMAS H. JACKSON, THE LOGIC AND Limits OF BANKRUPTCY LAW 4 (1986).

31. See generally INTERNATIONAL CORPORATE INSOLVENCY LAW, supra note 1 (describing allocation rules of various countries). Pro rata sharing is, of course, only one of many possible methods for allocating bankruptcy value. See, e.g., Schwartz, Theory, supra note 23, at 228-35 (suggesting that claims of initiai lenders should have priority in bankruptcy over claims of later creditors).

32. Thus, a borrower may not contract around the U.S. bankruptcy provisions. See Robert K. Rasmussen, Debtor's Choice: A Menu Approach to Corporate Bankruptcy, 71 TEX. L. REV. 51.61 (1992); Rogers. supra note 8, at 994-95.

33. See Rogers, supra note 8 , at $994-95$.

34. See id.

35. See 11 U.S.C. $\$ 547(b)$ (1994). 
In order for $C_{1}$ to effectively subordinate $C_{2}$ 's claim, $C_{1}$ must negotiate a subordination agreement with $C_{2}$ under which $C_{2}$ explicitly promises to pay $C_{l}$ as much of what $C_{2}$ receives in bankruptcy as is necessary to make $C_{l}$, whole. In fact, such subordination agreements are often negotiated between different creditors of the same borrower. Presumably, the subordinated creditors are compensated for such arrangements, by either the other creditors or the borrower (through a higher interest rate). However, the critical point is that the priority rankings of the subordinated creditors' claims are not lowered without their consent.

While the borrower may not give $C_{1}$ 's claim priority over $C_{2}$ 's with a simple contract, under the rule of full priority it may do so in effect merely by creating a security interest in favor of $C_{l}$. It is anomalous that, by complying with a few mechanical procedures, the borrower and $C_{l}$ may arrange to give $C_{1}$ 's claim priority not only over $C_{2}$ 's claim, but also over the claims of every other ordinary unsecured creditor without any of those creditors' consent, when the general rule is that the borrower may not give $C_{1}$ 's claim priority over that of any other unsecured creditor without the latter's consent.

To be sure, there would appear to be a clear difference between a simple contract between the borrower and $C_{l}$ providing priority for $C_{l}$ 's claim over that of $C_{2}$ and a security interest created by the borrower that leads to the same outcome. In order for the security interest to ensure that $C_{l}$ 's claim has full priority over $C_{2}$ 's, $C_{1}$ generally must perfect the security interest by recording it in a public registry. ${ }^{36}$ It therefore might be argued that a security interest and a simple contract giving $C_{1}$ 's claim priority over that of $C_{2}$ are not really alike: Since the security interest is publicly registered, creditors whose bankruptcy allocation is affected by the creation of the security interest may learn of the security interest and adjust the terms of their arrangements with the borrower to compensate themselves for the risk of subordination in bankruptcy. Consequently, the argument might go, while these creditors may not explicitly consent to subordination, they nevertheless give their implicit consent by taking the security interest into account when contracting with the borrower.

But to the extent that the other creditors of a borrower are unable to adjust the terms of their arrangements when the borrower creates a security interest subordinating their claims, the argument that these creditors implicitly consent to subordination loses its force. And, as we will show in Part IV, many of the creditors of a commercial borrower are likely to be nonadjusting with respect to security interests created by the borrower. These nonadjusting creditors will include tort creditors, whose claims are determined by judicial process without regard to the possibility that the claims may be subordinated in bankruptcy. A borrower's nonadjusting creditors will also include government tax and

36. See supra note 11 and accompanying text. 
regulatory agencies, the claims of which cannot be adjusted because they are fixed by statute. A borrower will also have many creditors whose claims are so small that it simply is not practical for these creditors to attempt to learn about the creation of a particular security interest and adjust their terms accordingly. Finally, any unsecured creditors that extend credit on fixed terms before a security interest is created simply do not have the opportunity to adjust these terms when the security interest is created. When these creditors are not able to adjust their claims against the borrower when it creates a security interest subordinating their claims, they cannot be regarded as even implicitly consenting to the subordination of their claims.

It should be clear that the rule of full priority creates a discontinuity between a borrower's general inability to subordinate the claim of one unsecured creditor to that of another and its ability, through the use of a security interest, to transform an unsecured creditor into a secured creditor with a claim that has priority over not one but all of the borrower's unsecured creditors. Full priority is consequently in tension-rather than in harmony-with an important principle of bankruptcy law-that a borrower may not circumvent the statutory allocation scheme by changing the priority rankings of various creditors without their consent.

\section{B. Value Transfer and Efficiency}

Having shown that according priority to secured claims in bankruptcy is in tension with an important principle of bankruptcy law, we now turn to the intuition that underlies much of our economic analysis: that, when two parties are able to create a contractual arrangement that transfers value from a nonconsenting third party, they will have an incentive to create such an arrangement even if value is lost as a result. That is, the two parties will have an incentive to transfer value from the nonconsenting party even if doing so reduces the total value that is available to all three parties.

As we have explained, the general approach of bankruptcy law is to prohibit a borrower from increasing the bankruptcy allocation of one creditor at the expense of another creditor through nonconsensual subordination of the other creditor's claim. To the extent that this approach is followed, the borrower is prevented from entering into value-reducing arrangements that merely transfer bankruptcy value from one creditor to another. From the standpoint of efficiency, the general prohibition against nonconsensual subordination is therefore desirable.

In contrast, full priority permits a borrower to subordinate the claims of nonconsenting unsecured creditors. This in turn gives the borrower and the secured creditor an incentive to use even value-reducing arrangements to transfer value from these parties. We will show that a borrower's ability to transfer value by using security interests may in fact cause the borrower to 
create a security interest in order to transfer bankruptcy value to the secured creditor, even if use of the security interest would be inefficient. We will further show that full priority may also distort the borrower's investment and precaution decisions and reduce the secured creditor's incentive to control inefficient behavior by the borrower after credit is extended. ${ }^{37}$

All of the above inefficiencies result from the ability of a borrower, under full priority, to transfer value from nonconsenting unsecured creditors. To the extent that a borrower is not permitted to transfer value from nonconsenting creditors, it will have less of an incentive to adopt value-reducing arrangements for that purpose, and the severity of the inefficiencies will decrease. For this reason, a rule according only partial priority to secured claims may well be more efficient than the rule of full priority.

\section{Would Adopting a Partial-Priority Rule Be a Radical Change?}

The rule of full priority is inconsistent with the general prohibition against the nonconsensual subordination of creditors' claims and thus at odds with a fundamental principle of bankruptcy law. Nevertheless, the principle of full priority has a long history in U.S. bankruptcy law, ${ }^{38}$ and the notion that a secured creditor is entitled to the full value of the collateral backing its interest is deeply rooted in thinking about the subject. Thus, even if a partial-priority rule appears to be desirable from the standpoint of efficiency, there might be reluctance to adopt such a rule. There might be a concern that such a dramatic change would disrupt credit markets. At the very least, the apparent radicalness of partial priority might suggest that its proponents should bear a heavy burden of persuasion.

But the adoption of a formal rule of partial priority would not in fact be as sweeping a change as it might seem. Notwithstanding the long history of the principle of full priority, certain features of Chapter 11 reorganizations tend either to waste value or to enrich junior claimants at the expense of secured creditors. ${ }^{39}$ Since $30 \%$ of business bankruptcy proceedings begin in Chapter $11,{ }^{40}$ secured creditors are often accorded less than full priority. ${ }^{41}$ Thus, the

37. See infra Part V.

38. See BAIRD \& JACKSON, supra note 3, at 470-73.

39. Full priority may be eroded, for example, when courts undervalue the claims of secured creditors or when the collateral backing these claims loses value during the course of the proceeding. The current erosion of the value of secured claims in bankruptcy is described in more detail infra Section VI.C.

40. 1995 BANKRUPTCY YEARBOOK \& AlMANAC 8 (Christopher M. McHugh ed., 5th ed. 1995).

41. See, e.g., Douglas G. Baird \& Thomas H. Jackson, Corporate Reorganizations and the Treatment of Diverse Ownership Interests: A Comment on Adequate Protection of Secured Creditors in Bankruptcy, 51 U. CHI. L. REv. 97, 127-29 (1984); Lawrence A. Weiss. The Bankruptcy Code and Violations of Absolute Priority. J. APPLIED CORP. FIN.. Summer 1991, at 71; White. Recent Erosion, supra note 23, at $402-04$. 
U.S. bankruptcy system already implements a rule of de facto partial priority. $^{42}$

Although our analysis does suggest that the existing erosion of full priority in the United States may lead to more efficient contracting between commercial borrowers and their creditors, the current regime achieves partial priority in an undesirable manner. ${ }^{43}$ For example, the current erosion of priority is ad hoc, creating unnecessary uncertainty for creditors. In contrast, the partial-priority rules we present are designed specifically to achieve the efficiency benefits of partial priority at the least possible cost. ${ }^{44}$

Although these partial-priority rules would operate differently from the existing erosion of priority, the fact that we are currently living under a partialpriority regime is useful for assessing whether an explicit partial-priority rule may be considered as a possible alternative to the rule of full priority. At the very least, the fact that the United States (and many other countries) in practice do not completely respect the principle of full priority should eliminate concerns that a partial-priority rule would necessarily disrupt commercial credit markets.

\section{THE PRIORITY-INDEPENDENT VALUE OF SECURITY INTERESTS}

We have seen that full priority is actually at odds with bankruptcy law's general prohibition against nonconsensual subordination, and that efficiency problems are likely to arise when-as occurs under full priority-value is transferred from nonconsenting third parties. We will now highlight a point that will play an important role in our analysis of the efficiency consequences of full priority: that many of the efficiency benefits and costs associated with security interests are not connected to the priority accorded secured claims over unsecured claims in bankruptcy.

As this part will explain, the use of a security interest confers a number of "priority independent" efficiency benefits, most of which arise from the security interest's ability to reduce inefficient behavior ("misbehavior") by the borrower. However, the use of the security interest also creates certain priority-

42. The United States is not the only country that fails to completely respect the principle of full priority in bankruptcy. Germany, for example, has recently adopted insolvency provisions modeled on Chapter 11 that will also have the effect of transferring value from secured creditors to unsecured creditors. See infra notes 168-70 and accompanying text. In a number of other European countries, the claims of certain preferred creditors have long been given priority over the claims of secured creditors. For example, in the United Kingdom and Ireland, certain unsecured creditors enjoy "superpriority" in the assets of a debtor that are subject to a floating charge. See EUROPEAN CORPORATE INSOLVENCY 331. 355 (Harry Rajak et al. eds., 1995) (Ireland); INTERNATIONAL CORPORATE INSOLVENCY, supra note 1, at 140 (United Kingdom). In Canada, claims for payroll withholding taxes have priority over the claims of secured creditors. See LoPucki. supra note 8, at 1922 n.133. And in France. employees' claims are given priority over those of secured creditors. See EUROPEAN CORPORATE INSOLVENCY, supra, at 160.

43. See infra Section VI.C.

44. See infra Sections VI.A-B. 
independent efficiency costs, which may exceed these benefits. The priorityindependent value of the security interest may be more or less than the efficiency value of a comparable set of covenants.

\section{A. The Problem of Borrower Misbehavior}

Most of the priority-independent efficiency benefits conferred by the use of a security interest arise from its ability to reduce misbehavior by the borrower. It is thus worth exploring why and how a firm may act inefficiently once it receives credit.

The objective of a firm's owners-maximization of the expected return from their investment in the firm ${ }^{45}$-does not take into account the effect of the firm's activities on its creditors. ${ }^{46}$ As a result, the firm's shareholders will be willing to pursue any activities that increase the expected value of their interests in the firm, even if those activities increase the expected loss facing the firm's creditors. The pursuit of such activities will be inefficient if total value decreases as a result-that is, if the expected value of creditors' claims decreases by more than the increase in the owners' expected returns.

Although it is by now well understood that the owners of a firm will often have an incentive to act inefficiently once the firm borrows money, ${ }^{47}$ some simple numerical examples will make this point more concrete. ${ }^{48}$ Suppose that a firm borrows $\$ 3$ million from its creditors that it promises to repay at the end of the year. ${ }^{49}$ Once the credit has been extended, the firm's owners are faced with a choice between two projects, one of which is "safe" and the other of which is "risky." The safe project will yield $\$ 3.9$ million by the end of the year with certainty. The risky project will yield $\$ 4$ million at the end of the year with $95 \%$ probability and $\$ 1$ million with $5 \%$ probability. Since the expected value of the risky project is only $\$ 3.85$ million, ${ }^{50}$ from the standpoint of efficiency, it would be desirable for the owners of the firm to pursue the safe project, which has a value of $\$ 3.9$ million.

Now consider the incentives facing the firm's owners. At the end of the year, creditors' claims must be paid before the owners are entitled to whatever

45. Although it is not necessary for our analysis, we assume for the sake of simplicity that those controlling the firm always seek to maximize equity value.

46. Shareholders are generally indifferent to the effect of their firm's activities on its creditors because, under the rule of limited liability, they personally need not make the firm's creditors whole if the firm is unable to pay its debts.

47. See William A. Klein \& John C. Coffee, JR., Business Organization and Finance 255-58, 355-57 (5th ed. 1993); Clifford W. Smith, Jr. \& Jerold B. Warner, On Financial Contracting: An Analysis of Bond Covenants. 7 J. FiN. ECoN. 117, 118-19 (1979). III.B.

48. Readers familiar with the concept of borrower misbehavior may wish to proceed directly to Section

49. For simplicity, it is assumed in all of the examples in this Article that any interest charged by creditors is paid in one lump sum by shareholders when credit is extended.

50. The expected value of the project is simply the payoff under each contingency multiplied by the probability of that contingency's occurring: $(0.95 \times \$ 4$ million $)+(0.05 \times \$ 1$ million $)=\$ 3.85$ million. 
remains-the firm's residual value. If the owners pursue the safe project, the residual value available to them at the end of the year will be $\$ 900,000$ ( $\$ 3.9$ million less $\$ 3$ million in principal owed creditors). Thus, the value to the owners of pursuing the safe project would be $\$ 900,000$. On the other hand, the residual value from the risky project would be $\$ 1$ million if the project succeeds, and $\$ 0$ if the project fails, providing the owners with an expected return of $\$ 950,000$. The owners will therefore choose the risky project because its expected value to them is greater. By choosing the risky project over the safe project, the owners reduce the expected value of the creditors' claims by $\$ 100 ; 000^{51}$ while increasing the expected value of their equity interests by only $\$ 50,000$. Thus, from the perspective of efficiency, the owners' choice of the risky project is not desirable.

In general, a firm's owners will tend to prefer higher-risk, higher-return projects since they will capture all of the additional return if the projects succeed. In contrast, creditors as a group will generally be made worse off by higher-risk, higher-return projects because such projects increase the likelihood that the firm will fail and their claims will not be paid fully. ${ }^{52}$ This type of misbehavior — choosing a risky project that makes creditors worse off by more than it makes shareholders better off-is referred to as "overinvestment."

The shareholders of a firm may also engage in another form of misbehavior- "asset dilution"- - which consists of taking assets out of the firm, where they will be out of reach of creditors if the firm fails. ${ }^{54}$ Although both corporate and commercial law place some limits on the ability of a firm to distribute value to its shareholders when the firm is insolvent, ${ }^{55}$ those controlling the firm nevertheless retain substantial discretion in deciding whether to transfer corporate assets to shareholders. Since a firm's creditors are generally made worse off when assets are removed from the firm, ${ }^{56}$ asset dilution may be inefficient.

Continuing with the previous example, suppose that the firm's owners have chosen to pursue the risky project, which, although less efficient than the safe project, is expected to make them better off. Recall that there is a $95 \%$ chance that the project will yield $\$ 4$ million at the end of the year and a $5 \%$ chance that it will yield $\$ 1$ million. Now assume that, at some point before the project

51. There is a 5\% chance that the creditors collectively will lose $\$ 2$ million if the owners pursue the risky project.

52. See Triantis, Secured Debt, supra note 23, at 237-38.

53. See Smith \& Warner, supra note 47 , at $118-19$.

54. See id. at 118 .

55. See generally ROBERT C. CLARK, CORPORATE LAW 593-638 (1986) (discussing limits on firm's ability to distribute value of firm upon insolvency); Morey W. McDaniel, Bondholders and Corporate Governance, 41 BuS. LAW. 413, 432 (1986).

56. See Triantis. Secured Debt, supra note 23. at 235. The removal of assets from a firm would make creditors worse off by reducing the incentive and ability of the firm's owners to run the firm well. thereby increasing the likelihood of failure. Asset dilution would also hurt creditors by reducing the amount of assets that would be available to satisfy creditors' claims in the event the firm fails. 
is completed, the owners are given the opportunity to sell $\$ 96,000$ of the firm's assets and distribute the proceeds to themselves. Assume further that the firm must temporarily cease operating in order for the assets to be sold and removed, causing the firm to lose $\$ 4000$ in profits. As a result, the effect of the sale and distribution would be to reduce the firm's assets at the end of the year by $\$ 100,000$, whether the risky project succeeds or fails. Thus, if the assets are removed, the project will yield $\$ 3.9$ million if it succeeds (rather than $\$ 4$ million) and $\$ 900,000$ if it fails (instead of $\$ 1$ million).

Since the sale and removal of the assets would reduce the value of the firm by $\$ 100,000$, and the firm's shareholders would receive only $\$ 96,000$ in cash, the asset dilution would be inefficient. However, again consider the incentives facing the owners. If the owners remove the assets, they end up with $\$ 96,000$ in cash and equity claims worth $\$ 855,000^{57}$ (for a total value of $\$ 951,000$ ). If, on the other hand, they leave the assets in the firm, they would have equity claims worth only $\$ 950,000$. The owners will thus have an incentive to engage in inefficient asset dilution. This incentive arises because the owners, on an expected-value basis, do not bear the full cost $(\$ 100,000)$ of removing the $\$ 96,000$ from the firm. Since there is a $5 \%$ chance that the firm will fail, and all of the remaining assets will be distributed to the creditors, creditors bear an expected cost of $\$ 5000 .^{58}$ Thus, the expected cost to the shareholders of removing the $\$ 96,000$ is only $\$ 95,000$, making the inefficient asset dilution worthwhile to them.

\section{B. The Priority-Independent Benefits of Security Interests}

The use of a security interest confers a number of priority-independent efficiency benefits, mostly by reducing the ability of the borrower to engage in the types of inefficient behavior described in Section A. These priorityindependent efficiency benefits arise from the special rights accorded to secured creditors outside of bankruptcy: the "repossessory right" and the statelaw "priority right."

As we have explained, the "repossessory right" may permit a secured creditor to seize the collateral from a borrower more quickly than it could as an unsecured creditor. ${ }^{59}$ The state-law "priority right" gives the creditor priority in the collateral that usually remains attached even if the collateral is

57. The owners will have a $95 \%$ chance of receiving $\$ 900,000$. The expected value of their claim is thus $(0.95 \times \$ 900.000)$ or $\$ 855.000$.

58. There is a 5\% chance that creditors will bear the full $\$ 100,000$ cost of removing the $\$ 96.000$ from the firm.

59. However, an important limit on the secured creditor's ability to seize the collateral is that it cannot breach the peace to do so. See U.C.C. \$ 9-503 (1994). 
sold, transferred, or encumbered by third parties. ${ }^{60}$ Since the secured creditor continues to have a right to seize the collateral in satisfaction of the original borrower's debt even if the collateral has left the borrower's possession, the state-law "priority right" renders the encumbered collateral virtually worthless to other parties.

The state-law "priority right" and the "repossessory right" thus give security interests the ability to:

(1) reduce overinvestment by preventing a borrower from selling or encumbering the collateral to raise funds for an inefficient project; ${ }^{61}$

(2) reduce inefficient asset dilution by preventing a borrower from transferring the collateral to its shareholders, or selling or encumbering the collateral to raise funds to transfer to its shareholders; ${ }^{62}$

(3) reduce the costs associated with default by allowing the secured creditor to avoid judicial process in certain situations; ${ }^{63}$

(4) reduce indirectly inefficient behavior by increasing the expected cost to a borrower of violating covenants in the loan contract with a secured creditor; ${ }^{64}$ and

(5) reduce the incentive of creditors to rush for assets when a borrower begins suffering financial difficulties. ${ }^{65}$

60. See, e.g., id. \$ 9-312. However, if the borrower sells the collateral in the ordinary course of his business to a good-faith purchaser, the security interest will not remain attached when the property is transferred to the purchaser. See id. \$9-307.

61. See Smith \& Warner, supra note 47 , at 127; Stulz \& Johnson, supra note 23 , at 513: Triantis, Secured Debt, supra note 23, at 247.

62. See Carlson. supra note 23, at 2191; Stulz \& Johnson, supra note 23. at 513; Triantis. Secured Debt, supra note 23, at 247.

63. See Kripke, supra note 23, at 948; Leeth \& Scott, supra note 4, at 381-82; Schwartz, Security Interests, supra note 23 , at 29 n. 50 .

64. The "repossessory right" reduces the cost to a secured creditor of declaring default, thereby increasing the likelihood that the secured creditor will seek to recover the unpaid balance on the loan from a borrower if it discovers a violation of a covenant. The "repossessory right" also allows the secured creditor to seize the collateral and (if the borrower is too cash constrained to bid for the collateral) sell it at a price below its value to the borrower. The increased likelihood that the secured creditor will call a default and the possibility that the collateral will be seized and sold below its value to the borrower together raise the expected cost to the borrower of defaulting on the covenants, thereby making compliance more likely. See Carlson, supra note 23, at 2190; Triantis, Secured Debt. supra note 23, at 246; see also Scott, supra note 6, at 920-21 (arguing that security interest may give financing creditors leverage to deter borrower from inefficient underinvestment). Some commentators have also suggested that since it may be more costly for a borrower to default on a secured loan than on an unsecured loan, a borrower may be able to "signal" its belief that it is unlikely to experience difficulties repaying the loan-and thereby procure credit at a lower cost-by offering a security interest to a potential lender. See. e.g.. Triantis. Theoretical Observations, supra note 23 , at 41-52.

65. A security interest in a borrower's assets giving the secured creditor a "priority right" outside of bankruptcy makes it futile for unsecured creditors to rush for the borrower's assets at the first sign of impending failure. See Picker, supra note 4, at 657. 


\section{The Priority-Independent Costs of Security Interests}

While the use of a security interest may offer some or all of the priorityindependent efficiency benefits just cited, its use also entails three types of priority-independent efficiency costs. These costs are: (1) "contracting costs"-including the cost of negotiating and perfecting the security interest; (2) "enforcement costs" - the costs of policing the collateral; and, perhaps most importantly, (3) "opportunity costs"-the costs created when the security interest prevents the borrower from pursuing efficient activities.

The cost of drafting a security agreement that gives the secured creditor a "repossessory right" in the collateral is trivial, but complying with the procedural requirements necessary for the creditor to establish a "priority right" can be quite expensive, at least with respect to personal property. ${ }^{66}$ To ensure that the security interest is effective against third parties outside of bankruptcy, a secured creditor is required to ascertain that the collateral is not encumbered by any prior liens that would take priority, ${ }^{67}$ and then to "perfect" its interest-usually either by taking possession of the collateral or by filing a financing statement in a public registry or registries-so that the right will be effective against future claimants. ${ }^{68}$ The design of the public registry system in the United States makes both of these procedures cumbersome and therefore expensive, particularly in the case of multijurisdictional transactions. ${ }^{69}$ Indeed, anecdotal evidence suggests that contracting costs in the United States can be relatively high. ${ }^{70}$

66. Acquiring priority in real property is generally cheaper, although state recordation taxes can make recording a mortgage quite expensive in certain jurisdictions. See generally Johnson, supra note 23 , at $340-47$ (discussing advantages of real property as security).

67. Prior perfected security interests in personal property will generally have priority over later perfected security interests. See U.C.C. \$ 9-312(5) (1994).

68. See id. \$ 9-302.

69. Under the U.S. system, a prior valid lien may be filed in a state other than the one in which the collateral is currently located. See id. $\$ 9-103$. A prior valid lien may also be filed under a name other than the one currently used by the debtor. See id. $\$ 9-402(7)$ (prior secured creditor's financing statement remains effective for four months after debtor's name has changed). For a description of these and other types of filings that are essentially undiscoverable under the present filing system, see Lynn M. LoPucki, Computerization of the Article 9 Filing System: Thoughts on Building the Electronic Highway. LAW \& CONTEMP. ProBS., Summer 1992, at 5, 7; Gerald T. McLaughlin. "Seek But You May Not Find": NonUCC Recorded, Unrecorded and Hidden Security Interests Under Article 9 of the Uniform Commercial Code, 53 FordhaM L. REv. 953, 972-93 (1985). New liens must frequently be registered in a number of different offices (so as to ensure priority in the assets as they move from jurisdiction to jurisdiction), which involves significant expense. See LoPucki, supra, at 16 n.64.

70. See, e.g., MANN, supra note 4, at $47-48$ (reporting that transaction costs in connection with obtaining $\$ 10$ million secured loan are $\$ 75,000-\$ 125,000$ higher than transaction costs for same size unsecured loan): Peter A. Alces, Abolish the Article 9 Filing System, 79 MINN. L. REv. 679. 690-91 (1995) (reporting study finding that average filing cost of secured transaction handled by large Boston law firm was $5.52 \%$ of total legal fee, or more than $\$ 25,000$ per transaction); Fred R. Bleakley, Continuing Crunch: Many Midsized Firns Still Find That Insurers and Banks Deny Loans. WALL ST. J.. Nov. 16. 1992. at Al, A6 (reporting that one borrower recently had to pay " 10 times as much in lawyers' fees" as when it previously borrowed from same lender to put specific collateral into new loan agreement). 
After the security interest is created and perfected, a secured creditor must maintain the effectiveness of its interest. To ensure that the secured creditor's "repossessory right" and state-law "priority right" remain effective, the secured creditor must incur enforcement costs by "policing" the collateral to ensure that the collateral retains as much value as possible; that the collateral is not dissipated, transferred to an unknown party, or destroyed; and that the secured creditor's claim is not subordinated to that of a future claimant. ${ }^{71}$ The cost of policing the collateral will vary from case to case and depend largely on the nature of the assets involved.

Finally, although a security interest may be able to reduce a borrower's ability to engage in overinvestment, or inefficient asset dilution that would require disposing of or encumbering the collateral, the security interest may also prevent the borrower from undertaking certain projects or distributing assets to its shareholders when those activities would be efficient. ${ }^{72}$ The inability of the borrower to pursue efficient activities gives rise to the third (and most important) efficiency cost of a security interest-opportunity cost.

The magnitude of each of these costs will of course vary from case to case. The important point for our analysis is that there are priority-independent efficiency costs to using a security interest, and that these costs may be greater than the priority-independent efficiency benefits of the security interest.

\section{The Relative Value of Covenants}

A set of covenants ${ }^{73}$ may closely replicate the effects of, and therefore be a substitute for, a security interest. ${ }^{74}$ Thus, even when the priorityindependent benefits of a security interest exceed its priority-independent costs, the priority-independent value of that security interest may still be less than the efficiency value of a set of covenants.

71. The secured creditor may lose priority in personal-property collateral, if, for example, the filing lapses, see U.C.C. $\$ 9-403$ (2) (1994), the debtor creates another security interest in the property under a new name and the original secured creditor has not filed a new financing statement within the four-month grace period, see id. $\$ 9-402(7)$, the collateral is moved to another state and becomes subject to a new security interest, see id. $\$ 9-103$, or a bona fide purchaser of the collateral takes it free and clear of the security interest under state law, see id. \$ 9-307.

72. See, e.g., Buckley, supra note 23, at 1437-39; Carlson, supra note 23, at 2190-91; Triantis, Secured Debt, supra note 23, at 247-48.

73. We use the term "covenant" in this Article to describe an obligation by a borrower to a creditor that is not connected to a security interest. For example, a restriction on dividend payments would be considered a covenant, but a contractual term in a loan agreement requiring that the borrower insure, maintain, and allow the inspection of collateral subject to the creditor's security interest would be considered an element of the security interest (and not a covenant). A covenant may be either negative, such as a prohibition against undertaking specified investments or issuing dividends to shareholders, or positive, such as a requirement that the borrower maintain a certain net worth. See Smith \& Warner, supra note 23 , at $247-49$.

74. See Triantis, Secured Debt, supra note 23, at 257. For anecdotal evidence that lenders view covenants and security interests as substitutes, see MANN, supra note 4, at 36 n.100. 
A security interest can at most prevent a borrower from acting inefficiently in ways that would require the sale, transfer, or pledging of the collateral. A security interest cannot prevent a borrower from using the collateral to engage in overinvestment, or from using other assets for that purpose. ${ }^{75}$ Nor can a security interest prevent a borrower from inefficiently transferring other assets to its shareholders.

In contrast, covenants can be used to control a broader range of inefficient behavior. Covenants may be able to achieve the same effects as a security interest by requiring that the borrower not encumber or transfer certain assets. In addition, covenants can be used to restrict, directly or indirectly, the borrower's investment activities, to bar the creation of certain security interests, to limit dividend and other payments to shareholders, or even to require the borrower to remain in the same line of business. ${ }^{76}$ Since individual covenants can be tailored as narrowly or as broadly as is deemed appropriate, a set of covenants may be more effective than a security interest in preventing borrower misbehavior while generating smaller opportunity costs.

To be sure, a creditor and a borrower cannot anticipate all contingencies when drafting covenants. Thus, covenants may fail to prevent certain inefficient behavior. In addition, there are costs inherent in the use of any set of covenants, and these costs may be substantial. The cost of drafting covenants may be high if standard loan agreements are not used. Enforcement costs may tend to be higher than when security interests are used, especially when the borrower can easily conceal violations of the covenants. ${ }^{77}$ Finally, since it is impossible to specify all possible contingencies in the covenants, covenants might be overinclusive in some respects and generate opportunity costs. ${ }^{78}$ However, the critical point is that, even when the priority-independent benefits of a security interest are greater than its priority-independent costs, the priority-independent value of the security interest may be less than the efficiency value of an appropriate set of covenants.

Having seen that a security interest may have priority-independent efficiency benefits that are less than its priority-independent efficiency costs, we will next examine why commercial borrowers and their creditors have an incentive to use inefficient security interests in their arrangements when full priority is accorded to secured claims.

75. See Buckley, sitpra note 23 , at 1438.

76. See generally Smith \& Warner, supra note 47 (describing various limitations that may be placed on borrowers through use of bond covenants).

77. See infra note 115 and accompanying text.

78. See Triantis, Secured Debt, supra note 23, at 240. 


\section{THE INCENTIVE TO USE SECURITY INTERESTS UNDER FULL PRIORITY}

The purpose of this part is to show that, in the presence of nonadjusting creditors, the parties to a loan contract may have an incentive to use an inefficient security interest when secured claims are accorded full priority in bankruptcy. Section IV.A begins by introducing a hypothetical borrower ("Firm") and a hypothetical creditor ("Bank"). Section IV.B shows that in an ideal world of perfectly adjusting creditors, there is no divergence between the privately and socially desirable arrangements of Bank and Firm under full priority because Bank and Firm have an incentive to use a security interest if and only if it is socially optimal to do so. As Section IV.C explains, however, the real world contains many creditors that are not perfectly adjusting. Section IV.D demonstrates that, in the presence of nonadjusting creditors, the privately and socially optimal arrangements of Bank and Firm will tend to diverge, since Bank and Firm will have an incentive to use inefficient security interests in order to transfer value from these creditors.

\section{A. The Loan Contract Between Firm and Creditor}

The analysis that follows will focus on a hypothetical relationship between Bank, a creditor that is in the business of lending money to commercial borrowers, and Firm, a commercial borrower. ${ }^{79}$ We assume that the size of the loan that Bank is considering extending to Firm is sufficiently large that the parties will find it worthwhile to negotiate over including a security interest and/or covenants in the loan agreement. As is standard in any loan contract, Firm will promise payments of interest to Bank that will reflect Bank's risk of loss and the various costs it expects to incur in connection with the loan, s0 which in turn will depend on the extent to which the parties incorporate a security interest and covenants into the loan agreement. ${ }^{81}$ The arrangement negotiated between Bank and Firm will also implicitly incorporate all of the mandatory rules that govern the relationship between commercial borrowers and their creditors, including the rules determining the treatment of secured claims in bankruptcy. ${ }^{82}$

79. Although our analysis focuses on the case of a hypothetical corporate borrower, it is applicable to any entity that is engaged in commercial activity, such as a partnership, trust, or proprietorship.

80. Fischer Black, Bank Funds Management in an Efficient Market, 2 J. FIN. ECoN. 323, 328 (1975).

81. We assume that Bank does not seek to protect itself further through arrangements with parties other than Firm, such as by requiring guarantees from Firm's shareholders. However, it would not affect our conclusions if Firm's shareholders and Bank negotiated such an arrangement.

82. In Part $\mathrm{V}$, we assume that the option to create a security interest giving Bank full priority in specified assets of Firm. while potentially beneficial to Bank and Firm, is not critical to the transaction. That is, we assume that Bank will extend credit to Firm even if its secured claim does not receive full priority in bankruptcy, although in such a case the interest rate may be higher and more covenants may be adopted. In Part VII, we relax the assumption that the transaction will take place regardless of the priority 
From the standpoint of efficiency, the arrangement will be desirable to the extent that it increases social wealth. Therefore, the optimal arrangement is the one that maximizes the value captured by Firm, Bank, and all other parties affected by the arrangement, which we assume to be Firm's other creditors. ${ }^{83}$ However, Bank and Firm will have an incentive to shape the arrangement-which may or may not include a security interest-in the manner that maximizes their private joint gains. As we will see, in the presence of nonadjusting creditors, the arrangement that makes them best off is unlikely to be the socially optimal arrangement. Our aim will be to analyze systematically the ways in which the rule of full priority for secured claims increases the divergence between the socially desirable arrangement and the one Bank and Firm have an incentive to adopt.

\section{B. The Easy Case for Full Priority in a World with Perfectly Adjusting Creditors}

To isolate the factors that make the rule of full priority for secured claims problematic from the perspective of efficiency, it is worth starting with an analytical exercise: stipulating the assumptions under which according full priority to secured claims would lead borrowers to issue security interests if and only if it were socially optimal to do so. As will be shown, the inefficiencies associated with according full priority to secured claims result from the fact that these assumptions do not obtain in our world.

Consider a world in which the claims of all creditors other than Bank perfectly reflect all elements of the agreement between Bank and Firm. Imagine, for example, that all of the other claims arise subsequent to the transaction between Bank and Firm. Suppose further that all of the other creditors are contractual creditors that are perfectly informed about all aspects of the contract between Bank and Firm and are able to take this information into account in shaping their contracts with Firm.

In such a world, the arrangement between Bank and Firm could not impose a negative externality on these other creditors, meaning that Bank and Firm could not make these creditors worse off. Thus, Bank and Firm would never adopt an inefficient security interest in order to divert value from other creditors. These creditors would simply respond by raising their interest rates to recover the value diverted, leaving Bank and Firm to bear the net efficiency costs associated with the inefficient security interest. Nor in such a world could the arrangement between Bank and Firm confer a positive externality on the other creditors, making them better off, since the other creditors would reduce

rule and extend the analysis to the case in which certain loan transactions-and the activities they are intended to finance-will not take place without full priority.

83. See supra note 26. 
the size of their claims against Firm to reflect the benefits flowing to them from the arrangement. Thus, Bank and Firm would capture all of the benefits of any contractual term that is desirable, and have an incentive to adopt it.

Since Bank and Firm would bear all of the net efficiency losses and enjoy all of the net efficiency benefits of their arrangement, Bank and Firm would find it in their interest to choose the socially optimal arrangement. The bargain struck between Bank and Firm would therefore tend to be efficient. Thus, according full priority to secured claims in bankruptcy could not give rise to any inefficiencies.

\section{The Presence of Nonadjusting Creditors}

In the real world, in contrast to the world assumed in the previous section, the use of a security interest giving Bank's secured claim full priority may make Bank and Firm better off by transferring bankruptcy value from creditors that cannot adjust the size of their claims against Firm to take into account the existence of the security interest. And, as we will see, every commercial borrower will have many creditors that are unable to make such adjustments.

\section{Private Involuntary Creditors}

It is by now a familiar point in the law review and finance literature that according full priority to secured claims permits a firm to divert value from its tort creditors. ${ }^{84}$ Thus, it is natural to begin our discussion of nonadjusting creditors by considering the case of tort creditors that have unsecured claims against a bankrupt firm. Such claims arise when private parties are injured by the firm, and their claims exceed the firm's insurance coverage limits at the time the firm goes bankrupt.

Insurance companies typically impose limits on the scope and amount of coverage under their policies. ${ }^{85}$ In addition, shareholders have an incentive to underinsure because they do not reap all of the benefits of the insurance they purchase. ${ }^{86}$ As a result, firms generally choose insurance coverage limits that are not fully adequate. ${ }^{87}$ Thus, while a typical firm purchases insurance, ${ }^{88}$ such insurance may not cover all tort claims. If private tort claims do arise,

84. See, e.g., LoPucki, supra note 8, at 1898-99; James H. Scott, Jr., Bankruptcy, Secured Debt, and Optimal Capital Structure, 32 J. Fin. 1, 2-3 (1977); Shupack, supra note 23, at 1094-95.

85. See Henry Hansmann \& Reinier Kraakman. Toward Unlimited Shareholder Liability for Corporate Torts, 100 YALE L.J. 1879, 1889 (1991); LoPucki, supra note 8, at 1906-07.

86. See Hansmann \& Kraakman, supra note 85 , at 1889 (noting that shareholders do not face all costs of tort claims due to limited liability and therefore do not obtain all benefits of reducing these costs through insurance).

87. See id. at 1890.

88. See generally David Mayers \& Clifford W. Smith. Jr., On the Corporate Demand for Insurance, $55 \mathrm{~J}$. BuS. 281 (1982) (analyzing incentives for firms to buy property insurance and liability insurance in United States). 
there is the possibility that these tort creditors will have unsecured claims against the firm when it fails. And, while uninsured tort claims do not surface often in bankruptcy, when they do turn up, they can be substantial. ${ }^{89}$

These tort creditors cannot adjust their claims to reflect the existence of a security interest. Even if the amount of the claim is fixed after the firm creates a security interest, so that in principle the security interest could be taken into account in setting that amount, the size of the claim will be determined by a court without regard to the firm's financial structure. Thus, a firm may make tort creditors worse off by subordinating their claims to that of a secured creditor. ${ }^{90}$

Indeed, the problem of tort creditors in bankruptcy has been attracting considerable attention in the law review literature. ${ }^{91}$ Some commentators have urged that tort creditors be fully compensated when the corporate tortfeasor goes bankrupt, either through a program of mandatory insurance or by making shareholders liable for corporate torts. ${ }^{92}$ Others have suggested that tort creditors be given priority over secured claims ("superpriority") in bankruptcy. ${ }^{93}$

To the extent that any of these reform proposals are adopted, security interests could not be used to subordinate the value of tort claims, and the problem of tort creditor nonadjustment would be eliminated. But as long as tort creditors are not fully paid or given superpriority over secured claims when a tortfeasor firm goes bankrupt, tort creditors will continue to be nonadjusting with respect to the creation of security interests. ${ }^{94}$

89. See Samuel L. Bufford, What Is Right About Bankruptcy Law and Wrong About Its Critics, 72 WASH. U. L.Q. 829, 840 (1994). In two of 43 large bankruptcy reorganizations studied by LoPucki and Whitford, tort claims-for personal injury in one case, and for patent infringement in the other-amounted to more than two-thirds of the unsecured claims against the bankrupt company. See Lynn M. LoPucki \& William C. Whitford, Corporate Governance in the Bankruptcy Reorganization of Large, Publicly Held Companies, 141 U. PA. L. REv. 669, $738 \mathrm{nn} .226-27$ (1993); see also LoPucki, supra note 8, at $1906 \mathrm{n} .81$ (describing other cases in which tort liabilities of bankrupt firms were significantly in excess of applicable insurance coverage).

90. See Hansmann \& Kraakman, supra note 85, at 1884; LoPucki, supra note 8, at 1898; Shupack, supra note 23, at 1094-95. We assume that the injuries sustained by tort creditors, neither arise out of a contractual relationship with the borrower nor are sustained by voluntary nonadjusting creditors. To the extent that the tort creditors happen to be adjusting creditors, they can in principle adjust the terms of their arrangement with the borrower to reflect the possibility that any tort claims arising out of the relationship will be subordinated to secured claims.

91. See, e.g., Hansmann \& Kraakman, supra note 85; David W. Leebron, Limited Liability, Tort Victims, and Creditors, 91 ColUM. L. REv. 1565 (1991); Christopher M.E. Painter, Note, Tort Creditor Priority in the Secured Creditor System: Asbestos Time, the Worst of Times, 36 STAN. L. REV. 1045 (1984).

92. See, e.g., Hansmann \& Kraakman, supra note 85 (proposing unlimited shareholder liability for corporate torts); Steven Shavell, The Judgment Proof Problem, 6 INT'L REV. L. \& ECON. 45, 54 (1986) (proposing mandatory insurance).

93. See, e.g., Barry E. Adler, A World Without Debt, 72 WASH. U. L.Q. 811,826 (1994); Kathryn R. Heidt, Cleaning Up Your Act: Efficiency Considerations in the Battle for the Debtor's Assets in Toxic Waste Bankruptcies, 40 RUTGERS L. REV. 819, $851-63$ (1988); Leebron, supra note 91, at 1643-49; LoPucki, supra note 8, at 1913: Painter, supra note 91. at 1080-85.

94. It should be noted, however. that the problem of nonadjustment would not be eliminated under a mandatory insurance system that permitted the insurer to reach the bankruptcy assets of the tortfeasor firm as an unsecured creditor in order to recover payments made to the firm's tort victims. In such a case, 


\section{Government Tax and Regulatory Claims}

Although tort claims against bankrupt firms may in some cases be substantial, on aggregate they are not as significant as the claims of the second group of involuntary creditors: federal, state, and local government agencies with tax and regulatory claims. ${ }^{95}$

Firms are required to make periodic payments to federal, state, and local governments for corporate income taxes, withholding taxes on employees' salaries, social security contributions, sales tax, property tax, excise tax, and customs duties. When firms file for bankruptcy, at least some of these taxing authorities will be creditors for taxes due but not paid. ${ }^{96}$ In fact, tax claims against bankrupt firms are usually substantial, especially in the case of closely held firms. ${ }^{97}$

In addition, the government may have environmental, pension-related, and other nontax claims against a bankrupt firm. For example, a firm reorganizing under Chapter 11 may terminate an underfunded pension plan and have the government pick up the tab, giving rise to a government claim against the firm. ${ }^{98}$ Although these claims (unlike tax claims) will not be present in every bankruptcy, they may be substantial when they do arise. ${ }^{99}$

The size of the government's various tax and regulatory claims are set by statute without regard to a firm's capital structure and, in particular, without regard to any security interests the firm may have created that subordinate these claims to those of secured creditors. Thus, the government is nonadjusting with respect to any security interests created by a firm. As a result, when a firm and creditor must decide whether to create a security interest, the firm will treat its tax and regulatory obligations to the government-like its obligations to tort creditors-as fixed.

mandatory insurance would simply substitute one set of nonadjusting creditors (insurers) for another (tort creditors).

95. The government may also have claims against a firm arising out of loans guaranteed by the U.S. Small Business Administration or a similar state or federal agency. Such claims, which arise out of voluntary transactions and in principle are therefore adjustable, are not included in the category of "government tax and regulatory claims." It might be suggested that all claims of the federal government arise "voluntarily" because the federal government has the power to change the bankruptcy rules to favor itself (or to choose not to assert any claims against firms in the first instance). For our purposes, however, it is irrelevant whether the federal government is considered a voluntary or involuntary creditor with respect to its tax and regulatory claims.

96. See 11 U.S.C. \$ 507(a)(8) (1994).

97. See Baird, sipra note 17 , at 915 . In fact, it is believed that a substantial number of bankruptcy petitions are filed as result of tax debt. See Bufford. supra note 39 . at 840 .

98. See White, supra note 18, at E7-24.

99. See LoPucki, supra note 8, at 1897. 


\section{Voluntary Creditors with Small Claims}

We have just seen that involuntary creditors are not able to adjust the size of their claims when a borrower creates a security interest in favor of another creditor because their claims are fixed by law. But the fact that a creditor voluntarily contracts with a firm does not necessarily make that creditor adjusting with respect to any security interest created by the firm. Many of a firm's voluntary creditors are customers, ${ }^{100}$ employees, ${ }^{10 r}$ and trade creditors that have relatively small claims against the firm. Even though these creditors may sometimes, in principle, be able to take the existence of a security interest into account in contracting with the firm, the small size of their claims will generally make it irrational for them to do so.

The cost to any creditor of adjusting its terms with a firm to reflect accurately its risk of loss in connection with lending to that particular firm is likely to be substantial. Merely determining the extent of a firm's secured debt is quite difficult. ${ }^{102}$ And even if a creditor with a small claim could costlessly acquire information about a firm's secured debt, the creditor would still be required to estimate the firm's likelihood of insolvency, its insolvency value, and the extent of its unsecured debt, in order to estimate its own risk of loss. ${ }^{103}$ Finally, a creditor that had undertaken such an investigation would face the additional cost of negotiating with the firm for specialized terms.

While at any given time the amount of credit these parties extend collectively to a firm may be quite large, the amount that the firm owes to each of these creditors individually - and thus the expected loss faced by each creditor-is typically very small. As a result, the benefit to these creditors of acquiring information and negotiating special terms with the firm each time they extend credit would be negligible. Even trade suppliers, which are more commercially sophisticated than employees and customers, are believed to have neither the time nor the expertise to evaluate precisely individual firm risk. ${ }^{104}$ Although trade creditors may deny or limit credit to customers they perceive to be especially risky, they tend to charge uniform interest rates to all of their

100. Customers may be owed money for payments made toward purchases of goods or services. For example, ticket holders had substantial unsecured claims against Braniff Airlines when it went bankrupt. See id. at 1897 n.41.

101. See 11 U.S.C. \$ 507(a)(3)-(4) (1994).

102. One reason for this is that although public registries identify the types of assets subject to a security interest, they do not indicate the size of the loan secured by the collateral. See generally Douglas G. Baird, Notice Filing and the Problem of Ostensible Ownership, 12 J. LEGAL STUD. 53 (1983) (arguing that notice-filing system of Article 9 provides insufficient information to be of substantial assistance to unsecured creditors).

103. While reporting services. such as Dun \& Bradstreet, do compile financial information about firms. the information provided is of limited value. The services do not report on all firms. the UCC filing information on which they rely is itself not complete, see supra note 102 , and they lack details on the unsecured liabilities of most firms. As a result, these services are also believed by lenders to be untimely and inaccurate. See MANN, supra note 4, at 20-21.

104. See Hudson, supra note 27, at 56; Roe, supra note 27, at 225. 
customers that purchase on credit, ${ }^{105}$ indicating that when they extend credit to a customer they do not set the interest rate to take into account the risk of loss associated with lending to that particular customer. ${ }^{106}$

It is important to emphasize that the failure of creditors with small claims to investigate and take into account a borrower's arrangements with other creditors does not imply that they will always be undercompensated for bearing the risk of subordination in bankruptcy. It is quite possible that trade creditors set terms that compensate them for the average risk of loss they face in lending to all of their customers. However, whether or not these creditors are adequately compensated for their risk of loss is not relevant for our analysis. Our analysis assumes only that voluntary creditors with small claims do not adjust their terms to reflect whether or not a particular security interest has been created, and that a commercial borrower thus does not expect to pay a higher rate of interest to these creditors when it creates a security interest under the rule of full priority.

The following numerical example shows how creditors with small claims might be compensated fully for their risk of loss even though they are nonadjusting. Suppose that our hypothetical Firm-like other businesses in Firm's industry-has a 5\% chance of failing by the end of the loan period. Suppose further that trade suppliers typically lend $\$ 100,000$ to customers such as Firm. Finally, suppose trade creditors know that $80 \%$ of the firms in the industry encumber all of their assets, and trade creditors receive nothing in bankruptcy when these firms fail; and that $20 \%$ of the firms do not encumber all of their assets, and that on average trade suppliers recover $5 \phi$ on the dollar when these firms fail. ${ }^{107}$ The risk of loss associated with extending $\$ 100,000$ of credit to a fully encumbered firm would thus be $\$ 5000$ (the probability that the firm would fail multiplied by the amount that will be lost in the event of failure, i.e., $.05 \times \$ 100,000)$. The average risk of loss associated with lending that amount to other firms would be $\$ 4750(.05 \times \$ 95,000) .{ }^{108}$

Since there is an $80 \%$ chance that a randomly chosen firm will turn out to have fully encumbered assets, the expected loss associated with lending $\$ 100,000$ to any firm would therefore be $\$ 4950 .^{109}$ Thus, if trade suppliers extended $\$ 100,000$ of credit to firms without investigating their capital

105. See Mitchell A. Petersen \& Raghuram G. Rajan, The Benefits of Lending Relationships: Evidence from Small Business Data, 49 J. FiN. 3, 23-25 (1994).

106. See Douglas G. Baird, Security Interests Reconsidered, 80 VA. L. REV. 2249, 2259 (1994); LoPucki, supra note 8, at 1936.

107. This example is intended to reflect the fact that, in the United States, general unsecured creditors can expect to receive nothing in bankruptcy $80 \%$ of the time and an average of $4-5 \not$ on the dollar $20 \%$ of the time. See supra note 18.

108. The average amount lost in the event a partially encumbered firm fails is only $\$ 95,000$ since a creditor owed $\$ 100,000$ would on average receive a payment of $\$ 5000$ in bankruptcy.

109. In lending to a randomly chosen firm, there is an $80 \%$ chance that the risk of loss will be $\$ 5000$ and a $20 \%$ chance that the risk of loss will be $\$ 4750$. Thus, the expected loss is $\$ 4950((.80 \times \$ 5000)+$ (.20 x \$4750)). 
structures, they would be fully compensated for their risk of loss by charging an interest rate that reflected an expected loss of $\$ 4950$. In such a case, trade suppliers would be undercompensated for their risk of loss by $\$ 50$ in $80 \%$ of their transactions and overcompensated for their risk of loss by $\$ 200$ in $20 \%$ of their transactions.

To see why it would not be rational for these trade suppliers to attempt to discriminate between the two types of borrowers, suppose that the market interest rate reflected an expected risk of loss of $\$ 4950$. Assuming that a trade supplier could costlessly find another potential customer, it might consider the strategy of investigating the financial structure of each potential customer and then refusing to extend credit if it determines that the customer's assets are totally encumbered. In $80 \%$ of the potential transactions, the trade supplier would save $\$ 50$. Thus, the expected benefit to the trade supplier of conducting each investigation would be $\$ 40(.80 \times \$ 50)$. However, the transaction costs involved in determining the extent to which a particular firm had encumbered its assets would easily exceed the expected benefit of such an investigation. Thus, the trade supplier-like other trade suppliers-would simply charge an interest rate that reflected the average risk of loss of lending $\$ 100,000$ to companies like Firm.

As a result, when Firm decides whether to encumber all of its assets, it knows that creditors with small claims will not increase the interest they charge if it decides to do so. Like $80 \%$ of similar businesses, Firm may find that it is worthwhile to encumber all of its assets-in part because it can reduce its interest expense by "selling" some of the bankruptcy value that otherwise would belong to trade suppliers of the secured creditor. In such a case, creditors with small claims that charge Firm the average interest rate will be undercompensated by $\$ 50$ for the risk of loss associated with lending to Firm. However, like $20 \%$ of the other businesses in the industry, Firm may find that it is not worthwhile to encumber all of its assets-despite the fact that by doing so it can sell bankruptcy value to a secured creditor. In such a case, creditors charging Firm the average interest rate will be overcompensated by $\$ 200$ for the risk of loss from lending to Firm. It is therefore possible for creditors with small claims to charge an interest rate that fully compensates them for their risk of loss even though they do not adjust their interest rate to take into account the creation of particular security interests.

\section{Prior Voluntary Creditors}

We have just seen that voluntary creditors with small claims will generally find it rational to be nonadjusting with respect to security interests created by their borrowers. There is another category of voluntary creditors that would be nonadjusting with respect to particular security interests: creditors with unsecured claims-no matter how large-that extend credit on fixed terms 
before the borrower makes a decision whether or not to create those security interests. To the extent that the terms set by the creditors are fixed, such creditors, no matter how commercially sophisticated, will not be able to adjust with respect to any security interest subsequently created by the borrower.

One might wonder why unsecured creditors simply do not prohibit borrowers from subsequently issuing secured debt through the use of negative pledge covenants - covenants that severely restrict the ability of a borrower to issue secured debt. ${ }^{\text {I0 }}$ Indeed, we will see that sophisticated creditors frequently negotiate such covenants. ${ }^{11}$ Nevertheless, there are many situations in which a negative pledge covenant will not be used evền if the borrower is likely to issue an inefficient security interest.

First, an unsecured lender might not be willing to offer a lower interest rate in exchange for a negative pledge covenant from a borrower if the transactions of that borrower may be difficult to monitor. Consider the case of an unsecured creditor lending to the typical U.S. firm-a small or mediumsized privately held company. If the firm experiences severe financial problems, ${ }^{112}$ even otherwise honest owner-managers will have a strong incentive to violate covenants if they believe such actions are necessary to keep the firm alive. ${ }^{\text {II3 }}$ The owners may thus disregard a negative pledge covenant and have their company borrow from family, friends, or business associates on a secured basis. Since the "informal" creditor need not perfect its security interest for its claim to have priority over that of the unsecured lender, ${ }^{114}$ there is little risk that the unsecured creditor will discover the borrowing. ${ }^{115}$ When it eventually discovers the breach, the unsecured creditor's only recourse will generally be to call a default, sue for repayment, and then begin the lengthy judicial process required before the creditor can attempt to satisfy its debt by seizing whatever is left of the company's assets

110. The creditor could achieve effects similar to that of a negative pledge covenant by including a "due-on-encumbrance" clause-a clause requiring that the loan be repaid if the borrower issues secured debt—or by a provision requiring the borrower to pay a prohibitive penalty for issuing secured debt (through a much higher interest rate, or otherwise). The analysis of negative pledge covenants that follows thus generally applies to these types of provisions as well.

111. See infra Section VII.B.

112. Smaller firms are more likely to experience financial distress and fail than are larger firms. See Leeth \& Scott, supra note 4 , at 383.

113. See Adler, supra note 23, at 80; Scott, supra note 6, at 946.

114. See U.C.C. \$ 9-201 (1994); id. 9-301.

115. See LoPucki, supra note 8, at $1928 \mathrm{n.157}$; Schwartz, Theory, supra note 23, at 244-45. Indeed, there is anecdotal evidence that unsecured lenders believe that it is too expensive to perform UCC searches routinely in order to learn whether security interests have been perfected in the assets of their borrowers. See MANN, supra note 4. at 20. Thus. the "informal creditor" may even be able to perfect its security interest without discovery by the negative pledge covenant borrower. In contrast, an unsecured creditor lending to a publicly traded firm would quickly learn of such borrowing, since federal law would require the managers of such a firm to disclose any material, privately arranged loan in its next periodic report to the SEC. See Adler, supra note 23, at 92 n.73. 
after the "informal" creditor has been paid. ${ }^{116}$ The process of getting a judgment-which must be obtained before the creditor can seize the firm's assets-may take months or even years. ${ }^{117}$ If an unsecured creditor believes a negative pledge covenant is not enforceable, it will simply set its interest rate to reflect the fact that the firm may later create security interests, thereby subordinating its claim; the firm will then be free to create security interests, even if they are inefficient.

Another reason why a negative pledge covenant may not be used is that the unsecured creditor can never capture all of its benefits. Consider the case of an unsecured creditor lending to a borrower that has nonadjusting creditors. As we will see in Part VII, a portion of the benefits of any negative pledge covenant negotiated by a creditor and a borrower flow to nonadjusting creditors and thus are not captured by the contracting parties. ${ }^{118}$ Since the unsecured creditor and the borrower would bear all of the costs but not enjoy all of the benefits, it would not be in their interest to adopt a negative pledge covenant if their share of the benefits was less than the costs associated with the covenant, even if the total benefits of the covenant would exceed those costs. Thus, there are situations where a negative pledge covenant is not adopted, even if it would be both enforceable and efficient.

Finally, a negative pledge covenant may not be used because it is overbroad. Consider the case of an unsecured creditor lending to a borrower that anticipates issuing both efficient and inefficient security interests. It would not be in the interest of such a borrower to issue a negative pledge covenant if the cost to the borrower of preventing the creation of efficient security interests would exceed the benefit that accrues to it from preventing the creation of inefficient security interests. In such a case, even if the negative pledge covenant were enforceable and all of the costs and benefits associated with the covenant flowed to the creditor and the borrower, it would not be in the interest of the borrower to issue it.

One might question why a sophisticated unsecured creditor not protected by a negative pledge covenant would lend on fixed terms when there is a possibility that the borrower will subsequently issue secured debt subordinating its claim. In principle, the creditor could build an adjustment mechanism into its contracts that would require the borrower to compensate it for its increased risk of loss every time the borrower issues a security interest. Such an adjustment mechanism would permit the borrower to create a security interest transferring value from nonadjusting creditors as long as the sophisticated

116. The security interest of the informal creditor will generally give it priority over the unsecured lender. See Equitable Trust Co. v. Imbesi. 412 A.2d 96 (Md. 1980) (holding that mortgagee had priority in property encumbered by borrower in violation of covenant); MANN, supra note 4, at 20.

117. See LoPucki, supra note 8, at 1935 n.175.

118. See infra Section VII.B. 
creditor is compensated. Thus, an adjustment mechanism might be more likely to be adopted than a negative pledge covenant.

Although some sophisticated creditors may attempt to build such mechanisms into their loan contracts, such arrangements are generally not practical. $^{119}$ The appropriate adjustment factor for each security interest would depend on numerous parameters, such as the likelihood of the borrower's insolvency. Bargaining over the size of the adjustment factor each time the borrower created a security interest would be expensive. And since many of the relevant parameters would be realized only at the time the security interest is created, it would be extremely difficult to specify the appropriate schedule of adjustments in advance. ${ }^{120}$

Moreover, such a contractual provision-like a negative pledge covenant-might be difficult to enforce against smaller companies. Since such companies are easily able to conceal financing transactions, it may take time for an adjustment-clause creditor to learn of the creation of a security interest. ${ }^{121}$ In addition, the company may lack the funds to pay the adjusted rate once the transaction is discovered. Thus, even if an appropriate adjustment schedule could be costlessly specified in advance, there would be situations where a sophisticated creditor would not reduce the interest rate it charged a borrower in exchange for such an adjustment mechanism.

In short, there will be situations where even a sophisticated creditor extending a significant amount of credit will neither bargain for a negative pledge covenant nor incorporate an adjustment mechanism into the loan contract. In such cases, the creditor will not be able to adjust to the subsequent creation of a security interest by the borrower. When the borrower considers creating a security interest, it will thus treat the claims of these prior creditors-like the claims of every other nonadjusting creditor-as fixed.

It should again be emphasized that, although certain prior voluntary creditors may be nonadjusting, we are not assuming that they are undercompensated for the extra risk of loss caused by security interests through the subordination of their bankruptcy claim. For purposes of our analysis, we are willing to assume that prior creditors anticipate the risk that subsequent security interests will subordinate their claims in bankruptcy and charge accordingly. ${ }^{122}$ The only assumption on which our analysis depends is that

119. See, e.g., Kanda \& Levmore, supra note 23, at 2112 (describing high transaction costs of variable-interest-rate arrangements).

120. To be sure, the parties need not get the adjustment factors exactly right for the mechanism to be somewhat effective. But to the extent the adjustment factors are too low, the borrower will still have an incentive to create inefficient security interests that divert value from the unsecured creditor and reduce the joint wealth of the two parties. And to the extent the adjustment factors are too high. the borrower will be prevented from creating security interests that would increase the joint wealth of the two parties. Thus, there would be a cost to the parties from adopting an inaccurate adjustment mechanism (in addition to the costs of contracting for such an arrangement).

121. See supra note 115 and accompanying text.

122. See supra Subsection IV.C.3. 
the terms negotiated by almost all prior creditors, however set, are fixed before the borrower and a potentially secured creditor negotiate their loan transaction. Thus, when the borrower and the potentially secured creditor shape their arrangement, the use of a security interest giving the creditor a secured claim with full priority may make the borrower better off by allowing it to "sell" to the creditor bankruptcy value that would otherwise be enjoyed by these prior nonadjusting creditors.

\section{Full Priority and the Decision to Create a Security Interest}

We are now ready to consider how, under the rule of full priority, the presence of nonadjusting creditors affects the borrower's and a potentially secured creditor's decision about whether to create a security interest. To that end, we provide an extended numerical example that will illustrate the effect of full priority on the arrangement chosen by the borrower and the creditor.

Suppose that Firm is negotiating with Bank for a $\$ 1$ million loan. Assume that two nonadjusting creditors each have already extended $\$ 500,000$ of unsecured credit to Firm, and that one adjusting creditor will extend another $\$ 1$ million of unsecured credit to Firm after the transaction with Bank is completed. ${ }^{123}$ Assume further that Firm has three assets that it could offer Bank as collateral, and that, if Firm does not encumber any of the assets in favor of Bank, $\$ 450,000$ of assets would be available to satisfy creditors' claims in the event of default. Finally, suppose that, whether or not Firm provides any of these assets to Bank as collateral, the probability that Firm will fail by the end of the year is $5 \%$.

Suppose that if Firm encumbers the first asset-which is expected to have a value of $\$ 400,000$ in the event of bankruptcy-the amount of bankruptcy assets available to the creditors as a group would increase from $\$ 450,000$ to $\$ 660,000$. Assume also that encumbering the first asset would cost Bank $\$ 2000$ in contracting costs and reduce shareholders' ability to enrich themselves through asset dilution by $\$ 7500$. On these assumptions, encumbering the first asset would increase the value of creditors' claims (including Bank's) by $\$ 10,500^{124}$ while imposing $\$ 9500$ of costs on Bank and Firm, leading to an efficiency gain of $\$ 1000$.

Suppose that, once Firm has encumbered the first asset, the effect of encumbering the second asset-which is expected to have a value of $\$ 200,000$ in bankruptcy - would be to increase the amount of assets available in the event of bankruptcy to $\$ 720,000$. Assume that encumbering the second asset

123. For convenience, we continue to assume in our numerical examples that shareholders make all interest payments to creditors at the time credit is extended.

124. The increase in the value of creditors' claims is equal to the probability of bankruptcy (5\%) multiplied by the increase in the amount of assets that will be available to creditors in that event $(\$ 660,000-\$ 450,000=\$ 210,000)$, or $\$ 10,500$. 
would cost Bank an additional $\$ 1000$ in contracting costs while reducing the shareholders' ability to engage in asset dilution by an additional $\$ 1000$. In such a case, the effect of including the second asset in Bank's security interest would increase the value of all of the creditors' claims by $\$ 3000^{125}$ while imposing $\$ 2000$ of costs on Bank and Firm, leading to a further efficiency gain of $\$ 1000$.

Finally, suppose that, once Firm has encumbered the first two assets, encumbering the third asset-which is expected to have a value of $\$ 120,000$ in bankruptcy - would have no effect on the total value of assets available to creditors in the event of bankruptcy. In other words, the third asset would be available to satisfy creditors' claims in bankruptcy whether or not it is encumbered as collateral for Bank's loan. Assume that including the third asset in the security interest would cost Bank an additional $\$ 1000$ in contracting costs (but impose no costs on Firm's shareholders). Thus, encumbering the third asset would lead to an efficiency loss of $\$ 1000$.

Let us now consider the incentives faced by Firm under the rule of full priority. If Firm does not encumber any of the assets, Bank and the adjusting creditor would receive $\$ 150,000$ each, and the two nonadjusting creditors would receive $\$ 75,000$ each in the event of bankruptcy. ${ }^{126}$ By pledging the first asset to Bank, Firm would increase Bank's share of bankruptcy assets from $\$ 150,000$ to $\$ 460,000$ while reducing the adjusting creditor's share of bankruptcy assets from $\$ 150,000$ to $\$ 100,000 .{ }^{127}$ Since taking a security interest in the first asset would cost Bank $\$ 2000$ in contracting costs but reduce its risk of loss on the loan by $\$ 15,500,{ }^{128}$ Bank would charge Firm $\$ 13,500$ less in interest if the first asset were provided as collateral. However, the adjusting creditor would charge $\$ 2500$ more in interest, ${ }^{129}$ so that the net

125. The increase in the value of creditors' claim is equal to the probability of bankruptcy (5\%) multiplied by the increase in the amount of assets that will be available to creditors in that event $(\$ 720,000-\$ 660,000=\$ 60,000)$, or $\$ 3000$.

126. Recall that if Firm does not create a security interest in favor of Bank, $\$ 450,000$ would be available in the event of bankruptcy to satisfy creditors' claims. Bank and the adjusting creditor would be owed $\$ 1$ million each, and the two nonadjusting creditors would be owed $\$ 500,000$ each by Firm, for a total of $\$ 3$ million in liabilities. The payout rate for unsecured claims would thus be $(\$ 450,000 / \$ 3$ million), or $15 \phi$ on the dollar. With no security interest, Bank would thus lose $\$ 850,000$ in the event of bankruptcy.

127. Under the rule of full priority, if Firm encumbers the first asset, Bank would have a secured claim in bankruptcy for $\$ 400,000$ (the expected value of the first asset) and an unsecured claim for $\$ 600,000$ (the balance of the $\$ 1$ million owed Bank). Bank's $\$ 600,000$ unsecured claim would share pro rata with the $\$ 2$ million of other unsecured claims in the $\$ 260,000$ of assets that remain after Bank's $\$ 400,000$ secured claim is paid. Unsecured claims would therefore be paid $10 \phi$ on the dollar. Bank would receive $\$ 60.000$ for its unsecured claim (for a total bankruptcy payment of $\$ 460,000$ ), and the adjusting creditor would receive $\$ 100,000$ for its unsecured claim. With a security interest in the first asset, Bank would thus lose $\$ 540,000$ in the event of bankruptcy.

128. In the absence of a security interest. Bank would lose $\$ 850.000$ in the event of bankruptcy. See supra note 126. If the first asset were provided to Bank as collateral, Bank would lose only $\$ 540,000$ in the event of bankruptcy. See supra note 127 . Thus, encumbering the first asset would reduce Bank's expected loss by $\$ 15,000((.05 \times \$ 850,000)-(.05 \times \$ 540,000))$.

129. If there is no security interest, the adjusting creditor would lose $\$ 850,000$ in the event of bankruptcy. See supra note 126 . If the first asset is given to Bank as collateral, the adjusting creditor would 
reduction in interest faced by Firm would be only $\$ 11,000$. Since pledging the first asset to Bank would reduce shareholders' ability to enrich themselves through asset dilution by only $\$ 7500$, Firm would have an incentive to provide the first asset as collateral.

If Firm provides the second asset as collateral (in addition to the first), Bank's share of bankruptcy assets would increase from $\$ 460,000$ to $\$ 620,000$, and the adjusting creditor's share of bankruptcy assets would decrease from $\$ 100,000$ to $\$ 50,000 .{ }^{130}$ Since encumbering the second asset would cost Bank $\$ 1000$ in contracting costs but reduce its risk of loss on the loan by $\$ 8000,{ }^{131}$ Bank would charge Firm $\$ 7000$ less interest if the second asset were also provided as collateral. However, the adjusting creditor would charge another $\$ 2500$ in interest, ${ }^{132}$ so that the net reduction in interest faced by Firm would be $\$ 4500$. Since the effect of pledging the second asset would be to reduce the ability of shareholders to engage in asset dilution by only an additional $\$ 1000$, Firm would have an incentive to encumber the second asset.

Finally, if Firm also offers the third asset as collateral, Bank's share of bankruptcy assets would increase from $\$ 620,000$ to $\$ 720,000$, and the adjusting creditor's share would decrease from $\$ 50,000$ to zero. Since encumbering the third asset would cost Bank an additional $\$ 1000$ in contracting costs while reducing its risk of loss by $\$ 5000$, Bank would be willing to charge Firm $\$ 4000$ less in interest if the third asset is also provided as collateral. Encumbering the third asset would cause the adjusting creditor to charge another $\$ 2500$ in interest. Thus, even though encumbering the third asset would be inefficient, Firm would have an incentive to do so under the rule of full priority. ${ }^{133}$

The reason Firm is better off inefficiently pledging the third asset is that nonadjusting creditors will not raise their interest rates to take into account the effect of encumbering that asset on them. The pledging of each asset reduces the payment to unsecured claims by $5 \phi$ on the dollar. Thus, the value of the nonadjusting creditors' claims is reduced by $\$ 2500$ each time an asset is encumbered. ${ }^{134}$ Since the pledging of each asset reduces the value of the two

lose $\$ 900,000$ in the event of bankruptcy. See supra note 127 . Thus, encumbering the first asset would increase the adjusting creditor's expected loss by $\$ 2500((.05 \times \$ 900,000)-(.05 \times \$ 850,000))$.

130. Under the rule of full priority, Bank would have a secured claim for $\$ 600,000$ (representing the combined value of the two encumbered assets) and an unsecured claim for $\$ 400,000$. Bank's unsecured claim would share pro rata with the $\$ 2$ million of other unsecured claims in the $\$ 120,000$ that would remain after Bank's $\$ 600,000$ secured claim is paid. Unsecured claims would thus be paid $5 \notin$ on the dollar. As a result, Bank would receive $\$ 20,000$ on its unsecured claim (for a total of $\$ 620,000$ ), and the adjusting creditor would receive $\$ 50,000$ on its $\$ 1$ million unsecured claim.

13I. Bank's expected loss would decrease by $\$ 8,000((.05 \times \$ 540,000)-(.05 \times \$ 380,000))$.

132. The adjusting creditor's expected loss would increase by $\$ 2500((.05 \times \$ 950,000)-(.05 \times$ $\$ 900,000)$ ).

133. By encumbering the third asset, Firm would reduce the interest charged by Bank and the adjusting creditor by $\$ 1500(\$ 4000-\$ 2500)$.

134. Each time an asset is encumbered, the payment to unsecured claims is reduced by $5 \notin$ on the dollar. Since the nonadjusting creditors are owed $\$ 1$ million, their combined bankruptcy share is reduced 
nonadjusting creditors' claims by a total of $\$ 2500$, the creation of the security interest in the three assets would transfer $\$ 7500$ of value from these creditors to Firm.

Let us now consider whether the nonadjusting creditors are actually "hurt" by the creation of the security interest in the three assets. We will examine four cases. First, consider the case in which all of the nonadjusting creditors are involuntary creditors (such as tort creditors). Since the involuntary creditors do not have the opportunity to set the size of their claims to reflect the possibility of this $\$ 7500$ transfer, they would actually be "hurt" by the creation of the security interest in the three assets.

The second case to be considered is one in which all of the nonadjusting creditors are voluntary creditors whose claims against Firm are small. ${ }^{135}$ As explained, creditors with small claims, such as trade suppliers, may set their interest rates to reflect the average risk of loss from lending to businesses such as Firm. In such a case, they will not be "hurt" on average by extending credit to businesses like Firm. ${ }^{136}$ However, the interest rate charged a particular business may not compensate these creditors for their risk of loss. If the interest charged Firm does not compensate them for their risk when Firm encumbers all three assets, the creation of the security interest in the three assets will "hurt" these creditors.

The third case is one in which all of the nonadjusting creditors are sophisticated and have large claims against Firm. Let us assume, for example, that the nonadjusting creditors are insurance companies that extend credit to Firm before its transaction with Bank. If these insurance companies believe at the time they extend credit to Firm that Firm is likely to encumber all three assets, the insurers will choose terms that compensate them for the anticipated transfer of $\$ 7500$. When Bank and Firm later negotiate their loan contract, Firm will encumber all three assets as expected by the insurance companies. Because the insurers will be compensated for subordination by the higher interest rate paid by Firm, they will not be "hurt" by the creation of the security interests. Thus, when all of Firm's nonadjusting creditors are voluntary and well informed, the efficiency costs arising from the anticipated encumbering of the third asset will be borne entirely by Firm's equityholders when they pay interest to these creditors.

In the case in which all of a firm's nonadjusting creditors are voluntary and well informed, one might think that a firm would be better off contracting in advance not to inefficiently encumber any asset. However, such a

$\$ 50,000$ each time an asset is encumbered, increasing their expected loss by $\$ 2500(.05 \times \$ 50.000)$. As there is a $5 \%$ chance of bankruptcy, the expected value of these creditors' claims is thus reduced by $\$ 2500$ $(.05 \times \$ 50,000)$ every time an asset is encumbered.

135. Assume that the two nonadjusting creditors owed $\$ 500,000$ each are instead 20 nonadjusting trade creditors each owed $\$ 50,000$.

136. See supra Subsection IV.C.3. 
commitment would require that the firm know in advance that it would be inefficient to encumber particular assets. Under the reasonable assumption that it is difficult to acquire this knowledge in advance, it would not be in a firm's interest to make such a commitment because it might prevent it from creating an efficient security interest.

It might also be argued that, in the case in which all of a borrower's nonadjusting creditors are voluntary and well informed, the borrower would be constrained from inefficiently encumbering an asset by the need to protect its reputation. However, even well-informed creditors are unlikely to know whether encumbering a particular asset would be efficient or inefficient. Moreover, since businesses in the borrower's industry will tend to act similarly, the borrower's use of particular security interests is not likely to be unconventional or unanticipated. The borrower's reputation will, therefore, be no better or worse than those of its competitors if it inefficiently encumbers an asset.

Returning to our example, let us consider the fourth (and most realistic) case-that in which only some of Firm's nonadjusting creditors are voluntary and well informed, while the others are either involuntary or rationally uninformed creditors with small claims. In such a scenario, encumbering the third asset might still be in Firm's interest if it transfers enough bankruptcy value from the involuntary or rationally uninformed creditors to make Firm better off. Thus, when some of Firm's creditors are involuntary or rationally uninformed, Firm might be better off retaining the ability to encumber the third asset even when it knows in advance that encumbering that asset would be inefficient.

Whether or not the nonadjusting creditors in this example are compensated for the increased risk of loss due to the creation of the three security interests, what these creditors charge Firm will not be affected by the actual arrangement between Firm and Bank-because they are involuntary, or are rationally uninformed about Firm's arrangement with Bank, or had extended credit before the transaction with Bank. Thus, the use of a security interest providing Bank with full priority in some of Firm's assets will transfer value from these creditors. Consequently, Firm and Bank will have an incentive to encumber assets with a security interest, even if this results in a loss of social value.

\section{EFFICIENCY COSTS OF FULL PRIORITY}

We are now ready to examine systematically five efficiency costs that arise when full priority is accorded to secured claims. The first two efficiency costs are that full priority (1) increases the use of inefficient security interests and (2) increases the use of security interests that are efficient. but less efficient than a set of covenants, and therefore undesirable. Full priority thus causes excessive use of security interests. 
The last three costs-(1) distorted investment and precaution decisions of the borrower; (2) suboptimal use of the covenants by the secured creditor; and (3) suboptimal enforcement efforts by the secured creditor-are prioritydependent efficiency costs of security interests. The effect of these three priority-dependent efficiency costs is to make the use of any given security interest less efficient or more inefficient than it would be in a world without priority. Since these three costs, along with the three priority-independent efficiency costs of security interests described in Part III, may be present whenever a security interest is used under full priority, they would arise even if full priority did not affect the number of security interests used.

\section{A. The Use of Inefficient Security Interests}

As we saw in Part IV, a borrower and a secured creditor may have incentives under full priority to expend resources inefficiently encumbering an asset merely to transfer bankruptcy value from nonadjusting creditors. That is, a borrower and a secured creditor may adopt a security interest that gives the two parties a larger slice of the pie at the expense of nonadjusting creditors even though the security interest at the same time reduces the size of the total pie. This is the first efficiency cost of full priority.

Returning to our hypothetical Firm and Bank, suppose that Firm borrows $\$ 1$ million each from three sources: Bank, a nonadjusting creditor, and an adjusting creditor. Suppose further that there is a 5\% chance that Firm will fail by the end of the year and leave $\$ 600,000$ of assets to its creditors. Assume that to obtain a security interest in the $\$ 600,000$ worth of assets, Bank would be required to spend $\$ 2000$, and that use of the security interest would affect neither the probability of Firm's failure nor the amount of assets that would be available to Firm's creditors in the event of default. Thus, creating the security interest would be inherently inefficient because it would reduce the total value captured by all of the parties by $\$ 2000$.

Consider the case in which the use of a security interest would not confer any priority on Bank's claim. In such a case, Bank and Firm would have no incentive to spend $\$ 2000$ to create the security interest because Bank would receive $\$ 200,000(1 / 3$ of $\$ 600,000)$ in bankruptcy whether or not the security interest had been created. Thus, Bank and Firm would act efficiently under a rule of no priority by choosing not to adopt the security interest.

Now consider the case in which the security interest would confer full priority on Bank's claim against Firm. Under a rule of full priority, the security interest would reduce Bank's risk of loss by $\$ 20,000$ and would increase the other creditors' risk of loss by $\$ 10,000$ each. ${ }^{137}$ Since Bank

137. In the absence of a security interest, each creditor would be entitled to $\$ 200,000$ in bankruptcy and would thus face an expected loss of $\$ 40,000(.05 \times \$ 800,000)$. If Bank had full priority in the $\$ 600,000$ 
would incur $\$ 2000$ in contracting costs in connection with the security interest, and its risk of loss would be reduced by $\$ 20,000$, it would charge Firm $\$ 18,000$ less in interest while the adjusting creditor would charge Firm $\$ 10,000$ more in interest. Thus, full priority will give Firm an incentive to create an inefficient security interest merely to transfer value from its nonadjusting creditors.

\section{B. Distorted Choice Between Security Interests and Covenants}

Full priority may also cause commercial borrowers and their sophisticated creditors to use a security interest that is less efficient than a set of covenants in order to control inefficient behavior by the borrower after the loan transaction.

To illustrate, suppose that Bank and Firm will choose either a set of covenants or a security interest (but not both) to reduce Firm's ability to engage in inefficient asset dilution after the transaction. Suppose that Firm already owes $\$ 1$ million to a nonadjusting creditor, is borrowing $\$ 1$ million from Bank, and will borrow $\$ 1$ million from an adjusting creditor. Suppose further that, if Bank is given a security interest in $\$ 1$ million of assets, $\$ 1.2$ million will be available for distribution to creditors in the event of default, but, if Bank uses a set of covenants designed to prevent Firm's shareholders from engaging in inefficient asset dilution, $\$ 1.5$ million will be available to creditors in the event Firm fails. Finally, assume that both the set of covenants and the security interest would impose the same contracting and opportunity costs on Bank and Firm and that there is a 5\% chance that Firm will fail in either case. Adoption of the set of covenants would clearly be more efficient because, in the event of bankruptcy, creditors would be $\$ 300,000$ better off than if the security interest had been adopted, while shareholders would be no worse off.

If the security interest were created but did not confer priority on Bank's claim, each creditor (including Bank and the adjusting creditor) would receive its pro rata share of $\$ 1.2$ million- $\$ 400,000$-in the event of Firm's bankruptcy. On the other hand, if the set of covenants were adopted, Bank and the adjusting creditor would receive $\$ 500,000$ each-one-third of $\$ 1.5$ million-if Firm fails. As a result, Bank and the adjusting creditor would each charge Firm $\$ 5000$ less interest if Firm issued the set of covenants rather than the security interest. ${ }^{138}$ Thus, Firm would have an incentive to issue the set

of bankruptcy assets through use of a security interest, it would face an expected loss of $\$ 20,000(.05 \times$ $\$ 400,000)$, and the other creditors would each face an expected loss of $\$ 50,000$ (.05 $\$ \$ 1$ million), $\$ 10,000$ more than in the absence of the security interest.

138. The expected loss for each creditor, the probability of bankruptcy multiplied by the expected loss in the event, would be $\$ 25,000(.05 \times \$ 500,000)$ if the covenants were adopted and $\$ 30,000(.05 \times$ $\$ 600,000$ ) if the security interest were used. 
of covenants rather than the security interest to Bank under a rule of no priority.

If the security interest were adopted under the rule of full priority, however, Bank would receive $\$ 1$ million, and the adjusting creditor would receive $\$ 100,000$ in the event of bankruptcy. ${ }^{139}$ Since Bank and the adjusting creditor would each receive $\$ 500,000$ if the set of covenants were adopted, Bank would charge $\$ 25,000$ less interest, and the adjusting creditor would charge $\$ 20,000$ more if Bank were given a security interest. ${ }^{140}$ Since Firm would thus be able to reduce its interest expense by creating the security interest rather than the set of covenants, it would have an incentive to choose the less efficient security interest.

\section{Distorted Investment and Precaution Decisions}

We have just seen that according full priority tc secured claims in bankruptcy causes borrowers and their creditors to use security interests that are not efficient, or efficient but less efficient than a set of covenants, solely to transfer value from nonadjusting creditors.

We now turn to a different category of costs that arises from full priority: costs that may arise whenever a security interest is used under full priority. These priority-dependent efficiency costs make the use of any given security interest less efficient or more inefficient than it would be in the absence of priority. Thus, these costs would arise even if full priority did not affect the overall use of security interests.

The first priority-dependent efficiency cost of security interests is that their use under full priority may distort a borrower's choice of investments and level of precaution. Indeed, as this section will explain, the ability of a borrower to give a creditor a security interest that subordinates the claims of nonadjusting creditors may adversely affect the borrower's behavior even before the borrower and the secured creditor negotiate their loan contract.

Consider the case in which Firm must decide, prior to contracting with Bank, whether to take certain precautions that will make its products safer and thereby reduce the number of future tort claims against Firm. Firm knows that when Bank and Firm later negotiate their loan contract, Bank will take expected tort claims into account in setting its interest rate. Thus, Bank will charge Firm a higher interest rate to the extent it anticipates that future tort

139. Recall that the encumbered assets are worth $\$ 1$ million and total bankruptcy value will be $\$ 1.2$ million. Thus, Bank would receive $\$ 1$ million if Firm fails. The adjusting and nonadjusting creditors would share equally in the $\$ 200.000$ remaining after Bank's $\$ 1$ million secured claim is paid. so that the adjusting creditor would receive $\$ 100,000$.

140. Bank is avoiding an expected loss of $\$ 25,000$ because it will not face the $5 \%$ chance of losing $\$ 500,000$ (the difference between the $\$ 1$ million it receives under full priority and the $\$ 500.000$ it would receive if the covenants were adopted). 
claims will reduce the value of its loan by diluting Bank's share of Firm's bankruptcy assets. To the extent that Bank adjusts its interest rate to take into account future tort claims against Firm, Bank forces Firm to internalize more of the cost of its failure to take precautions. Thus, to the extent that the tort claims reduce the value of Bank's claim, Firm will have a greater incentive to take precautions prior to transacting with Bank.

Under the rule of full priority, however, Firm may give Bank a security interest that more or less protects the value of Bank's loan from being diluted by tort claims. To the extent that Bank is given a security interest that insulates its claim from the effect of Firm's activities, it will not charge a higher interest rate if Firm fails to take precautions and additional tort claims against Firm are expected. And, to the extent Firm does not face the prospect of a higher interest rate if it fails to take precautions, Firm will have less incentive to invest in these precautions. ${ }^{141}$

To illustrate, suppose that Firm intends to borrow $\$ 2$ million from Bank, its only nontort creditor. Suppose further that there is a 5\% chance that Firm will fail by the end of the year, leaving $\$ 1$ million of assets available to satisfy its creditors' claims. Assume that if Firm does not take precautions, there is a 50\% chance that it will face $\$ 8$ million in tort claims by the end of the year, but that if Firm takes precautions, it will not face any tort claims.

If Bank does not have priority in Firm's bankruptcy assets, its expected loss is $\$ 50,000$ if Firm takes precautions, ${ }^{142}$ and $\$ 72,500$ if Firm does not. ${ }^{143}$ Thus, Bank will charge Firm $\$ 22,500$ more in interest if Firm does not take precautions. However, if Bank is given a security interest in the $\$ 1$ million of assets that will be available to satisfy creditors' claims in bankruptcy, the expected value of its bankruptcy claim will be $\$ 1$ million whether or not Firm takes precautions. Thus, Firm will have less incentive to take precautions if creditors' claims can be given priority through use of a security interest.

In essence, the rule of according full priority to secured claims exacerbates the distortions created by limited liability, a problem that has recently attracted considerable academic attention. ${ }^{144}$ As that literature has explained, limited liability allows shareholders to avoid internalizing the full costs imposed on tort victims by limiting the victims' claims to the amount of the borrower's

141. The fact that the use of security interests under full priority permits the borrower to bear less of the cost of claims of tort creditors is well recognized. See Buckley, supra note 23, at 1417: LoPucki, supra note 8, at 1898 .

142. There is a $5 \%$ chance that Firm will fail, causing Bank to lose $\$ 1$ million. Bank's expected loss is thus $\$ 50,000$ (.05 $\times \$ 1$ million).

143. There is a $2.5 \%$ chance that Firm will fail and cause Bank to lose \$1 million, and a $2.5 \%$ chance that Firm will fail and cause Bank to lose $\$ 1.9$ million. Thus, Bank's expected loss is $\$ 72,500((.025 \times \$ 1$ million $)+(.025 \times \$ 1.9$ million $))$.

144. See, e.g.. Hansmann \& Kraakman. supra note 85. at 1909-16: Leebron. supra note 91. at 1646-49: Painter, supra note 91, at 1054-70. 
assets in bankruptcy. This leads firms to underinvest in precautions and overinvest in risky activities that externalize harm to other parties. According full priority to secured claims allows shareholders to avoid internalizing even more of the costs in the manner we have just described. ${ }^{145}$

\section{Suboptimal Use of Covenants}

The second priority-dependent efficiency cost of security interests is that their use, under full priority, may cause a secured creditor to use too few covenants. As we explained in Part IV, in a perfect world in which the terms of other creditors' loan agreements fully reflect the consequences to them of the arrangement between a borrower and a creditor, the two parties would have an incentive to adopt any covenant that is efficient because they would capture all of the resulting benefits. In the real world, however, nonadjusting creditors would capture part of the benefits and bear none of the costs of any set of covenants negotiated between the contracting parties. Consequently, even if the set of covenants were socially optimal because its total benefits exceeded its total costs, it would not be privately optimal for the borrower and the creditor if the benefits accruing to the contracting creditor (and any other adjusting creditors) were less than the costs to the borrower. ${ }^{146}$

While this problem-that a borrower and a creditor will have an insufficient incentive to adopt efficient covenants-generally occurs whenever there are creditors whose claims do not adjust to reflect fully the agreement between the parties, the problem becomes more severe if the borrower and the creditor adopt a security interest under the rule of full priority. In such a case, the creditor's risk of loss-and therefore the benefit to the creditor of an additional set of covenants-will be substantially reduced. ${ }^{147}$ The creditor is thus even less likely under a rule of full priority to adopt a highly efficient covenant. ${ }^{148}$

145. It is worth noting that full priority may well cause other distortions in a firm's investment decisions before the firm issues secured debt. For example, to the extent that the firm has an incentive to offer lenders collateral in order to transfer value from nonadjusting creditors, it may have an incentive to invest in assets that can easily serve as collateral, even if other investments (such as employee training) would offer higher social retums.

146. See Triantis, Secured Debt, supra note 23, at 242.

147. If the creditor's loan is fully secured, and there is sufficient excess collateral to fully cover the creditor's collection costs and any unpaid interest, then its risk of loss will approach zero. $C f$. Hudson, supra note 27, at 51-52 (observing that bank with secured loan will have no incentive to use its knowledge of debtor in socially desirable manner because it is fully protected from risk of loss).

148. The point that a creditor that takes security under a rule of full priority is less likely to "monitor" the debtor through other contractual restrictions is well understood in the literature. See Buckley. supra note 23, at 1440-41; Jackson \& Kronman. supra note 23, at 1153; Triantis, Secured Debt, supra note 23, at 244. For empirical evidence that secured lenders adopt fewer covenants, see Kenneth Lehn \& Annette Poulsen, Contractual Resolution of Bondholder-Stockholder Conflicts in Leveraged Buyouts, 34 J.L. \& ECON. 645, 662 (1991) (reporting that secured bonds contain fewer covenants than unsecured bonds). 
The following numerical example illustrates how full priority exacerbates the problem of the suboptimal use of covenants. Suppose that there is a 5\% chance that Firm will fail, leaving $\$ 1.2$ million in assets to be distributed among Bank, an adjusting creditor owed $\$ 1$ million, and a nonadjusting creditor owed $\$ 1$ million. Firm will give Bank a security interest in collateral expected to be worth $\$ 1$ million in the event of bankruptcy. Now Bank and Firm are considering adopting a set of covenants designed to prevent Firm from engaging in overinvestment. Adoption of this set of covenants would reduce the likelihood of Firm failing from $5 \%$ to $4 \%$, but reduce the shareholders' ability to enrich themselves by (an expected value of) $\$ 9500$. Since creditors as a group will lose $\$ 1.8$ million if Firm fails, reducing the probability of failure by $1 \%$ would increase the expected value of creditors' claims by $\$ 18,000$. Adoption of the set of covenants would thus increase the value captured by all of the parties by $\$ 8500$ ( $\$ 18,000$ less $\$ 9500)$ and therefore would be efficient.

Let us first consider the case in which the security interest granted Bank does not confer priority on its claim. In such a case, Bank and the adjusting creditor would each receive $\$ 400,000$ of the $\$ 1.2$ million of assets available to creditors in the event of default. If the overinvestment covenants were adopted, thereby reducing the probability of default by $1 \%$, the expected value of these creditors' claims would each increase by $\$ 6000 .{ }^{149}$ Firm would therefore have an incentive to offer Bank the overinvestment covenants since the resulting reduction in interest charged Firm, i.e. $\$ 12,000$, would be greater than the cost to Firm's shareholders of foregoing the opportunity to overinvest, i.e. $\$ 9500$.

Now let us consider the case in which the security interest confers priority on Bank's claim. In such a case Bank would receive $\$ 1$ million in the event of failure, and the adjusting creditor would receive $\$ 100,000$. Reducing the probability of failure by $1 \%$ would increase the expected value of the adjusting creditor's claim by $\$ 9000$ but not affect the expected value of Bank's claim. The overinvestment covenants under the rule of full priority would lead the adjusting creditor to reduce the interest it charges Firm by $\$ 9000$, but would cost Firm's shareholders $\$ 9500$. Therefore, it would not be in Firm's interest to offer Bank the overinvestment covenants, even though they would be efficient.

The general problem illustrated by this example-that a secured creditor has less incentive to control the borrower's behavior to the extent that a security interest giving it full priority reduces its risk of loss-also gives rise to the third priority-dependent efficiency cost of security interests described below. As we shall see, the use of a security interest under full priority may

149. The expected loss faced by each creditor would decrease by $\$ 6000((.05 \times \$ 600,000)-(.04 \times$ $\$ 600,000)$ ). 
lead to suboptimal control of the borrower even if it does not distort the secured creditor's use of covenants.

\section{E. Suboptimal Enforcement Efforts}

We have seen that, in the presence of nonadjusting creditors, the use of a security interest under full priority may cause inefficiencies by inducing the parties to forego the use of desirable covenants once a security interest is adopted. Now let us consider the case in which the use of a security interest under full priority has no effect on the parties' adoption of covenants. ${ }^{150}$ As we shall see, even in this case, in which the parties adopt covenants restricting borrower misbehavior, the use of the security interest under full priority will permit the borrower to act more inefficiently following the extension of credit.

In analyzing the effect of full priority on the use of covenants in loan arrangements, we abstracted from the level of a creditor's enforcement efforts-the activities undertaken by the creditor to ascertain whether the borrower is continuing to comply with its contractual commitments. However, as was explained in Part IV, a borrower's incentive to comply with the covenants it has issued may well depend upon the level of the creditor's enforcement efforts. That is, the less the creditor monitors the borrower's compliance with its covenants, the less likely the creditor will detect a breach, and the more likely the borrower will find the expected cost of breach to be less than the expected benefit of breach. To the extent the covenants bar the borrower from engaging in inefficient activities, the level of the creditor's enforcement efforts will therefore have efficiency implications.

Even in the absence of full priority, a creditor will engage in less than the optimal amount of enforcement activity since some of the benefit of this activity will flow to other creditors, while it (and the borrower) will bear all of the costs. But the creditor will have even less of an incentive to engage in enforcement activities to the extent that it is protected from risk of loss by a security interest giving the creditor's claim full priority in bankruptcy-just as it will have less of an incentive to adopt even highly efficient covenants. As a result, a borrower may be more likely to violate a covenant and to act inefficiently when its sophisticated creditors have security interests giving them full priority in their collateral. Thus, even if full priority does not cause a borrower and a creditor to adopt fewer covenants, it may well degrade the effectiveness of the covenants they do adopt-and lead to efficiency

150. This situation might arise. for example, in the case where a bank uses the same standardized loan contract whenever it extends credit to a particular class of borrowers, whether or not it also takes a security interest. 
problems-by reducing the creditor's incentive to monitor the borrower's compliance with those covenants. ${ }^{151}$

The priority-dependent efficiency costs arising from the use of a security interest are of course especially high when the secured creditor is a sophisticated lender such as a bank. A bank will typically be quite knowledgeable about a borrower to which it has extended a significant amount of credit. And, by virtue of its sophistication, resources, and leverage, the bank will be able to exert a significant amount of influence over the borrower. ${ }^{152}$ Indeed, a bank will frequently determine whether or not a borrower files for bankruptcy and the timing of any filing. ${ }^{153}$ Thus, the bank is in a unique position to control a borrower's behavior. However, to the extent that the bank is insulated by a security interest from the effects of the borrower's misbehavior, the bank will have less incentive to control the borrower's behavior. ${ }^{154}$

Of course, the tendency of full priority to cause secured creditors to adopt too few covenants and to suboptimally enforce the obligations of their borrowers would not be a cause of great concern if the borrowers had unsecured creditors that were capable of similar monitoring. However, the empirical data on the financing arrangements of privately held small and medium-sized firms-the issuers of most secured debt ${ }^{155}$-indicate that such firms almost always have only one institutional creditor (e.g., a bank or finance company) that is capable of general monitoring. ${ }^{156}$ (This pattern is also seen in bankruptcy: The vast majority of all bankruptcy cases involve a debtor with a principal secured creditor and many small (usually trade) creditors. ${ }^{157}$ ) Thus, to the extent that one institutional creditor is insulated from risk of loss by using a security interest giving it full priority, the borrower will be free to misbehave.

151. The problem that a fully secured creditor will not have a sufficient incentive to monitor the borrower is recognized even by those who support the rule of full priority. See, e.g., Buckley, supra note 23, at 1440-41. Since all contracts between commercial borrowers and their creditors implicitly incorporate the various mandatory rules that govern the relationship between debtors and creditors, such as fraudulentconveyance law and corporate law limitations on payments to shareholders, the problem of suboptimal monitoring will arise even if the two parties do not adopt their own privately negotiated covenants.

152. See Hudson, supra note 27, at 51-52; Scott. supra note 6, at 925-33.

153. See Bufford, supra note 89 , at 834-35.

154. See Adler, supra note 23, at 83, 88, 92-93; Buckley, supra note 23, at 1469.

155. See Scott, supra note 6, at 940; supra text accompanying notes 5-6.

156. See Petersen \& Rajan, supra note 105 , at 16 (noting that $82 \%$ of sample of firms borrowed from only one bank); Scott, supra note 6, at 949 (reporting that standard commercial-finance security agreement provides "that the lender will act as the borrower's "sole source of financing," and that less than 5\% of sample of small businesses developed general financing arrangement with more than one creditor). Larger. publicly traded firms may borrow from more than one sophisticated creditor, but they generally do not issue secured debt. See Booth. supra note 5, at 29, 39-41.

157. See Bufford, supra note 89 , at 834-35. 


\section{POSSIBLE Alternatives TO FULl PRIORITY}

We have seen that a rule of full priority for secured claims leads to certain inefficiencies in the presence of nonadjusting creditors. In particular, full priority gives rise to priority-dependent efficiency costs that increase the total cost associated with the use of security interests, and it causes borrowers and their sophisticated creditors to increase their use of inefficient security interests.

In this part we present two rules that would reduce or eliminate these inefficiencies by providing only partial priority to secured claims. ${ }^{158}$ The first partial-priority rule presented, the "adjustable priority rule," works by denying secured claims priority over the claims of nonadjusting creditors. This approach, if properly implemented, would eliminate all of the inefficiencies associated with full priority that we identified. Under the second partial-priority rule, the "fixed-fraction priority rule," a fixed fraction of each secured claim would be treated as an unsecured claim. Both rules would have the effect of leaving all secured creditors at least partially unsecured. ${ }^{159}$

Neither of these partial-priority rules would be superior in every respect to the rule of full priority. As Part VII will explain, there would be efficiency costs associated with these rules-or any rule of partial priority - that must be weighed against the benefits these rules would provide. However, three points need to be emphasized before we examine the rules in detail. The first is that neither of these rules would completely eliminate the priority accorded to secured claims over unsecured claims in bankruptcy. The partial-priority rules would affect only the degree to which the secured creditor enjoys priority in its collateral over the claims of unsecured creditors when the debtor enters bankruptcy. Second, a secured creditor would continue to enjoy full priority in bankruptcy over the claims of any junior secured creditors in the same assets. The third and most important point is that neither of these priority rules would have any effect on the secured creditor's "repossessory right" and statelaw "priority right" outside of bankruptcy. That is, neither alternative would be inconsistent with Article 9 of the UCC or current state laws governing transactions in real property. Thus, the operation of security interests outside bankruptcy would be completely unaffected by either rule.

158. It should be emphasized that these partial-priority rules are not designed to eliminate or reduce all of the efficiency distortions in loan contracts between commercial borrowers and their lenders-only those that arise as a result of the rule of full priority. Nor are these rules intended for use in consumer bankruptcy cases where the individual was not engaged in a business before going bankrupt.

159. Recall that the secured claim is the lesser of (1) the amount owed the lender and (2) the value of the collateral securing the claim. A secured creditor that takes a security interest in assets worth more than the amount of the loan would therefore have a secured claim no greater than the amount of its loan. By tuming part of every secured claim into an unsecured claim, the partial-priority rules would ensure that every secured creditor is partially unsecured. 


\section{A. The Adjustable-Priority Rule}

As we have seen, a serious problem with the rule of full priority is that it allows a borrower to transfer value from creditors that do not adjust their claims to reflect the terms of the borrower's relationship with a secured creditor. This transfer of value in turn leads to the various inefficiencies described in Part V. The adjustable-priority rule, which would deny a secured claim priority over the claims of creditors that were nonadjusting with respect to the security interest underlying the secured claim, would be a natural alternative to full priority because it goes directly to the root of the problem that arises under that rule.

One might question whether a bankruptcy court could in fact identify those creditors of a debtor that were nonadjusting with respect to a particular security interest in order to enforce such a rule. We will address the feasibility of implementing the adjustable-priority rule shortly. For the moment, however, let us assume that the court would be able to identify a debtor's nonadjusting creditors to examine how the rule would work under ideal conditions.

Suppose that our hypothetical Firm goes bankrupt with $\$ 1.2$ million in assets and outstanding liabilities of $\$ 3$ million, $\$ 1$ million of which is owed to Bank, $\$ 1$ million of which is owed to an adjusting unsecured creditor, and $\$ 1$ million of which is owed to a nonadjusting creditor. Assume further that $\$ 1$ million of the assets are subject to a security interest held by Bank.

In the absence of any priority, the $\$ 1.2$ million in assets would be divided on a pro rata basis with each creditor receiving $\$ 400,000 .{ }^{160}$ Under the rule of full priority, and assuming that all unsecured creditors share pro rata in the remaining assets, Bank would receive $\$ 1$ million and the remaining $\$ 200,000$ in assets would be divided equally between the other two creditors. The result under full priority would be that $\$ 300,000$ of bankruptcy value is transferred from each unsecured creditor to Bank, the secured creditor. Bank thus benefits under the full-priority rule at the equal expense of both the adjusting and the nonadjusting creditor.

Under the adjustable-priority rule, claims of nonadjusting creditors would not be subordinated to secured claims with respect to which they were nonadjusting. The adjustable-priority rule would require that, when applying the rule of full priority, a nonadjusting creditor's share of bankruptcy value be calculated by treating as unsecured the secured claims with respect to which the creditor was nonadjusting. The extra amount received by the nonadjusting creditor under the adjustable-priority rule (relative to what it would have received under full priority) would come solely at the expense of the secured

160. Under U.S. bankruptcy law, certain "priority" unsecured creditors-such as the government and employees of the debtor-are entitled to have some or all of their claims paid ahead of those of general unsecured creditors. See supra note 16. However, for ease of exposition, we continue to assume in our examples that all unsecured creditors are treated equally in bankruptcy. 
claims with respect to which it was nonadjusting. Adjusting creditors would receive what they would have received under the rule of full priority. ${ }^{161}$

In this example, Bank's claim would be treated as unsecured when applying the rule of full priority to determine the nonadjusting creditor's bankruptcy share. As a result, in this example, the nonadjusting creditor would be entitled to receive $\$ 400,000$. The $\$ 300,000$ difference between what the nonadjusting creditor would have received under the rule of full priority $-\$ 100,000$ - and what it would receive under the adjustable-priority rule- $\$ 400,000$ - would come at the expense of Bank's secured claim. The adjusting creditor would receive what it would have received under full priority $-\$ 100,000$ and the Bank would receive the balance- $\$ 700,000$.

Since the adjustable-priority rule would ensure that the use of a security interest would not affect the nonadjusting creditor's share of bankruptcy value, it would prevent the security interest from being used to transfer bankruptcy value from nonadjusting creditors. Thus, such a rule, if it could be implemented fully, would eliminate the inefficiencies we identified as arising out of full priority: the use of inefficient security interests, the distorted choice between covenants and security interests, the increased distortions in the borrower's investments and level of precaution, and the suboptimal use and enforcement of covenants.

To illustrate the ex ante incentives created by the adjustable-priority rule, let us return to the example used in Section V.B to illustrate the problem of distorted choice between security interests and covenants. Recall that Bank and Firm will choose either a set of covenants or a security interest (but not both) to reduce Firm's ability to engage in inefficient asset dilution after Bank extends $\$ 1$ million of credit to Firm. Firm also borrows $\$ 1$ million from an adjusting creditor and $\$ 1$ million from a nonadjusting creditor. If Bank is given a security interest under full priority, $\$ 1.2$ million of assets will be available to be distributed to creditors in the event of default ( $\$ 1$ million of which will satisfy Bank's secured claim). However, if Bank uses a set of covenants designed to prevent Fiŕm's shareholders from engaging in inefficient asset dilution, $\$ 1.5$ million will be available to creditors in the event Firm fails. Recall that both the set of covenants and the security interest would impose the same contracting and opportunity costs on Bank and Firm, and that there is a $5 \%$ chance that Firm will fail in any event. Thus, as explained, adoption of the set of covenants would be more efficient because, in the event of bankruptcy, creditors would be $\$ 300,000$ better off than if the security interest were used, while shareholders would be no worse off (before interest is paid).

161. In principle, the adjustable-priority rule could be modified to reallocate the value between secured and adjusting creditors since bankruptcy transfers between secured and adjusting creditors would not give rise to any of the inefficiencies identified in Part V. 
However, we saw that, under the full-priority rule, Bank would receive $\$ 1$ million and the adjusting creditor would receive $\$ 100,000$ in the event of bankruptcy if the security interest were adopted, while those same two creditors would receive a total of only $\$ 1$ million if the covenants were adopted. Thus, Bank and the adjusting creditor would charge Firm less in interest if the security interest were adopted. As a result, under the rule of full priority, Firm and Bank would have an incentive to create the security interest rather than the set of covenants.

Now let us consider Firm's incentives under the adjustable-priority rule. If Firm issues the security interest rather than the covenants under the adjustable-priority rule, the nonadjusting creditor would receive $\$ 400,000$ in the event of bankruptcy - the amount it would have received under the fullpriority rule had Bank's claim been unsecured. ${ }^{162}$ Since the nonadjusting creditor would have received only $\$ 100,000$ under full priority, the adjustablepriority rule would increase its share by $\$ 300,000$. This comes at the expense of Bank, which would therefore receive only $\$ 700,000$. The adjusting creditor would still receive $\$ 100,000$. Thus, Bank and the adjusting creditor would receive a total of $\$ 800,000$ if the security interest were adopted, and therefore charge Firm more interest than if Firm had given the set of covenants. Firm and Bank would therefore have an incentive to choose the set of covenants over the less efficient security interest under the adjustable-priority rule.

While a partial-priority rule giving secured claims priority only over adjusting claims has never, to our knowledge, been proposed, a growing number of commentators have proposed that tort claims be given superpriority over secured claims in bankruptcy. ${ }^{163}$ The goal of these proposals has been to increase the incentive for commercial borrowers to reduce harmful externalities. As we explained in Section V.C, the ability of a borrower to subordinate tort creditors' claims by issuing security interests under a rule of full priority allows it to internalize less of the cost it imposes on these parties than it would under a pro rata rule. Superpriority would force borrowers to internalize even more of these tort costs than would a pro rata rule, and presumably would lead borrowers to take even more precautions and choose even better projects.

However, even if superpriority for tort claims were the best method for addressing the problem of tort externalities, which may or may not be the

162. Both the nonadjusting and the adjusting creditors' $\$ 1$ million claims are unsecured. Treating Bank's $\$ 1$ million claim as unsecured thus entitles the nonadjusting creditor to one-third of the $\$ 1.2$ million in assets, or $\$ 400,000$.

163. See, e.g., Barry E. Adler, Financial and Political Theories of American Corporate Bankruptcy, 45 STAN. L. REV. 311, 340 (1993); Leebron, supra note 91, at 1650; LoPucki, supra note 8. at 1907-08; Painter, supra note 91, at 1080-81; Roe, supra note 27, at 227. 
case, ${ }^{164}$ the scheme would at best somewhat reduce, and certainly not eliminate, the efficiency problems that are caused by full priority. As explained, the efficiency costs of according full priority to secured claims arise because of the existence of nonadjusting creditors, primarily voluntary creditors and government tax and regulatory agencies. Giving superpriority to tort claims would immunize tort creditors from the effects of priority, thereby reducing the efficiency costs we identified to the extent that they are caused by the presence of tort creditors. However, unlike the adjustable-priority rule, such a scheme would not reduce the distortions and efficiency costs to the extent that they are caused by the presence of contractual nonadjusting creditors and government tax and regulatory claims. ${ }^{165}$

To be sure, whether or not the adjustable-priority rule is worth adopting would depend in part on whether it could be administered in practice. Complete elimination of the inefficiencies that we show arise from full priority would require identifying during the bankruptcy proceeding those creditors that were adjusting and those creditors that were nonadjusting with respect to the various security interests issued by the debtor. Since it would clearly not be feasible to determine whether each creditor had in fact "adjusted" to each particular security interest, the adjustable-priority rule could never completely eliminate the identified inefficiencies.

Nevertheless, it would be possible to implement a version of the adjustable-priority rule that would significantly reduce the inefficiencies we identify. Many creditors that are nonadjusting with respect to a particular security interest are easily identifiable: (1) those creditors that had extended credit before the creation of the security interest and lacked an adjustment mechanism in their loan contracts with the debtor; (2) tort creditors; (3) government tax and regulatory agencies; and (4) such creditors as employees, customers, and utilities that are not in the business of lending, were not able to take the existence of particular security interests into account when contracting with the debtor, and in fact did not negotiate any credit terms with the debtor. In addition, nonadjusting treatment could be automatically accorded to all creditors with claims below a fixed, low threshold-say, $\$ 10,000$ or $\$ 25,000$. Creditors with such small claims will be rationally nonadjusting even if they are commercially sophisticated because it would generally not be

164. See Susan Block-Lieb, The Unsecured Creditor's Bargain: A Reply, 80 VA. L. REV. 1989. 1994-97 (1994) (questioning superpriority for tort claims on grounds that making secured creditors liable for these claims may not be most efficient method for reducing harmful externalities by firm).

165. One commentator who has advocated superpriority for tort claims has extended that proposal to deny a secured claim priority over the claims of any voluntary creditors that did not expect to be subordinated by that claim. See LoPucki, supra note 8, at 1913, 1947-48. Since there are many nonadjusting creditors that expect to have their claims subordinated in bankruptcy-such as the government, trade creditors, and prior creditors with large clains-such a proposal (assuming that it could be implemented) would fail to eliminate the problem of creditor nonadjustment and the resulting efficiency problems we analyze. 
worthwhile to conduct a detailed investigation of the financial structure of a borrower before extending such a small amount of credit. ${ }^{166}$ A "limited" adjustable-priority rule such as this would substantially reduce the inefficiencies identified in Part V at little administrative cost. ${ }^{167}$

However, even if a limited adjustable-priority rule could substantially reduce the efficiency costs associated with full priority, one may nevertheless believe that such a rule would be undesirable because of the uncertainty it would create for secured creditors. It is therefore worth considering a partialpriority rule in which secured creditors know with reasonable certainty what they will receive in bankruptcy, such as the fixed-fraction rule presented below.

\section{B. The Fixed-Fraction Priority Rule}

We now turn to examine the second partial-priority rule we present as an alternative to full priority: the fixed-fraction priority rule. Under this rule, a fixed fraction of a secured creditor's secured claim would continue to be treated as a secured claim, and the remainder would be treated as an unsecured claim. Thus, under a $75 \%$ fixed-fraction rule, $75 \%$ of a secured claim would be given full priority over unsecured claims, and the remaining $25 \%$ would become an unsecured claim.

A variant of the fixed-fraction priority rule was in fact proposed by the German Commission on Bankruptcy Law in 1985 as a replacement for the rule of full priority in German bankruptcy law. ${ }^{168}$ That proposal recommended that secured creditors be given only $75 \%$ of the amount of their secured claims collateralized by personal property. One of the justifications for the proposed rule was that, as our analysis demonstrates, exposing secured creditors to increased risk of loss is likely to encourage more desirable monitoring of their borrowers. ${ }^{169}$ Although the new German Insolvency Law (Insolvenzordnung) passed in 1994 did not include this $75 \%$ rule, it did incorporate several new

166. See supra Subsection IV.C.3.

167. One might worry that using a bright-line rule to distinguish between adjusting and nonadjusting creditors would distort loan transactions by causing lenders to limit inefficiently the size of their loans for the purpose of obtaining nonadjusting treatment in bankruptcy. There are three reasons why such distortions are not likely to occur. First, since the likelihood that a borrower will fail is usually rather small, a creditor will generally lose much more by limiting the size of its loans to $\$ 10,000$ or $\$ 25,000$ (either in foregone interest as a lender, or in foregone profit as a financing seller) than it will gain, on an expected-value basis, from achieving nonadjusting treatment in bankruptcy. Second, relying on small loan transactions would increase transaction costs for both borrowers and lenders. Third, borrowing from creditors that are treated as nonadjusting in bankruptcy would simply cause secured creditors to charge higher interest rates to the borrower (since their position in bankruptcy will be worsened to the extent that there are nonadjusting claims). Consequently, neither borrowers nor creditors would appear to have much incentive to distort their loan transactions in order to obtain favorable treatment under a bright-line rule.

168. See Drukarczyk, supra note 1, at 205.

169. Id. The other justification for the proposed rule was that it was unfair to fully subordinate the claims of unsecured creditors since personal property liens in Germany are difficult to discover. Id. 
features that will have the effect of reducing the priority of secured claims in German bankruptcy proceedings. ${ }^{170}$

To illustrate the operation of the fixed-fraction partial-priority rule, we will consider the version in which the secured creditor receives full priority with respect to $75 \%$ of its secured claim. Assume again that when Firm goes bankrupt it has $\$ 1.2$ in assets and owes $\$ 1$ million each to Bank, an adjusting creditor, and a nonadjusting creditor. As in the example used to illustrate the operation of the adjustable-priority rule, Bank has a security interest with respect to $\$ 1$ million of Firm's assets.

Under the $75 \%$ fixed-fraction priority rule, Bank would receive $\$ 750,000$ of the encumbered assets. The remainder of its claim, $\$ 250,000$, would be made unsecured and pooled with those of the other two creditors. The $\$ 450,000$ in assets available to pay unsecured claims would then be distributed to the three creditors in proportion to their unsecured claims, so that unsecured claims would be paid $20 \phi$ on the dollar. Bank would receive $\$ 50,000$ for its unsecured claim, and the others would receive $\$ 200,000$ each. In this example, the nonadjusting creditor would receive $\$ 200,000$ under the $75 \%$ fixed-fraction priority rule, $50 \%$ less than the $\$ 400,000$ it would receive under the adjustablepriority rule, but twice as much as the $\$ 100,000$ it would receive under full priority.

Like the adjustable-priority rule, the fixed-fraction priority rule would reduce the ability of creditors and their commercial borrowers to use security interests to transfer value from nonadjusting creditors by preventing secured claims from fully subordinating nonadjusting claims in bankruptcy. The fixedfraction priority rule would therefore also decrease the inefficiencies identified in Part V. The reduction of these distortions would depend on the percentage of the secured claim that is treated as unsecured: The larger the percentage, the greater would be the reduction in the identified inefficiencies. Eliminating the inefficiencies altogether would thus require treating the entire secured claim as unsecured.

Although a rule such as the $75 \%$ fixed-fraction rule would reduce but not eliminate the inefficiencies identified in this Article, it might be preferable to

170. Under the previous German bankruptcy law, many categories of secured creditors were effectively bankruptcy-proof by virtue of their ability to recover their collateral at any time during the bankruptcy proceeding. By contrast, the new Insolvency Law permits a bankruptcy administrator to apply for permission to use a secured creditor's collateral for the benefit of the estate (and its other creditors). See EUROPEAN CORPORATE INSOLVENCY, supra note 42, at 185-86; Anton Burger \& Bernhard Schellberg, The "Insolvency Plan" in the New German Insolvency Law, 11 TOLLEY's INSOLVENCY L. \& PRAC. 8, 11 (1995). Under the law, secured creditors may also be required to pay to the estate up to $6 \%$ of the proceeds they receive from the sale of the collateral. See EUROPEAN CORPORATE INSOLVENCY, supra note 42, at 186.

It is also worth noting that, in 1982, the United Kingdom's Cork Commission proposed an even more limited version of the fixed-fraction priority rule under which $10 \%$ of the property subject to floating charges (such as inventory) would be made available to pay unsecured claims. See Goode. supra note 1. at 66-67. The Cork Commission's proposal, which was never adopted. apparently was motivated exclusively by faimess and distributional concerns. See id. 
the adjustable-priority rule because it would create less uncertainty for secured creditors and would be somewhat easier to administer. And, as we explain in the next section, a fixed-fraction priority rule would certainly be preferable to the currently prevailing de facto rule of partial priority.

\section{The Existing Erosion of Priority}

While in principle U.S. bankruptcy law accords full priority to secured claims in bankruptcy, in practice, secured claims currently often receive less than full priority. It therefore might be argued that if partial priority were preferable to full priority, there would be no need to modify the existing regime. However, even assuming that the degree of partial priority faced by secured creditors in the existing bankruptcy regime were appropriate, the system currently achieves partial priority in a manner that is clearly undesirable.

Erosion of full priority under the existing regime works primarily through Chapter 11, where the focus is not on preserving state-law entitlements, but on encouraging the parties to agree to a reorganization plan that will enable the debtor to continue operating. ${ }^{171}$ If an insolvent firm does not liquidate immediately under Chapter 7, but rather first seeks to reorganize its capital structure under Chapter 11, a number of aspects of Chapter 11 will tend to reduce the value of a creditor's secured claim. A full description of how Chapter 11 undermines the priority of secured claims is beyond the scope of this Article, but the following discussion highlights the key features of Chapter 11 that lead to this result.

Under black-letter bankruptcy law, a secured creditor is entitled to receive interest on its secured claim $^{172}$ and any income generated by the collateral ${ }^{173}$ during the proceeding only to the extent that the value of its collateral exceeds the amount of the claim. Thus, the secured creditor is not always compensated for the time-value of its money during the Chapter 11 proceeding, which typically takes a year and a half or more. ${ }^{174}$

In principle, the court must provide "adequate protection"175 of a secured creditor's interest in the collateral throughout the proceedings. If the debtor's assets fall in value and the debtor is eventually liquidated, however, the secured creditor may receive less than the value of its collateral as measured at the time the bankruptcy petition was filed. In fact, since keeping bankrupt

171. See Rogers, supra note 8, at 975; White, Recent Erosion, supra note 23, at 399.

172. See 11 U.S.C. $\$ 506(b)$ (1994).

173. See United States Sav. Ass'n v. Timbers of Inwood Forest, 484 U.S. 365. 372-73 (1988): DOUGLAS G. BAIRD. THE ElEMENTS OF BANKRUPTCY 204-05 (1993).

174. See Baird. supra note 17. at 916 (citing Lynn M. LoPucki. The Trouble with Chapter 11. 1993 WIS. L. REV. 729, 739-45).

175. See supra note 14 and accompanying text. 
businesses in operation is costly, it is common for the debtor's assets to be worth substantially less at the end of a failed reorganization proceeding. ${ }^{176}$

Finally, if the debtor emerges from Chapter 11, the secured creditor will generally not be allowed to take physical possession of the collateral. Bankruptcy law requires only that the secured creditor be paid off with a note promising cash payments with a present value of at least the value of the secured creditor's interest in the collateral. ${ }^{177}$ However, bankruptcy judges will often choose an artificially low discount rate for the payments or undervalue the collateral (in order to reduce the debt and interest burden on the debtor emerging from bankruptcy), thus forcing the secured creditor to accept less than the full value of its secured claim. ${ }^{178}$ Commentators generally believe that the cumulative effect of these rules and practices is to divert value from secured creditors to both unsecured creditors and equityholders. ${ }^{179}$

Even assuming that the erosion of priority is optimal under the current regime, there are three significant problems associated with the way in which the erosion is achieved. First, whether and to what extent the secured creditor's priority claim is undermined under the current regime depend on such extraneous factors as whether the debtor decides to immediately liquidate under Chapter 7 or spend time in Chapter 11, the amount of excess value in the collateral, and the particular preferences of the bankruptcy court overseeing the case. The priority of secured claims is thus undermined in an arbitrary and unpredictable way, creating unnecessary uncertainty $e x$ ante for all creditors.

Second, the degree of erosion is not fixed by statute, but rather determined by the course of the bankruptcy proceedings. The participants in the reorganization thus have an incentive to use the proceedings strategically to maximize their respective shares of the bankruptcy pie. The struggle over the division of bankruptcy value frequently interferes with the ongoing operations of the debtor firm, leading to efficiency losses. ${ }^{180}$ Thus, partial priority is currently achieved at the expense of efficiency in bankruptcy.

Finally, under the current regime, some of the value diverted from secured creditors may well end up in the hands of shareholders. Transferring the value from secured creditors to shareholders in bankruptcy does not reduce the ability of these parties to divert value from nonadjusting creditors. Thus, such a transfer of value does not generate any of the efficiency benefits that we show would result from transferring bankruptcy value to nonadjusting creditors. Indeed, it is believed that the redistribution of value from creditors as a group to shareholders in bankruptcy actually exacerbates the tendency of shareholders to engage in inefficient and risky behavior before bankruptcy by

176. See Baird, supra note 17 , at 916 .

177. See 11 U.S.C. $\$ 1129$ (b)(2)(A) (1994).

178. See Baird, supra note 17 , at 915 .

179. See, e.g., Weiss, supra note 41 , at $77-78$.

180. See Bebchuk \& Chang, supra note 25, at 264; Franks \& Torous, supra note 25 , at $747-48$. 
reducing the cost to them of failure. ${ }^{181}$ Both the arbitrariness and the incentives to engage in inefficient behavior that are associated with the existing erosion of priority thus make the current bankruptcy regime a poor vehicle for implementing partial priority.

\section{The Cost And Effectiveness of a Partial-Priority RUle}

We have seen that the rule of full priority is associated with a number of efficiency costs and that a partial-priority rule would be able to reduce or eliminate those costs. However, a rule of partial priority would give rise to its own set of costs that must be analyzed before a final determination can be made that partial priority should be adopted. In this part, we accordingly begin such an analysis. Section VII.A offers a preliminary examination of the efficiency costs associated with partial priority. The results of this examination suggest that the efficiency costs of a partial-priority rule may not be substantial. Section VII.B then shows that the actual practices of sophisticated creditors and their borrowers support our view that partial priority is likely to be desirable. In Section VII.C, we demonstrate that a partial-priority rule could be sufficiently enforced to be made effective.

\section{A. The Efficiency Costs of Partial Priority}

In Part III, we identified the priority-independent costs and benefits of security interests. In Part V, we examined three priority-dependent costs of security interests and showed that inefficient security interests will be used when full priority is accorded to secured claims in bankruptcy. We now turn to examine the benefits that arise only to the extent secured claims are accorded priority in bankruptcy over unsecured claims. A rule of partial priority will give rise to efficiency costs by reducing these benefits, and the magnitude of these costs must be ascertained before a final determination can be made that partial priority is superior to full priority.

To our knowledge, the secured-debt literature describes only three prioritydependent efficiency benefits of security interests. These are the ability of security interests, when secured claims are accorded priority, to:

(1) reduce the information-acquisition costs of secured creditors;

(2) reduce monitoring-coordination costs when a borrower has a number of sophisticated creditors; and

(3) facilitate the financing of desirable activities.

181. See LuCIAN A. Bebchuk. THE EFFECTS OF Chapter 11 AND DEBT RENEGotiation on Ex ANTE Corporate Decisions 2-3 (Harvard Law School Program in Law and Economics Discussion Paper No. 104, 1991). 
The preliminary analysis we offer below indicates that these benefits-and the cost of reducing them-are likely to be rather modest.

\section{Increased Information-Acquisition Costs}

Under the rule of full priority, a security interest allows a secured creditor to extend credit at an appropriate interest rate that fully compensates it for the costs it incurs in lending to the borrower, without expending significant resources to acquire information about the borrower's probability of default and the expected value of the creditor's share of the borrower's bankruptcy assets. ${ }^{182}$ If the value of the assets subject to the secured creditor's security interest is greater than the amount due under the loan, including accrued interest and collection costs, the rule of full priority ensures that, in principle, the secured creditor faces no risk of loss in lending to the borrower. Thus, the creditor need not calculate its expected loss in order to extend credit to the borrower at the proper interest rate.

Under either of the two partial-priority rules considered, a secured creditor would be exposed to risk of loss, even if its claim were fully secured. Thus, the secured creditor-if its claim were large enough-would have an incentive to incur costs acquiring information about the borrower before it extended credit to ensure that its interest rate would fully compensate it for the risk of loss from lending to that particular borrower. Thus, the transaction costs associated with the extension of secured credit would be higher under partial priority than under a rule of full priority.

The extent of the information-acquisition costs under partial priority would of course depend on the particular partial-priority rule adopted. Under the $75 \%$ fixed-fraction priority rule, a secured creditor could anticipate receiving at least $75 \%$ of the value of its secured claim by the end of the bankruptcy proceeding. The secured creditor thus could set a reasonably appropriate interest rate simply by estimating the probability of the borrower's default. In contrast, use of the adjustable-priority rule might require a secured creditor to estimate the probability of the borrower's default, the amount of both nonadjusting and adjusting claims against the borrower, and the amount of the borrower's bankruptcy assets in order to set a proper interest rate. The increase in information-acquisition costs borne by secured creditors would therefore be smaller under the $75 \%$ fixed-fraction rule than under the adjustable-priority rule.

However, providing secured creditors an incentive to acquire more information about the riskiness of their borrowers' activities may well be socially desirable. As we explained in Part V, the ability to use secured debt under a rule of full priority to externalize further the cost of firms' activities

182. See Buckley, supra note 23 , at 1421-22. 
increases the incentive of shareholders to engage in risky activities and take insufficient precautions. To the extent that a partial-priority rule would cause the interest rates charged by secured creditors to reflect firm risk more accurately, the partial-priority rule would force shareholders to internalize more of the cost of their firms' activities. The adjustment of secured creditors' interest rates would thus cause these borrowers to act more efficiently. ${ }^{183}$ If the increase in information-acquisition costs is less than the gain in efficiency that results from forcing borrowers to internalize more of the cost of their activities, then, on balance, it would be desirable for secured creditors to incur the higher information-acquisition expenses to accomplish that result. ${ }^{184}$

\section{Increased Cost of Coordinating Monitoring Efforts Among Creditors}

We now consider the second priority-dependent efficiency benefit of security interests: the ability of a security interest under the rule of full priority to permit multiple creditors to coordinate their contractual control ("monitoring") of a borrower. Commentators have offered three explanations as to how a security interest giving a creditor full priority in certain assets of the borrower may be able to facilitate a more efficient level of monitoring by creditors. All of these explanations begin with the premise that there may be inefficient overmonitoring or undermonitoring if a botrower leaves all of its sophisticated creditors unsecured.

The first explanation is that a borrower may be able to reduce overmonitoring under the rule of full priority by giving a security interest to the creditors least capable of monitoring it, while leaving the creditors most capable of monitoring the borrower unsecured. According to this explanation-the "relative-skill theory"-providing security to the least capable monitors should reduce or eliminate their risk of loss and thus their need to engage in monitoring, while shifting the risk (and therefore the incentive to monitor) to the most capable (i.e., most cost-effective) creditors; the borrower is able to reduce its overall interest expense by relieving the least cost-effective creditors of the need to monitor. ${ }^{185}$

An alternative explanation-the "specialization theory"-is that a borrower may be able to reduce the overmonitoring that would result from leaving all

183. To the extent that the interest rate on a secured loan reflects the riskiness of the borrower's activities, the borrower will have more of an incentive to take precautions and choose less risky projects before the secured credit is extended and to agree to restrictions on its activities during the term of the loan.

184. It should also be noted that the owners of a firm seeking secured credit might be able to reduce substantially the information-acquisition costs borne by a secured creditor under partial priority by offering guarantees to the creditor secured by their own real or personal property. In fact, it is currently common for owners of smail firms to offer their own property as collateral when these firms borrow from a sophisticated creditor. Such an arrangement is desirable because it reduces the information-acquisition costs of the sophisticated creditors while directly increasing the incentive of the owners to run their firms more efficiently.

185. See Jackson \& Kronman, supra note 23, at 1154-56; Levmore, supra note 23, at 58-59. 
creditors unsecured by using security interests to assign creditors the tasks of monitoring different assets. Securing these creditors with specific collateral might allow the borrower to reduce the cost of monitoring by permitting each creditor to focus on and develop an expertise in monitoring certain assets rather than the overall financial health of the borrower. ${ }^{186}$

Finally, it has been suggested that a borrower may be able to reduce the overmonitoring or undermonitoring that would result from having all of its creditors unsecured by giving one creditor a security interest in the borrower's most important assets-its "focal point" assets-the control of which would benefit all creditors by preventing the borrower from engaging in inefficient activities. According to this explanation-the "focal point" theory-the secured creditor monitors on behalf of all of the other creditors, and is compensated for its efforts with a priority interest in the borrower's assets. The other creditors rely on the secured creditor to police the borrower, reducing their interest rates because they need not expend resources monitoring the borrower. ${ }^{187}$

These monitoring-coordination theories have been criticized on various grounds. For example, commentators have pointed out that, while the "relative skill" theory would predict that borrowers would secure the creditors that were the least capable monitors, the sophisticated creditors are in fact the most likely creditors to be secured. ${ }^{188}$ The "focal point" theory, which suggests that unsecured creditors will lower their interest rates when a skilled monitor is given a security interest in the borrower's most important assets, has been challenged on the ground that unsecured creditors capable of monitoring will not rely on the monitoring of a secured creditor because at any time the borrower and the secured creditor may agree to transactions involving the collateral that make them better off at the expense of other creditors. ${ }^{189}$

However, even if security interests do provide a priority-dependent efficiency benefit by coordinating monitoring efforts by multiple creditors in certain situations, the magnitude of this benefit under full priority would not be significant. The presence of more than one monitoring creditor does, as these theories suggest, give rise to efficiency costs that the borrower would have an incentive to eliminate. Indeed, empirical evidence indicates that firms that borrow from more than one institutional lender pay higher rates of interest. ${ }^{190}$ However, borrowers apparently avoid these coordination costs by not borrowing from more than one such lender in the first instance. As we

186. See BAIRD \& JACKSON, supra note 3, at 324-28; Baird, supra note 102, at 57: Jackson \& Kronman, supra note 23, at 1154 n.45. Another version of this theory is that full priority allows secured creditors to specialize in monitoring a firm's assets while unsecured creditors monitor the general financial condition of the borrower. For a critical discussion of this theory, see Buckley, supra note 23, at 1442-45.

187. See Levmore, supra note 23 , at 54-57.

188. See Buckley, supra note 23, at 1441-42; Levmore, supra note 23, at 53; Schwartz, Security Interests, supra note 23 , at 11 n.28.

189. See Buckley, supra note 23, at 1442-43.

190. See Petersen \& Rajan. supra note 105. at 34. 
explained, the empirical data on the financing arrangements of small and medium-sized firms-the issuers of most commercial secured debt in the United States-show that these firms almost always have only one sophisticated creditor (e.g., a bank or finance company) that is capable of engaging in general monitoring of the firm. ${ }^{191}$ In other words, there is little need for whatever monitoring-coordination benefits are provided by security interests under full priority. Thus, even assuming that security interests could, in theory, provide a priority-dependent efficiency benefit by coordinating the monitoring activity of creditors, on an aggregate basis this benefit is not likely to be substantial.

Moreover, to the extent that security interests provide a priority-dependent efficiency benefit by coordinating the monitoring efforts of sophisticated creditors, the adoption of a partial-priority rule need not significantly reduce this benefit. An analysis of the effect of different partial-priority rules on the monitoring efficiencies that arise under these scenarios is beyond the scope of this Article. However, it is worth noting that if a debtor has two monitoring creditors-one secured, one unsecured-the use of a $75 \%$ fixed-fraction priority rule is unlikely to reduce dramatically the incentive of the secured creditor to police the collateral subject to its security interest, ${ }^{192}$ or to reduce the incentive of the sophisticated unsecured creditor to engage in general monitoring of the debtor. Consequently, a partial-priority rule might largely preserve whatever monitoring-coordination efficiency benefits are conferred by security interests.

\section{Reduced Financing for Desirable Activities}

Until now we have assumed that, whether or not secured claims are accorded full priority over unsecured claims in bankruptcy, the loan transactions we have studied would take place. However, a secured creditor is likely to charge a higher interest rate under a partial-priority rule than under the rule of full priority to compensate for the lower value of its bankruptcy claim. In such a case, the loan transaction may not go forward. Without the financing, the borrower may not be able to begin operating, continue its activities, or pursue a particular project that the secured loan is needed to finance. Thus, a number of commentators believe that an important benefit of full priority is that it permits the financing of desirable activities that otherwise could not be financed. ${ }^{193}$

191. See supra text accompanying notes $155-56$.

192. Cf. Baird, supra note 17 , at 919 (observing that reducing priority of secured creditor may not lead to efficiency loss from decreased monitoring). 515-20.

193. See, e.g., Harris \& Mooney, supra note 8, at 2033, 2037; Stulz \& Johnson, supra note 23, at 502, 
Those who believe that full priority is desirable because it reduces the interest expense borne by firms may be concerned that a rule of partial priority would prevent the financing of some efficient activities that a rule of full priority would facilitate. On closer inspection, however, this problem is likely to be much less serious than it may appear. In fact, as we explain, a partialpriority rule is more likely to prevent the financing of an inefficient activity than an efficient one.

To analyze the effect of different priority rules on the projects chosen by firms, let us first examine the simple case in which all of the creditors are perfectly adjusting. For example, assume that Bank and an adjusting unsecured creditor each lend Firm $\$ 1$ million, and that Bank is given a security interest. Suppose that under a rule of full priority Bank charges Firm $\$ 80,000$ in interest and the adjusting creditor charges Firm $\$ 120,000$ in interest, so that Firm owes a total of $\$ 200,000$ in interest. Under a rule of partial priority such as the $75 \%$ fixed-fraction rule, Bank would increase the interest it charges Firm because-everything else being equal-the expected value of its bankruptcy claim would be lower. Suppose, for example, that to compensate for the increased risk of loss under partial priority, Bank increases the interest rate it charges Firm to $\$ 90,000$. Thus, under partial priority, Firm would be required to pay Bank $\$ 10,000$ more in interest. However, the increase in Bank's risk of loss would be offset by an equal decrease in the adjusting creditor's risk of loss which will reduce the interest it charges Firm by $\$ 10,000$. As a result, the total interest payments faced by Firm would be the same under full and partial priority if all of the creditors other than Bank were perfectly adjusting.

In the real world, of course, many creditors-such as the government and tort creditors-will not charge a lower interest rate under partial priority than under full priority. Thus, the next step is to examine the effect of changing priority regimes under the assumption that many of a borrower's creditors will not adjust their interest rates to take into account the priority rule that is in place. For concreteness, let us assume that Firm borrows $\$ 1$ million from Bank and owes the government another $\$ 1$ million. As in the previous case, Bank will charge Firm $\$ 80,000$ in interest under full priority and $\$ 90,000$ in interest under partial priority. However, since the government is nonadjusting, the size of its claim will be the same under either rule. As a result, the total interest payments faced by Firm will be $\$ 10,000$ higher under a rule of partial priority. This example suggests that the commentators who have defended full priority are correct in concluding that full priority reduces the interest borrowers must pay.

Let us now consider the effect of the priority rule on the willingness of Firm's owners to undertake certain projects. Continuing with the example, suppose that the activity that Bank's $\$ 1$ million loan is required to finance would yield a benefit to Firm's shareholders equal to $\$ 85,000$. Recall that 
under the rule of full priority Bank would charge Firm only $\$ 80,000$ in interest. Thus, the shareholders would undertake the activity because they would be $\$ 5000$ better off. Under partial priority, however, the shareholders would forego the activity because Bank would charge them $\$ 90,000$ in interest. This example suggests that partial priority would in fact foreclose some activities permitted under full priority.

But let us examine the nature of the activities that are foreclosed under partial priority. One can see that it is the activities generating between $\$ 80,001$ and $\$ 90,000$ worth of benefits for Firm's shareholders that would take place under full priority but not under partial priority. Under full priority, these activities would generate a net benefit to shareholders of between $\$ 1$ and $\$ 10,000$ while compensating Bank for its risk of loss. However, since full priority increases the expected value of Bank's bankruptcy claim by $\$ 10,000$ (allowing it to reduce the interest charged Firm by $\$ 10,000$ ), full priority must reduce the expected value of the government's claims by $\$ 10,000$. Thus, moving to full priority would be inefficient because it would make nonadjusting creditors worse off by $\$ 10,000$ and shareholders better off by a lesser amount. In other words, the activities that are likely to be precluded under partial priority but would be facilitated under full priority are those that are inefficient. ${ }^{194}$

Indeed, it has been widely observed that, by transferring value from nonadjusting creditors, a security interest under full priority may permit the financing of inefficient activities after the extension of credit. ${ }^{195}$ It should be emphasized that this inefficiency is distinct from (and in addition to) the five inefficiencies identified in Part V, which would arise even if each of the activities of the borrower is value-increasing. Thus, a rule of partial priority would have an additional advantage over full priority by facilitating fewer undesirable activities.

To be sure, there is a special case in which the ability to transfer value from nonadjusting creditors may permit the financing of an efficient activity. That is the case in which the provision of additional financing to the borrower would increase the value of nonadjusting creditors' claims. In such a case, the efficiency gain from the financed activity may be less than the positive externality conferred on nonadjusting creditors. If this is true, shareholders will not be able to capture any of the efficiency benefits. As a result, they will not undertake the activity unless a sufficient amount of value can be transferred

194. Cf. LoPucki, supra note 8, at 1909 (arguing that reducing priority accorded to secured claims may reduce level of undesirable activity).

195. See Hudson, supra note 27, at 49; Daniel E. Ingberman, Triggers and Priority: An Integrated Model of the Effects of Bankruptcy Law on Overinvestment and Underinvestment, 72 WASH. U. L.Q. 1341, 1372 (1994); White, supra note 27, at 552, 562-63 (arguing that according full priority to secured claims may lead firm to undertake inefficient investments or to continue operating inefficiently when it should be liquidated). 
back from the nonadjusting creditors to make the activity worthwhile for the shareholders. It is possible that in such a situation, a full-priority rule would transfer enough value to shareholders that they would undertake the efficient activity-while a partial-priority rule would not.

To illustrate, suppose Firm is very likely to fail unless it receives additional financing. Assume that, if Bank were to lend on an unsecured basis, the additional financing would boost the value of nonadjusting claims by $\$ 10,000$ by increasing the probability that they will eventually be paid in full. Assume further that the efficiency gain from undertaking the project is $\$ 7000$. Bank would charge an interest rate that compensates it for its risk of loss. Thus, if Bank were to lend on an unsecured basis, $\$ 3000$ of the increase in value enjoyed by nonadjusting creditors would come at the expense of shareholders who therefore would not undertake the efficient project. Now suppose that under a partial-priority rule the additional financing would increase nonadjusting claims by only $\$ 8000$ (since, in the event of bankruptcy, nonadjusting creditors would be worse off than under a pro rata rule). In such a case, the shareholders would still not capture any of the efficiency gain and thus would not undertake the efficient project. Suppose, however, that under full priority the value of nonadjusting claims would increase only by $\$ 6000$. In such a case, shareholders would be able to enjoy $\$ 1000$ of the efficiency gain of the activity. As a result, they would have an incentive to pursue it.

Thus it is true that full priority may-in certain situations-facilitate efficient activities that would not otherwise take place. However, these situations will arise only when: (1) the activity to be financed would transfer value to nonadjusting creditors; (2) the efficiency gain generated by the activity would be less than the positive externality conferred on the nonadjusting creditors; (3) the transfer of value from the nonadjusting creditors to the shareholders will be sufficiently large under full priority to allow shareholders to capture some of the efficiency gain; and (4) the transfer of value from the nonadjusting creditors to the shareholders would not be sufficiently large under the alternative partial-priority rule to allow shareholders to capture some of the efficiency gain. Thus, it is believed that this type of situation is rather rare. ${ }^{196}$

Furthermore, when an efficient activity would otherwise not take place under partial priority because it would confer too great a benefit on nonadjusting creditors, those creditors may well find it in their interest to modify their contractual rights in order to reduce the size of the positive externality and permit the activity to take place. That is, when certain activities will not be financed under partial priority because the equityholders would capture too little of the benefit of the activities, the nonadjusting creditors

196. See, e.g., Triantis, Secured Debt, supra note 23, at 248-49. 
might agree to reduce the size of their claims (by, for example, forgiving part of their loans, subordinating their debt, or exchanging their debt for an equity interest) in order to induce the equityholders to undertake the project. They will be better off receiving full payment on their reduced claims than little or no payment on their full claims. Indeed, lenders in workouts are routinely observed agreeing to reduce the size of their claims, presumably in order to increase the likelihood of ultimately receiving full payment on the balance of their claims. ${ }^{197}$

\section{B. Some Relevant Empirical Evidence}

Having examined the various costs and benefits associated with security interests under full priority, we now take a look at the actual practices of sophisticated creditors and their borrowers. Although we are currently living in a de facto partial-priority regime, the behavior of sophisticated creditors and borrowers may be able to shed some light on whether, when secured claims are accorded priority, the use of security interests is generally efficient-that is, whether the priority-independent and priority-dependent benefits of security interests are generally greater than their priority-independent and prioritydependent costs. In fact, the data suggest that, when priority is accorded to secured claims in bankruptcy, the use of security interests is often inefficient. The practices of sophisticated creditors and their borrowers thus tend to support our view that a partial-priority rule may well be superior to the rule of full priority from the perspective of efficiency.

Sophisticated creditors often do not incorporate security interests into their loan agreements. ${ }^{198}$ Their failure to do so provides evidence that, when priority is accorded to secured claims in bankruptcy, the use of security interests is frequently inefficient. As we saw in Part IV, the use of a security interest permits a borrower to transfer bankruptcy value from nonadjusting creditors. Thus, the failure to use a security interest implies that the efficiency costs of the security interest that would have been borne by the borrower and the sophisticated creditor would have been greater than the efficiency benefits they would have enjoyed from the security interest plus the expected transfer

197. See, e.g., Stuart C. Gilson et al., Troubled Debt Restructurings: An Empirical Study of Private Reorganization of Firms in Default, 27 J. FIN. ECON. 315, 345-46 (1990).

198. The most direct evidence that sophisticated creditors do not always take security interests is that many companies borrow from sophisticated creditors on an exclusively unsecured basis. See Leeth \& Scott, supra note 4, at 387 (reporting that only about 50\% of small businesses with commercial bank loans in study provided assets of the business as collateral); see also James R. Booth, Contract Costs, Bank Loans, and the Cross-Monitoring Hypothesis, 31 J. FIN. ECON. 25, 40 n.10 (1992) (noting that few firms with public unsecured debt borrow from banks on secured basis); LoPucki, supra note 8, at 1925 n.148 (reporting Federal Reserve statistics on lending by commercial banks to the effect that only $42.7 \%$ of $\$ 41,2$ billion in short-term loans were secured and only $64.7 \%$ of $\$ 3.7$ billion in long-term loans were secured). 
of bankruptcy value. This in turn suggests that the use of a security interest in these cases would have been quite inefficient. ${ }^{199}$

However, the most compelling evidence that the use of security interests is often undesirable from the perspective of efficiency is the tremendously widespread use of negative pledge covenants in loan agreements. ${ }^{200} \mathrm{~A}$ negative pledge covenant is a provision in a loan agreement that severely limits the ability of a borrower to issue secured debt during the term of the loan. Such a covenant imposes a cost on a borrower's owners by limiting the borrower's ability-during the term of the loan-to offer another lender priority in its assets in exchange for a lower interest rate. At the same time, a negative pledge covenant provides a benefit to the unsecured lender by preventing the borrower from engaging in various activities that will have the effect of reducing the value of the lender's claim.

199. Although the current bankruptcy regime is one of de facto partial priority, see supra Section VI.C, it still permits a borrower to transfer a significant amount of value from nonadjusting creditors by issuing a security interest.

To be sure, the expected value of this transfer will be low if there is little likelihood that the borrower will default. Thus, one might suggest that the borrowers with respect to which sophisticated lenders do not take security interests are those that are the least likely to fail. If this were the case, the failure of a sophisticated lender to use a security interest might demonstrate only that a security interest would have been inefficient but not that the inefficiency would necessarily have been significant.

However, the widespread use of negative pledge covenants, see infra note 200 , indicates that sophisticated creditors do believe that even with respect to highly rated publicly traded firms, the risk of failure is sufficiently high to make it worth negotiating for a contract that ensures that their claims will not be subordinated in bankruptcy. Since the use of negative pledge covenants demonstrates creditor' concem about their standing in bankruptcy, it stands to reason that these creditors would place some value on the bankruptcy priority accorded by a security interest. Thus, the failure of a sophisticated creditor to use a security interest in any given case suggests that the efficiency cost of using the security interest might have been substantial.

Moreover, it is worth noting that a large portion of small firms-which are statistically more likely to fail than larger firms, see Edward I. Altman et al., Zeta ${ }^{T M}$ Analysis: A New Model to Identify Bankruptcy Risk of Corporations, 1 J. BANKING \& FIN. 29, 35-36 (1977) (reporting that bankruptcy risk decreases with firm size); Leeth \& Scott, supra note 4, at 392-borrow on a completely unsecured basis. see id. at 387 (reporting that almost $50 \%$ of small businesses in study do not provide business collateral for commercial bank loans); Trends Tracked in Banking Practices of Small Businesses, J. ACCT., Oct. 1987, at 36, 39 (reporting then-recent study indicating that $40 \%$ of small companies did not use any secured-credit services). These data confirm that even when the value of priority might be relatively high, sophisticated creditors and borrowers often find they are better off not using security interests, which strongly suggests that the use of security interests is often inefficient.

200. See Morey W. McDaniel, Are Negative Pledge Clauses in Public Debt Issues Obsolete?, 38 Bus. LAw. 867, 870-72 (1983). Negative pledge clauses are invariably incorporated into most unsecured term loans originated by banks, insurance companies, and other institutional lenders. Id. at 872 . There is also widespread use of negative pledge clauses by publicly traded firms issuing unsecured debt. See MARCEL KaHAN \& BRUCE TUCKMAN, PRIVATE vs. Public Lending: EvidenCE FROM COVEnants tbl. 2, at 9 (Harvard Law School Program in Law and Economics Discussion Paper No. 151, 1995) (in sample of privately placed debt issues, $100 \%$ of investment-grade issues and $95 \%$ of junk bond issues contained limitations on issue of future security interests); Lehn \& Poulsen, supra note 148 (reporting that $49.6 \%$ of investment grade public bond issues and $46.1 \%$ of junk bond issues contained restrictions on ability of borrower to issue secured debt). A recent study found, in a sample of public debt issues rated A or higher, that over $90 \%$ of the issues restricted the borrower's ability to incur future secured debt. See Mai E. Iskandar-Datta \& Douglas R. Emery, An Empirical Investigation of the Role of Indenture Provisions in Determining Bond Ratings, 18 J. BANKING \& FIN. 93. 97-99 (1994). Indeed, a negative pledge clause is the only restriction found in many debentures. McDaniel, supra, at 870. 
A negative pledge covenant would not be used unless it makes both the borrower's shareholders and the unsecured lender better off. That is, the covenant must benefit the unsecured lender more than it costs the borrower's owners. Assuming that the unsecured lender and the borrower's owners were the only parties affected by the arrangement, the use of such a covenant would therefore indicate that it is efficient. Under these conditions, the use of the covenant would imply that it would be inefficient to create the security interests prohibited by its terms. The widespread use of these covenants would in turn mean that security interests are often inefficient.

However, the unsecured lender and the borrower's owners are not the only parties affected by the covenant. To the extent the borrower has other unsecured creditors, these creditors-since they are in the same position as the unsecured lender-will also derive benefit from the covenant. The share of the benefit derived by each of the borrower's unsecured creditors-including the unsecured lender that negotiated the covenant-will be in proportion to the size of its claim. In other words, if the unsecured lender supplies $60 \%$ of the borrower's unsecured credit, it will capture only $60 \%$ of the benefit of the covenant. The remaining $40 \%$ of the benefit will flow to the borrower's other unsecured creditors. As a result, one can infer from the use of a negative pledge covenant not only that such a covenant is efficient, but also that it is so efficient that just the share of the total benefit that is captured by the lender is greater than the cost borne by the borrower's owners. Thus, the frequent use of negative pledge covenants indicates that the creation of security interests is often very inefficient.

To be sure, both the failure of many sophisticated creditors to use security interests and the widespread use of negative pledge covenants in the United States takes place under the current de facto rule of partial priority. As we saw, certain efficiency benefits associated with security interests arise only to the extent that secured claims are accorded priority in bankruptcy. These efficiency benefits could, in theory, be significantly greater under a true fullpriority regime. The data thus cannot prove that the use of security interests would be inefficient as frequently under a true full-priority regime.

We also saw, however, that there are significant inefficiencies that arise when secured claims are accorded full priority in bankruptcy. These inefficiencies would be greater under a true full-priority regime than they are currently. Thus, the inference that can be drawn from current practices may actually understate the extent to which the use of security interests would be inefficient under a full-priority regime.

\section{Enforcement of Partial Priority}

Our analysis and the available data suggest that a rule of partial priority may well be more efficient than the rule of full priority. We now turn to the 
question of whether an explicit partial-priority rule such as the ones we propose could be enforced. There might be a number of ways in which a secured creditor and a borrower might try to evade the effects of a partialpriority rule. The specific options available to the secured creditor and the borrower would of course largely depend on the circumstances of the parties. Since most commercial secured debt in the United States is issued by smalland medium-sized companies, we will focus on two strategies that those borrowers and their secured creditors are likely to consider employing to evade a partial-priority rule. Our conclusion will be that a partial-priority rule could be made sufficiently effective to be worth adopting.

\section{1. "Opting Out" of Bankruptcy}

The most straightforward way for a secured creditor to evade a partialpriority rule would be to avoid participating in a bankruptcy proceeding. A secured creditor may seek to achieve this result either by seizing its collateral before the borrower enters bankruptcy or by having the borrower liquidate outside of bankruptcy.

Let us first assume that all failing firms eventually enter federal bankruptcy. As we explained in Part VI, neither of the two rules we present would affect a secured creditor's "repossessory right" or state-law "priority right." Under either of these two rules, a secured creditor's "repossessory right" and state-law "priority right" would remain intact while its secured claim would be accorded only partial priority in bankruptcy. The secured creditor will thus have an incentive to call a default and seize all of its collateral if it anticipates that the debtor will enter bankruptcy in order to avoid "sharing" its collateral with other creditors. If such a strategy were to succeed routinely, secured creditors could put themselves beyond the reach of the bankruptcy rules and undermine the efficiency benefits of using one of these partialpriority rules in bankruptcy.

However, the possibility is rather small that a secured creditor will succeed in "opting out" of partial priority by seizing its collateral before bankruptcy. The secured creditor would not be able to repossess unless the contract gives it the right, under the circumstances, to declare a default and seize the collateral. And, even if the creditor has the right to declare a default under the loan contract, its ability actually to seize the collateral will typically be limited. In particular, the secured creditor could not seize the collateral if by doing so it would breach the peace. ${ }^{201}$ Since commercial collateral is typically located on the borrower's property and cannot be accessed without its cooperation, this breach-of-the-peace restriction renders it very difficult for secured creditors to engage in "self-help" repossession from commercial borrowers. As a result, the 
secured creditor will almost always be required to turn to the slower judicial system in order to recover the collateral, providing the shareholders or the borrower's unsecured creditors (both of which will generally be better off if the borrower is in bankruptcy than if it is dismantled by the secured creditor outside of bankruptcy ${ }^{202}$ ) with ample time to file a bankruptcy petition.

More importantly, existing bankruptcy rules would generally make repossession by a secured creditor on the eve of bankruptcy futile. For example, section 547(b) of the U.S. Bankruptcy Code gives the bankruptcy trustee the right to void a transfer from the debtor to a creditor within ninety days of the filing of the bankruptcy petition if the transfer would give the creditor more than it would receive in a Chapter 7 liquidation. ${ }^{203}$ Indeed, under current law, unsecured creditors often force a firm into bankruptcy after the firm grants a security interest to another creditor, so that they can attack the transfer of the security interest under section $547 .{ }^{204}$ Since secured creditors are in principle entitled to the full value of their secured claims in Chapter 7, this provision is currently not invoked against fully secured creditors that receive payments from the debtor within ninety days of bankruptcy. However, under a partial-priority rule, the secured creditor would not be entitled to the full value of its claim in bankruptcy. Unsecured creditors (or the borrower) might respond to a repossession by forcing the borrower into bankruptcy within ninety days of the repossession and attacking the transfer under section 547 so that the value of the collateral could be used, at least in part, to satisfy their claims. Thus, even if a secured creditor could legally repossess its collateral, it might be reluctant to incur the cost of repossession knowing that unsecured creditors or the borrower would be likely to simply undo the repossession simply by filing a bankruptcy petition and attacking the transfer under section $547 .{ }^{205}$

We have seen that if all failing firms eventually entered federal bankruptcy, existing or slightly modified rules would generally prevent secured creditors from "opting out" of the bankruptcy proceedings. However, under current law, failing firms are not required to enter bankruptcy. Indeed, there are many firms that currently liquidate outside of bankruptcy. ${ }^{206}$ Thus, even if a partial-priority rule were adopted in bankruptcy, secured creditors whose borrowers liquidate outside of bankruptcy would still be able to enjoy full priority. The fact that many firms liquidate outside of bankruptcy might

202. Shareholders will generally be better off in bankruptcy because Chapter 11 holds out the possibility that they will be able to retain an interest in the reorganized firm. See Bebchuk \& Chang, supra note 25 , at 255 . Unsecured creditors will prefer bankruptcy because under a de facto partial-priority rule they will receive more than they would outside of bankruptcy.

203. 11 U.S.C. $\$ 547$ (b) (1994).

204. See LoPucki, supra note 8 , at 1927.

205. The preference period for transfers to secured creditors could of course be extended to six months or even one year if that were necessary to enforce a partial-priority rule.

206. See supra note 12. 
suggest that the effectiveness of a partial-priority rule in bankruptcy would be quite limited.

One could of course require that every liquidating firm with unpaid debt file a statement with the bankruptcy court listing its assets, transfers made during the preceding year, and the identities of all of its unpaid creditors. A court-appointed representative of the unsecured creditors or some other party could then supervise the allocation of the debtor's assets so that it conforms with the partial-priority rule in effect. Such a rule would completely eliminate any problem that would be posed by out-of-bankruptcy liquidations.

However, even without mandatory bankruptcy filing, a partial-priority rule in bankruptcy is likely to exert a significant influence on the behavior of borrowers and their creditors outside of bankruptcy. First, unsecured creditors with large enough claims will be able to threaten credibly to push a liquidating borrower into bankruptcy if they do not receive an amount reflecting what they would have received in bankruptcy under the partial-priority rule. Thus, secured creditors and unsecured creditors will have an incentive to allocate a liquidating borrower's assets outside bankruptcy in a way that mimics the prevailing bankruptcy priority rule. Indeed, it is believed that currently many firms liquidate outside of bankruptcy only after paying all of their debts or after paying creditors what the creditors expect to receive in bankruptcy. ${ }^{207}$

Second, at the time a secured creditor extends credit, the creditor will not know whether, if the borrower liquidates during the term of the loan, the liquidation will take place inside or outside of bankruptcy, and, if the liquidation takes place outside of bankruptcy, how much of the value of the collateral the secured creditor will be required to give up. Thus, even if there are cases where secured creditors are ultimately able to enjoy full priority outside of bankruptcy when a borrower liquidates without paying all of its debts, secured creditors will act as if they are in a partial-priority regime when negotiating loan agreements with their borrowers. As a result, a partial-priority rule in bankruptcy will tend to exert a desirable influence on the behavior of commercial borrowers and their creditors when they contract even if there is the possibility that the borrowers will liquidate outside of bankruptcy.

\section{Using Lease Arrangements to Evade Partial Priority}

Secured creditors may also seek to avoid a partial-priority rule by using arrangements that are similar to secured loans but which accord them more favorable treatment in bankruptcy. Indeed, a number of commentators have suggested that secured creditors can thwart any attempt to give them less than the full amount of their secured claims through the use of lease arrangements,

207. See Elizabeth Warren, Bankruptcy Policy, 54 U. CHI. L. REv. 775, 794 (1987). 
which can be functionally similar to secured loans but are currently not treated as such in bankruptcy. ${ }^{208}$

In a sale-leaseback transaction, a firm sells assets to another party and then leases them back. A standard lease agreement requires the firm to make periodic payments on the lease to the lessor, and gives the lessor the right to repossess the assets in the event of a default by the firm. At the termination of a typical lease, the assets may be either returned to the lessor or purchased by the firm. Depending on its terms, a lease may very closely resemble a secured transaction. In both cases, the firm has use of an asset, agrees to make a stream of payments to another party, and must relinquish possession of the asset if it defaults on its obligations. ${ }^{209}$

Under current bankruptcy law, leased assets are not property of the debtor and therefore do not enter the bankruptcy estate, ${ }^{210}$ meaning that their value is not available for distribution to creditors. Instead, the bankrupt firm may either assume the lease (after curing any existing defaults), or reject the lease and return the assets to the lessor. ${ }^{211}$ As a result, the lessor is assured of receiving either the assets or the contract payments after the lessee enters bankruptcy. In contrast, under a rule of partial priority, a secured creditor would receive only a portion of the value of the assets serving as its collateral.

Although firms and their sophisticated creditors would appear to be able to avoid partial priority by structuring secured transactions as leases, current law already makes it somewhat difficult for an arrangement that functions like a secured loan to be treated as a lease in bankruptcy. That is, bankruptcy law may consider an arrangement a secured loan for bankruptcy purposes even if it is labelled a "lease" by the two parties. There must be a real economic difference between a lease arrangement and a secured loan for the arrangement to be recognized as a lease under bankruptcy law. ${ }^{212}$ For example, the arrangement must not make the lessee bear the cost of depreciation, and the arrangement must terminate before the end of the asset's life. ${ }^{213}$

Thus, an arrangement that will be recognized as a lease in bankruptcy will not be a perfect substitute for a secured loan. And, to the extent the lease is in fact functionally different from a secured loan, it is likely to impose costs on the parties that a secured loan would not. For example, because the lessee does not bear the risk that the leased assets will fall in value by the end of the

208. See, e.g., White, supra note 17 , at 503.

209. A sale-leaseback is similar to a secured transaction in which a firm encumbers an existing asset to borrow cash. An ordinary lease is analogous to a purchase-money secured transaction in which the firm acquires a new asset that serves as collateral for the purchase price. Our analysis does not distinguish between these two types of lease arrangements.

210. See 11 U.S.C. $\$ 541$ (1994). However, the lease contract itself enters the estate through this provision.

211. See id. $\$ 365$.

212. See U.C.C. § 1-201(37) (1994); White, Recent Erosion, supra note 23, at 420.

213. See White, Recent Erosion, supra note 23, at 420. 
lease term, it has less incentive to properly use and maintain them. The lessor must thus impose restrictions on the assets' use and monitor the lessee's compliance, an arrangement that would be costly for both parties ${ }^{214}$ whether or not the lessee goes bankrupt. There are also other inherent costs to leasing. For example, the lessor may be required to operate a facility for maintaining and disposing the leased goods.

In addition, the current bankruptcy treatment of leases is not entirely favorable for the lessor. If the lessee enters Chapter 11, there may be a significant delay before the lessee rejects the lease and returns the assets to the lessor. ${ }^{215}$ And, whether the lessee is in Chapter 7 or Chapter 11, any damage claims arising from the lessee's rejection will be treated as an unsecured claim that arose before bankruptcy. ${ }^{216}$ Finally, a bankrupt lessee may be permitted to assign the lease to another party over the lessor's objections. ${ }^{217}$ Thus under partial priority there would be many cases where the expected cost of leasing is greater than the expected loss of lending on a secured basis; in those cases, the parties would not substitute a lease for a secured loan.

However, let us assume that current law permitted leases structured sufficiently like secured loans to be treated as leases in bankruptcy, and therefore that secured creditors under current law could simply switch to leasing to avoid the effect of a partial-priority rule. In such a case, the partialpriority rule could easily be enforced by modifying the treatment of leases in bankruptcy so that it was similar to that accorded secured loans. Indeed, to the extent that leases are similar to secured loans, there would appear to be no economic or other reason for treating the arrangements differently in bankruptcy. ${ }^{218}$ Thus, there would appear to be little cost to affording lessors less favorable treatment in bankruptcy if that were necessary to enforce a partial-priority rule.

In fact, because both leases and secured loans give the lender or lessor priority in bankruptcy, they are likely to give rise to the same types of inefficiencies. Indeed, the covenants issued by public companies typically place similar restrictions on borrowers with respect to both security interests and leases, ${ }^{219}$ suggesting that the two arrangements do in fact have similar undesirable efficiency consequences. Thus, according even less favorable

214. See generally Clifford W. Smith, Jr. \& L. MacDonald Wakeman, Determinants of Corporate Leasing Policy, 40 J. Fin. 895 (1985) (showing how various incentives explain use of contractual provisions in corporate leases).

215. A lessee in Chapter 11 may be permitted to delay deciding whether to "reject" or "assume" the lease until the end of the proceedings. See 11 U.S.C. $\$ 365(d)(2)(1994)$.

216. Id. $\& 365(\mathrm{~g})(1)$.

217. Id. § 365(f).

218. Cf. John D. Ayer, On the Vacuity of the Sale/lease Distinction, 68 Iowa L. REv. 667 (1983) (arguing that there is no justification for disparate treatment of leases and secured loans in bankruptcy since two arrangements are essentially identical).

219. See McDaniel, supra note 200 , at $867-68$. Indeed, the only restrictions found in the debentures of companies rated $\mathrm{A}$ or better are sale-leaseback restrictions and negative pledge covenants. Id. at 868 . 
treatment to the lessor in bankruptcy-for example, by allowing the bankruptcy estate to reduce its lease payment obligations-might be desirable even if it were not necessary to enforce partial priority. ${ }^{220}$

\section{FURTHER CONSIDERATIONS CONCERNING THE DESIRABILITY OF PARTIAL PRIORITY}

In this part, we consider other issues related to the desirability of adopting a mandatory rule of partial priority. Section VIII.A explains that an examination of the past behavior of U.S. firms is unlikely to indicate which priority rule is most efficient. In Section VIII.B, we show that giving firms a choice between partial priority and full priority is also unlikely to answer the question of which rule is more efficient. Section VIII.C shows that full priority is not required by bargain or fairness considerations. In Section VIII.D, we demonstrate that full priority is also not mandated by freedom of contract principles.

\section{A. Learning from the Past Behavior of U.S. Firms}

Our preliminary analysis of the possible efficiency costs of according less than full priority to secured claims suggests that those costs-informationacquisition costs, certain monitoring-coordination costs, and the loss from efficient activities that cannot be financed-are likely to be relatively modest. Indeed, some of the efficiency costs of partial priority may be necessary to achieve even greater efficiency benefits. The additional information that secured creditors are likely to acquire about their borrowers under partial priority will permit better control of their borrowers' behavior after credit is extended. And, while certain efficient activities that would have been financed under full priority may not take place under partial priority, certain inefficient activities may not take place as well. ${ }^{221}$

Since our analysis is preliminary and therefore cannot provide a definitive answer to the question of which priority rule is superior, one might consider investigating the actual behavior of firms to see if it could shed any light on the issue. In particular, it might be hypothesized that if a particular partialpriority rule were in fact more efficient than the full-priority rule, borrowers would privately contract with their creditors to be bound by that partial-priority

220. The priority currently accorded to lessors in bankruptcy undoubtedly distorts the parties' choice between efficient lending arrangements and less efficient leases. According less favorable treatment to lessors would tend to reduce this distortion. For another possible benefit of according lessors less favorable treatment in bankruptcy, see Jesse M. Fried, Executory Contracts and Breach Decisions in Bankruptcy 8 (Oct. 10, 1995) (unpublished manuscript, on file with author) (noting that reducing payments required of bankrupt debtor under lease would reduce problem of inefficient breach in bankruptcy).

221. See supra Subsection VII.A.3. 
rule. Since firms are in fact not observed establishing private partial-priority rule arrangements, one might be led to think that there is no rule of partial priority that is more efficient than the rule of full priority.

However, as we explained in Section VI.C, the de facto regime in which U.S. firms operate is not one of full priority. As a result of the workings of Chapter 11, secured creditors do not expect to receive, on average, the actual value of their secured claims. Thus, a U.S. firm seeking to be governed by a partial-priority rule would not need to opt out of U.S. bankruptcy law.

More importantly, firms do not have the ability to opt out of U.S. bankruptcy law; the bankruptcy rules are mandatory. ${ }^{222}$ Thus, even if a firm preferred to be governed by another rule (i.e., another partial-priority rule or a true full-priority rule), it could not choose such a regime. Consequently, the failure to observe firms opting out of U.S. bankruptcy law cannot be used as evidence for or against the efficiency of any particular rule.

\section{B. Leaving the Priority Rule to Private Ordering}

One might propose that U.S. firms be allowed to choose to be governed by either a full-priority or a partial-priority rule. Such an arrangement would appear to eliminate the need to determine the relative efficiency of the two rules, since each firm would presumably choose the regime that was most efficient given its particular circumstances.

However, if a firm were given the choice between a full- and a partialpriority regime, it is unlikely that it would choose the partial-priority regime even if that regime were more efficient. As explained, involuntary creditors, and in particular government agencies, are likely to have significant claims against the firm when it goes bankrupt. These creditors would not adjust the size of their claims against the firm to take into account the priority regime chosen by the firm. Thus, if the firm were to choose a partial-priority regime, secured creditors would demand higher interest rates, but involuntary creditors would not reduce the size of their claims (even though they would be better off). Unless the efficiency advantage of partial priority over full priority were greater than the value transferred from involuntary creditors by such a move, the firm would not have an incentive to choose partial priority. ${ }^{223}$

Even in the absence of involuntary creditors, a firm would choose a more efficient partial-priority regime only if it expected its voluntary unsecured creditors to charge lower interest rates than they would under a full-priority

222. See, e.g., United States v. Royal Business Funds Corp., 724 F.2d 12, 15 (2d Cir. 1983) (citing general rule that debtor may not agree to waive right to file bankruptcy petition): Rasmussen. supra note 32, at $61 \mathrm{n} .28$ (describing inability of firm to contract around Chapter 11 provisions).

223. Cf. Rasmussen. supra note 32, at 67 (observing that firms permitted to choose among bankruptcy regimes will have incentive to choose the one that assigns lowest possible priority to nonconsensual claimants). 
regime and thus compensate the firm for the higher rates that would be demanded by secured creditors. To induce voluntary unsecured creditors to lower their interest rates, it would be necessary for the firm to notify its creditors, including those with small claims, that the firm was a "partialpriority rule" firm rather than a "full-priority rule" firm.

However, notifying voluntary unsecured creditors-including such creditors as utilities and trade suppliers-is unlikely to be sufficient to induce creditors to calibrate their interest rates to the particular priority regime chosen by the firm. Trade suppliers currently charge uniform interest rates to all of their customers, indicating that they do not take into account the particular characteristics of each borrower. Given that the likelihood that any particular firm will go bankrupt is very small, that an individual trade supplier's bankruptcy payment may not differ much (in absolute terms) under a fullpriority and a partial-priority rule, and that the trade supplier's customers will differ considerably along many other dimensions that affect the creditor's risk of loss, there is no reason to believe that a creditor would take into account the priority rule in determining the interest rate. Instead, creditors with small claims could be expected to continue charging a single interest rate calculated to compensate them for the aggregate risk they face in lending to many different types of firms. ${ }^{224}$ As a result, firms might have little incentive to choose an efficient partial-priority regime even in a world with no involuntary creditors.

Given the expectation that even many voluntary creditors will not adjust the interest rate they charge to reflect the priority regime chosen by firms, allowing firms to choose between partial priority and full priority is unlikely to answer the question of which rule is socially optimal since their choice will be distorted in favor of full priority. This analysis further suggests that since firms may choose a full-priority regime over a partial-priority regime even if the partial-priority regime were more efficient, a partial-priority rule should be made mandatory rather than optional if it is believed to be the most efficient rule.

\section{Fairness and Bargain Considerations}

Our analysis thus far has focused on the rules of full and partial priority primarily from an efficiency perspective. From this perspective, we have shown that a rule of partial priority may well be preferable to the rule of full priority. But, before closing, it is worth considering whether some other normative principle can be seen as requiring the rule of full priority.

224. Cf. Baird, supra note 106 , at 2259 (observing that transaction costs of informing trade creditors, who generally charge uniform interest rates to all customers, that a particular borrower had amended its charter to create optimal financial structure would likely make such change not worthwhile). 
One might take the position that giving a secured claim less than full priority in bankruptcy is inconsistent with the bargain that the secured creditor makes with the borrower and is thus unfair. In particular, one might argue that since the secured creditor had contracted for full priority and had chosen its terms accordingly, that priority should be respected consistently by the law. Indeed, the legislative history of the current U.S. Bankruptcy Code states explicitly that it was the intent of the U.S. Senate, in drafting the bankruptcy laws, to give secured creditors the benefit of their bargains. ${ }^{225}$

However, the fairness or bargain argument for according full priority to secured claims in bankruptcy is less valid than it may appear at first glance. Under a partial-priority regime, creditors taking security interests would expect partial-priority treatment in bankruptcy (not full priority) and choose their terms accordingly. Providing them with only partial priority in the end would therefore be perfectly consistent with their initial bargain. That is, if a borrower of a secured creditor were to enter bankruptcy, the secured creditor would get no more and no less than it expected to receive in such an event. ${ }^{226}$ Indeed, given that the de facto regime has been one of less than full priority for some time, it is reasonable to assume that secured creditors currently expect to receive on average less than full priority for their secured claims in bankruptcy and set their terms to reflect that expectation. When a borrower enters Chapter 11 and a secured creditor receives less than the actual value of its secured claim, that secured creditor therefore cannot claim that it was treated unfairly.

Finally, it is worth noting that the transition to an explicit partial-priority rule need not deny secured creditors the benefit of the bargains they entered into before the change of regime. If necessary, the rule could be applied only prospectively. Of course, if the partial-priority rule adopted accorded as much priority to secured claims as those claims receive today under the de facto partial-priority regime, secured creditors that had extended credit before the change of regime would receive the benefit of their bargains. ${ }^{227}$

\section{Freedom of Contract Concerns}

Even if one believed that the adoption of a rule according partial priority to secured claims was not foreclosed by bargain or fairness considerations, one might still raise the objection that such a rule constrains freedom of contract.

225. See supra note 14.

226. Cf. Rogers, supra note 8, at 986-87 (arguing that Fifth Amendment takings doctrine does not apply to secured creditor whose state-law rights are modified in bankruptcy, because at time of entering arrangement secured creditor knew or should have known that its rights were circumscribed by federal bankruptcy law).

227. In contrast, if all existing debt were suddenly to become subject to a true full-priority regime, current secured creditors would get a windfall, and current unsecured creditors would not get the benefit for which they had bargained. 
In particular, one might argue that a partial-priority rule denies a borrower the right to grant a creditor a security interest giving the creditor full priority in the collateral under all circumstances. Indeed, the rule of full priority has been defended on just this ground. ${ }^{228}$

However, freedom of contract arguments have force only with respect to arrangements that do not create direct externalities. When a contract directly affects only the parties to that arrangement, in most cases it is believed that the parties should be allowed to choose for themselves whatever is best for them. But when the contract directly impinges on the rights of third parties, there is no prima facie presumption of freedom of contract. ${ }^{229}$

When an insolvent debtor enters bankruptcy, the bankruptcy court cannot enforce all of the contracts the debtor entered into before it defaulted; the assets available are simply insufficient to make this possible. As a result, the bankruptcy system must modify the debtor's loan contracts by limiting the extent to which each creditor is entitled to repayment. This is generally accomplished by giving each creditor a right to its pro rata share of the debtor's bankruptcy assets. ${ }^{230}$ In this setting, an arrangement between the debtor and a particular creditor that gives the creditor more than its pro rata share of the debtor's bankruptcy assets must therefore reduce, dollar-for-dollar, the amount that will be available to other creditors-that is, such an arrangement creates a direct externality on these other creditors.

Since an arrangement that allows the debtor to increase the bankruptcy share of one party must come at the expense of another, it is only natural that the law imposes restrictions on the ability of a debtor to enter into such arrangements. For example, a firm may not sell options on its bankruptcy value to noncreditors. ${ }^{231}$ The law also does not allow a debtor to favor some creditors at the expense of others by making preferential payments on the eve of bankruptcy. ${ }^{232}$ Nor, as we observed in Part II, does the law give any force to a contractual term between a debtor and unsecured creditor $C_{l}$ giving that unsecured creditor's claim priority over the claim of unsecured creditor $C_{2}$ in bankruptcy. The refusal of the law to enforce the sale of $C_{2}$ 's bankruptcy value to $C_{I}$ does not generally raise freedom of contract concerns because it is recognized that the debtor's sale of $C_{2}$ 's bankruptcy value to $C_{I}$ concerns the disposition of something of value that does not belong to either of them, but rather to $C_{2}{ }^{233}$ It would be no more natural for the law to enforce such a

228. See Harris \& Mooney, supra note 8 , at 2049-53.

229. Cf. Schwartz, Taking, supra note 23, at 2082 (arguing that contractual arrangement is considered presumptively desirable only if there are no externalities).

230. For discussions of the pro rata rule, see JACKSON, supra note 30. at 29-32; Kanda \& Levmore, supra note 23 , at 2122.

231. Cf. Buckley, supra note 23, at 1456-58 (questioning policy bases for prohibition of sales of bankruptcy value to noncreditors).

232. See 11 U.S.C. \$ 547 (1994).

233. See LoPucki, supra note 8, at 1899 \& n.52. 
contract than it would be to enforce a contract in which the debtor sells $C_{2}$ 's house to $C_{r}$.

However, under the rule of full priority, the creation of a security interest by a debtor in favor of $C_{I}$ accomplishes the same result as a contract between the debtor and $C_{l}$ that gives $C_{l}$ 's claim priority over $C_{2}$ 's claim. A security interest under full priority thus creates the same direct externality as a simple contract between the debtor and $C_{l}$ that the law would refuse to enforce. ${ }^{234}$ Freedom of contract no more requires that the debtor and $C_{l}$ be permitted to create a security interest subordinating $C_{2}$ 's claim than it requires that the law enforce a simple contract between $C_{I}$ and the debtor achieving the same result. Thus, while it may be desirable from an efficiency standpoint to fully or partially respect the priority of secured claims in bankruptcy, such a result is certainly not mandated by freedom of contract principles.

\section{CONCLUSION}

This Article has reexamined a basic principle of bankruptcy law-that secured claims should be accorded full priority over unsecured claims. We have taken issue with the view widely held by legal scholars and economists that economic efficiency is best served by giving secured claims full priority in bankruptcy. Our analysis has demonstrated that the rule of full priority in fact creates distortions in the contractual arrangements between commercial borrowers and their creditors, producing various efficiency costs. In particular, the Article has shown that full priority causes excessive use of security interests, reduces the incentive of firms to take adequate precautions and choose appropriate investments, and distorts the monitoring arrangements chosen by firms and their creditors.

Having identified the efficiency costs associated with full priority, we also have considered the desirability of a different approach-according only partial priority to secured claims. Our analysis of partial priority has shown that such a rule could eliminate or reduce these efficiency costs-and that such an approach may well be more efficient than the full-priority rule. Therefore, we have put forward two particular partial-priority rules-the adjustable-priority rule and the fixed-fraction priority rule-that should be considered as alternatives to the rule of full priority. Our analysis has also shown that a partial-priority rule should not be left to private ordering, could be feasibly implemented, and would be consistent with considerations of fairness and contractual freedom. We hope that our work will lead bankruptcy scholars to reconsider the principle of full priority, and that the framework of analysis we have developed will prove valuable in this effort. 